\author{
Dayseanne Araujo Falcão
}

\title{
DEFICIÊNCIAS CONCOMITANTES DA PROTEÍNA REGULADORA FATOR H E DO COMPONENTE C9 DO COMPLEMENTO
}




\section{Dayseanne Araujo Falcão}

\section{DEFICIÊNCIAS CONCOMITANTES DA PROTEÍNA REGULADORA FATOR H E DO COMPONENTE C9 DO COMPLEMENTO}

Tese apresentada ao

Instituto de Ciências Biomédicas da Universidade de São Paulo, para obtenção de Título de Doutor em Ciências (Imunologia). 


\section{Dayseanne Araujo Falcão}

\section{DEFICIÊNCIAS CONCOMITANTES DA PROTEÍNA REGULADORA FATOR H E DO COMPONENTE C9 DO COMPLEMENTO}

Tese apresentada ao Instituto de Ciências Biomédicas da Universidade de São Paulo, para obtenção de Título de Doutor em Ciências (Imunologia).

Área de concentração: Imunologia

Orientadora: Prof. Dra. Lourdes Isaac 


\section{UNIVERSIDADE DE SÃO PAULO \\ INSTITUTO DE CIÊNCIAS BIOMÉDICAS}

Candidato(a): $\quad$ Dayseanne Araujo Falcão.

Tese: Deficiências concomitantes da proteína reguladora Fator $\mathrm{H}$ e do componente C9 do complemento.

Orientador(a): $\quad$ Lourdes Isaac.

A Comissão Julgadora dos trabalhos de Defesa da Tese de Doutorado, em sessão pública realizada a ................................, considerou

( ) Aprovado(a) ( ) Reprovado(a)

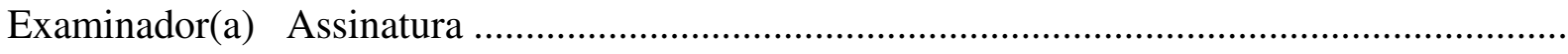

Nome

Instituição

Examinador(a) Assinatura .

Nome

Instituição

Examinador(a) Assinatura

Nome

Instituição

Examinador(a) Assinatura

Nome

Instituição

Presidente Assinatura

Nome

Instituição 


\begin{abstract}
A Tese de Doutorado intitulada "Deficiências Concomitantes da Proteína Reguladora Fator H e do Componente C9 do Complemento" foi desenvolvida no Laboratório de Complemento do Departamento de Imunologia do Instituto de Ciências Biomédicas da Universidade de São Paulo, com auxílio financeiro da Fundação de Amparo à Pesquisa do Estado de São Paulo (FAPESP) e do Conselho Nacional de Pesquisa e Desenvolvimento (CNPq).
\end{abstract}

-São Paulo- 


\section{Ao meu Deus}

Porque sem ELE eu sequer seria.

\section{Aos meus pais, Ruth e Nicodemos}

Porque diante da grandeza de vocês as palavras são infinitamente pobres, as expressões insuficientes e os gestos absolutamente dispensáveis. Juntos, as palavras, as expressões e os gestos silenciam, enquanto o exemplo de vida dado por vocês anuncia ao mundo o quanto sou abençoada por tê-los como pais. 


\section{Agradecimentos}

À Dra. Lourdes Isaac. Os anos ainda por vir da minha vida serão insuficientes para te retribuir tanta confiança, tanta dedicação, tanto apoio, a fim de que este grande dia chegasse. Muito mais do que orientadora e profissional exemplar você foi companheira, mãe e amiga. Nos momentos mais difíceis você sempre esteve lá, sempre! Lou, muito obrigada por tanto, tanto, tanto...

Ao Dr. Shaker Chuck Farah do Departamento de Bioquímica da USP por ser sempre alguém com quem pudemos contar em tantas dificuldades enfrentadas.

À Dra. Anete Grumach do Departamento de Dermatologia do Hospital das Clínicas, pelo encaminhamento do paciente e pela indispensável colaboração na obtenção de amostras e dados.

Aos Drs. José Alexandre Barbuto do Departamento de Imunologia da USP, Marcelo De Franco da Imunogenética do Instituto Butantã e Beatriz Carvalho da UNIFESP, pela análise e sugestões promovidas durante o exame de Qualificação, sempre acompanhadas de muito carinho, respeito e valorização deste trabalho. Muito obrigada, professores!

À Dra. Ises Abrahamson do Departamento de Imunologia da USP, por ter recebido de braços abertos em seu laboratório uma sergipana sem eira nem beira. Um dia você me deu um voto de confiança e, por isso, aqui estou. Obrigada, professora!

Às Dras. Gláucia Machado Santelli e Patrícia Gama pela paciência e inestimável colaboração na obtenção das imagens por microscopia confocal e fluorescência. A Luciana, por ter sempre tido tanta boa vontade e simpatia ao nos receber nesses momentos de captação de imagens.

A minha amada vovó Gláucia por uma vida de completa dedicação à família que construiu com tanto amor e competência. Aos meus amados irmãos, Nicodemos Jr., Delman, Neander, Miguel, Rejane e Bruno, pelo amor incondicional e por estarem sempre ao meu redor tentando remover as pedras que insistem em aparecer no meu caminho. As minhas tão queridas cunhadas, Sileide (Dão), Laura (Lídia) e Fabiana (Sabi) e Kátia (Kascas), porque 
vocês não têm idéia do quanto o amor de vocês me faz andar a segunda milha vida a fora. As minhas vidas, meus amados sobrinhos Sarah (Sassá, meu catatau), Nicole (Saborosa), Ester (Téca) e Yan (Zanzo), por serem sempre uma excelente razão pra voltar pra casa. Amo todos vocês!

Ao meu namorado, José Antônio, pelas tantas horas de companheirismo no laboratório, pelas sugestões, apoio e auxílio quando tentamos tantas vezes vencer os desafios diários da ciência. Mas mais ainda, por tanta cumplicidade, carinho e compreensão que me fazem sentir tão especial e tornam a minha vida muito mais completa e feliz.

Aos demais membros da minha enorme família, amados tios, tias e primos (especialmente Jardelzinho, Fuca, Cecéu, Nana, Éden), por serem uma parte tão importante de mim, por me amarem e protegerem desde o dia em que nasci e pela torcida e apoio pra que este grande dia chegasse. Amo todos vocês!

A amada Marlene, por tantos abraços carinhosos, pelos conselhos, por tanta paciência e compreensão, por não medir esforços para ajudar nas atividades do laboratório, por sempre colocar amor em tudo que faz, mesmo que seja um simples sorriso. Má, sem você a caminhada teria sido insuportável. Obrigada por você ter estado ao meu lado todo o tempo!

À amiga irmã, Edimara, por estar sempre pronta a dividir seus vastos conhecimentos, sua experiência, por nunca ter medido esforços pra me ajudar, estando em São Paulo ou em Cincinnati, e principalmente por ser amiga em todos os sentidos da palavra. Di, sem você eu não teria chegado até aqui.

Às irmãs caçulas Mariane, Bel e Lorena, pela ajuda inestimável na construção desse trabalho, e principalmente por sempre me darem uma razão para sorrir durante o trabalho, mesmo naqueles dias em que todos os experimentos dão errado.

A Simone Bernardino, por ter sido a primeira pessoa a me oferecer amizade em São Paulo e por ter me dado tanto apoio num dos momentos mais difíceis da minha vida. Si, jamais vou esquecer! Obrigada por tanto carinho.

A Roseane Costa, por tanto carinho e por ter me suportado nos bons e maus dias. Obrigada pela amizade tão carinhosa, Rose! 
Aos demais companheiros de laboratório, Fábio, Alda e Priscilia, pela ajuda preciosa nos mais diversos momentos, e aos companheiros que já não estão mais conosco, mas cuja ajuda foi da mesma forma inestimável, Danielle Paixão, Maria Amélia, Benício, Raphael, Vítor e Carol.

Às secretárias Jotelma, Valéria e Eny, por pacientemente nos socorrerem pelos caminhos da burocracia.

Aos queridos funcionários da portaria, principalmente Milton, Otacílio e Nélson, segurança, limpeza, áudio-visual e biblioteca por estarem sempre prontos a fazer a parte de vocês com tanta dedicação o que facilita imensamente a conclusão da nossa parte. Obrigada, pessoal!

À FAPESP e ao CNPq, pelo suporte financeiro para a realização deste trabalho. 


\section{RESUMO}

FALCÃO, D.A. Deficiências concomitantes da proteína reguladora Fator $\mathbf{H}$ e do componente C9 do complemento. Dissertação (Doutorado em Imunologia) - Instituto de Ciências Biomédicas, Universidade de São Paulo, 2007.

A deficiência completa de FH é um fenômeno raro, com apenas 22 casos descritos na literatura até o momento, e com poucos esclarecimentos acerca dos aspectos moleculares dessa deficiência. O componente C9 é a última proteína a ser incorporada no complexo de ataque à membrana e sua deficiência, apesar de rara em caucasianos é de alta prevalência entre os japoneses. Nosso paciente, um menino de aproximadamente 4 anos, é brasileiro, mas de família descendente de japoneses e com histórico de consagüinidade. Ele apresenta deficiência das duas proteínas, FH e C9, cujos aspectos clínicos e moleculares são descritos e avaliados neste trabalho.

O paciente apresentou episódios recorrentes e graves de pneumonia. Ensaios de imunodifusão radial e ELISA determinaram níveis reduzidos de FH (faixa normal em crianças de em crianças de 1 a 5 anos: 233 a $1319 \mu \mathrm{g} / \mathrm{ml}$ e em adultos: 241 a $758 \mu \mathrm{g} / \mathrm{ml}$ [Ferreira de Paula et al, 2003]) no soro do paciente $(16,8 \mu \mathrm{g} / \mathrm{ml})$ e no de seus familiares. O componente C3 e o Fator B (FB) também estavam reduzidos no soro do paciente (abaixo do limite de detecção do método e $<57 \mu \mathrm{g} / \mathrm{ml}$, respectivamente) e no de sua mãe $(382,6 \mu \mathrm{g} / \mathrm{ml}$ e 62,4 $\mu \mathrm{g} / \mathrm{ml}$, respectivamente), mas normal nos soros do pai e da irmã. Através do método de Western Blot observamos a completa ausência das proteínas de 150 kDa (FH) e de 42 kDa (FHL-1) no soro do paciente, mas a presença de outras proteínas antigenicamente relacionadas a ele, como, FHR-1 $\beta$ (42 kDa) e FHR-1 $\alpha$ (37 kDa). Nos soros de seus pais todas as proteínas estavam presentes. Apesar de termos detectado concentrações normais dos componentes C5-C8, participantes da via terminal, no soro do paciente, a presença de C9 não pôde ser detectada. Assim, usando o Western Blot pudemos observar a presença do componente C9 $(70 \mathrm{kDa})$ no soro do paciente, mas em intensidade muito reduzida quando 
comparada à encontrada no soro controle. Esta observação reduz a possibilidade de um stop códon prematuro como causa da deficiência de C9 neste paciente. Utilizando o método de RT-PCR nós amplificamos diversos fragmentos do cDNA de FH do paciente e, em seguida, os seqüenciamos. Foi detectada a substituição homozigota de um nucleotídeo na posição 453 (G453A), levando à substituição de uma Arg por uma His na posição 127. Esta mesma mutação foi encontrada na mãe do paciente e também na forma homozigota e deve alterar a estrutura secundária da proteína e/ou afetar seu perfil de secreção. Através da técnica de PCR amplificamos todos os éxons do DNA genômico de C9 do paciente e os seqüenciamos. Foi observado que o paciente não tem a mutação localizada na posição da Arg95 no éxon 4 e que é considerada como a principal causa da deficiência de C9 entre os japoneses. Assim, o paciente tem ausência completa da proteína reguladora $\mathrm{FH}$, mas dispõe de outros membros da família de proteínas do FH. Ele apresenta uma alteração molecular que leva à codificação de uma His na posição 127 ao invés da Arg na proteína, causando transtornos à secreção desta proteína pelas células do paciente, uma vez que detectamos a produção desta proteína nos fibroblastos do paciente por microscopia confocal. O C9 não está completamente ausente, mas presente em concentrações muito reduzidas em comparação com o controle normal. Entretanto, o paciente não tem a mutação comumente associada com a deficiência desta proteína entre os japoneses e nenhuma mutação que pudesse explicar a deficiência desta proteína pôde ser encontrada. Este paciente é o primeiro caso de deficiência de FH descrita em uma família brasileira e, até onde temos conhecimento, o único caso no mundo de deficiência concomitante entre a proteína reguladora FH e o componente C9.

PALAVRAS-CHAVES: Complemento. Imunologia. Fator H. C9. Imunodeficiências. 


\begin{abstract}
FALCÃO, D.A. Concomitant deficiencies of complement Factor $\mathbf{H}$ regulatory protein and C9 component. Doctor thesis (Immunology) - Instituto de Ciências Biomédicas, Universidade de São Paulo, 2007.
\end{abstract}

Complete Factor (F) H deficiency e rare, with only 22 cases described so far and little is known concerning its molecular basis. C9 component is the last one to be incorporated into the Membrane Attack Complex (MAC) and its deficiency, while rare in Caucasians is quite prevalent in Japanese population. The proband, a 9 years old boy, is Brazilian with a Japanese descent and history of consanguinity. He presents both, FH and C9 deficiency (C9D), and here we describe its clinical aspects and molecular basis.

The patient presented with severe and recurrent pneumonia. Radial Immunodiffusion and ELISA assays showed low levels of FH (1 to 5 years old normal range: 233 a $1319 \mu \mathrm{g} / \mathrm{ml}$ and adults: 241 a $758 \mu \mathrm{g} / \mathrm{ml}$ [Ferreira de Paula et al, 2003]) in patient's (16,8 $\mu \mathrm{g} / \mathrm{ml})$ and his family sera. C3 and Factor B (FB) were also present at low levels in patient's (undetectable) and his mother sera $(382,6 \mu \mathrm{g} / \mathrm{ml}$ e $62,4 \mu \mathrm{g} / \mathrm{ml}$, respectively), while normal in his father and sister sera. Western Blot assays showed the complete absence of the $150 \mathrm{kDa}(\mathrm{FH})$ and the 42 kDa (FHL-1) in patient's serum, while others antigenicaly FH related proteins, such as FHR$1 \beta(42 \mathrm{kDa})$ e FHR-1 $\alpha(37 \mathrm{kDa})$ were present. His parent's sera presented all the proteins of FH protein family evaluated. While C5-C8 components, terminal pathway components, were detected at normal levels at patient's serum, the C9 could not bet detected. Western Blot assays showed a very $~ 70 \mathrm{KDa}$ band (C9 size) in patient's serum, when compared with the normal control. This result makes unlikely a stop codon as the probable cause of the patient's C9D. Using RT-PCR assays we amplified different patient's FH cDNA fragments and sequenced them. We detected a homozygous mutation at 453 position (G453A), encoding and His ${ }^{127}$ Arg. The same mutation is also homozygous in the mother and may alter the protein tertiary structure and/or affect is secretion profile. Using PCR assays we amplified all 11 
exons of patients C9 genomic DNA and sequenced them. We detected that the patient lacks The $\mathrm{Arg}^{95}$, at exon 4, mutation, the main cause of the C9D in the Japanese population. In conclusions, the patient has a complete absence of the FH and FHL-1 regulatory proteins, but does have others members of $\mathrm{FH}$ protein family. He carries a His ${ }^{127}$ Arg mutation that may difficult FH secretion, as we could detect FH production in patient's fibroblast by confocal microscopy. C9 is not completely absent, but present in very low concentrations compared with normal control. The patients lacks the $\operatorname{Arg}^{95}$ mutation and couldn't detect another mutation that could be related to his C9D. This is the first case of complete FH and C9 deficiency in a Brazilian patient and to our knowledge the first case in the literature of a FH and C9 concomitant deficiency.

Key words: Complement. Immunology. Factor H. C9. Immunodefficiencies. 


\section{LISTA DE ABREVIATURAS}

aa: aminoácido.

AP50: ensaio hemolítico da via alternativa que compara valores obtidos para 50\% de lise no soro.

BCIP: 5-bromo-4-cloro-3-indoil fosfato.

C4BP: do inglês $C 4 b$ binding protein.

cDNA: DNA complementar.

C: Complemento.

C1-In: Inibidor de C1

C3FNe: fator nefrítico de C3.

C4FNe: fator nefrítico de C4.

CH50: ensaio hemolítico da via clássica que compara valores obtidos para $50 \%$ de lise no soro.

CFD: do inglês complement fixation buffer.

CPN: carboxipeptidase N.

CR1: do inglês complement receptor 1 .

CR3: do inglês complement receptor 3.

CRP: Proteína-C reativa.

DAF: do inglês decay -accelerating factor.

DMEM: do inglês Dubbelco's Modified Eagle's Médium.

DMRI: degeneração da mácula associada à idade.

DNA: ácido desoxirribonucléico.

dNTP: desoxirribonucleotídeo trifosfato.

EDGF: do inglês Epidermal Grouwth Factor.

EGTA: ácido etileno glicol tetracético.

EtOH: etanol.

FB: Fator B.

FD: Fator D.

FH: Fator H.

FHL-1: do inglês Factor H-like 1 protein.

FHR-1/2/3/4/5: do inglês Factor $H$ related proteins.

FI: Fator I.

GAPDH: gliceraldeído-3-fosfato desidrogenase.

GVB: do inglês gelatin veronal buffer.

HRF: do inglês homologous restriction factor.

HPN: hemoglobinúria paroxística noturna.

INF: interferon.

LPS: lipopolissacarídeo.

MAC: complexo de ataque à membrana.

Map19: do inglês mannose associated plasma protein of $19 \mathrm{kDa}$.

MASP - 1/2/3: do inglês $M B L$-associated serino protease.

MBL: lectina ligadora de manose.

MCP: do inglês membrane cofactor protein.

MPGN II: glomerulonefrite membranoproliferativa tipo II.

NaOAc: acetato de sódio.

NBT: tetrazólico nitroazul.

P: properdina.

PBS: do inglês phosphate buffer saline. 
PCR: do inglês polymerase chain reaction.

RNA: ácido ribonucléico.

RT-PCR: do inglês reverse transcriptase - polymerase chain reaction.

SBF: soro bovino fetal.

SCR: do inglês short consensus repeat.

SDS: dodecil sulfato de sódio.

SFLT: seqüência de aminoácidos terminais She, Phe, Thr e Leu.

SHU: síndrome hemolítico-urêmica.

TBE: do inglês Tris-buffer-EDTA.

TE: do inglês Tris-EDTA. 


\section{LISTA DE FIGURAS:}

Figura 1: Cascatas de ativação das vias clássica e das lectinas do complemento.......................3

Figura 2: Cascata de ativação da via alternativa do complemento........................................

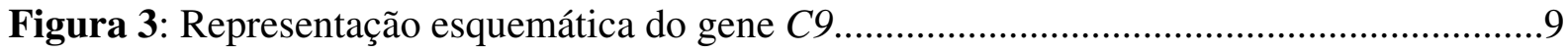

Figura 4: Representação esquemática da estrutura do C9 e do poli (C9)..............................10

Figura 5: Representação esquemática da estrutura do FH..................................................16

Figura 6: Representação esquemática do gene $F H$. O gene compreende 94 kb e 23 éxons

Figura 7: Representação esquemática da inibição da via alternativa pelo FH........................17

Figura 8: Representação esquemática da influência de superfícies ativadoras e não ativadoras

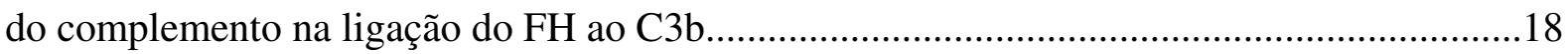

Figura 9: Modelo proposto para a ligação do FH a células endoteliais.................................19

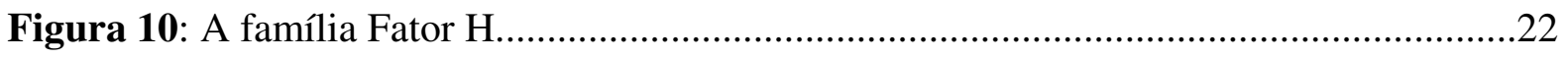

Figura 11: Sequiência de eventos que levam à lesão tecidual em pacientes com SHU e mutações no FH.

Figura 12: Mutações descritas no gene $F H$ e sua equivalente distribuição pelos SCRs do Fator $\mathrm{H}$. .45

Figura 13: Representação esquemática dos fragmentos do cDNA de FH (3926 pb) amplificados e posteriormente seqüenciadas .70

Figura 14: Análise do perfil do FH, e das proteínas antigenicamente relacionadas a ele, presentes no soro do paciente e de sua família através de Western Blotting usando anticorpo policlonal de cabra anti-FH humano

Figura 15: Análise do perfil do FH e do FHL-1 presentes no soro do paciente e de sua família através de Western Blotting utilizando anticorpo policlonal de coelho anti-SCR(1-4) humano. 
Figura 16: Avaliação da presença de C9 no soro do paciente e de seus familiares em comparação com o controle normal através da imunodifusão dupla......

Figura 17: Análise do perfil do C9 presente no soro do paciente e de sua família através de Western Blotting utilizando anticorpo policlonal de cabra anti-C9 humano como primário. 92

Figura 18: Análise de fragmentos do cDNA de FH do paciente e de um controle normal amplificados por RT-PCR

Figura 19: Alteração molecular encontrada no cDNA de FH do paciente de forma homozigota..... 95

Figura 20: Alterações moleculares encontradas no cDNA de FH do paciente. .96

Figura 21: Alteração molecular encontrada nos dois alelos do DNA genômico de FH da mãe do paciente.

Figura 22: Alteração molecular encontrada em um dos alelos do DNA genômico de FH do pai do paciente. .98

Figura 23: Análise de fragmentos éxon-específicos, amplificados por PCR, do DNA de C9 do paciente em comparação com um controle normal. .99

Figura 24: Polimorfismos encontrados no DNA genômico do paciente na região do gene C9. 101

Figura 25: Presença de FH no citoplasma de fibroblastos observados por microscopia confocal 103 


\section{LISTA DE TABELAS:}

Tabela 1: Casos de Deficiência Hereditária de FH...............................................................36

Tabela 2: Valores dos parâmetros de hemograma avaliados no paciente 56

Tabela 3: Concentrações das classes de imunoglobulinas encontradas no soro do paciente .57

Tabela 4: Concentrações das subclasses de IgG encontradas no soro do paciente .57

Tabela 5: Avaliação da presença de anticorpos da classe IgM e IgG contra os agentes etiológicos da rubéola, sarampo e AIDS .58

Tabela 6: Avaliação das subpopulações de linfócitos encontradas no soro do paciente 58

Tabela 7: Avaliação da resposta proliferativa dos linfócitos do paciente a determinados mitógenos .59

Tabela 8: Avaliação da produção de anticorpos anti-pneumococo pelo paciente após administração da vacina pneumo.

Tabela 9: Porcentagem das Atividades Hemolíticas Dependentes das Vias Clássica e Alternativa nos Soros do Paciente e de Sua Família.

Tabela 10: Concentração de $\mathrm{C} 3, \mathrm{C} 4, \mathrm{FB}, \mathrm{FI}$ e properdina no soro do paciente e de su família 79

Tabela 11: Concentração de FH nos Soros do Paciente e de Sua Família 82

Tabela 12: Proteínas da família FH encontradas nos soros do paciente e de seus familiares

Tabela 13: Concentração de C9 nos Soros do Paciente e de Sua Família...... .90 


\section{LISTA DE QUADROS:}

Quadro 1: Oligonucleotídeos utilizados em RT-PCR, PCR e seqüenciamento do cDNA de FH.. .69

Quadro 2: Oligonucleotídeos utilizados em PCR e seqüenciamento das regiões de C9 a partir de DNA genômico. .72

Quadro 3: Alinhamento do FH entre espécies. 113 


\section{SUMÁRIO}

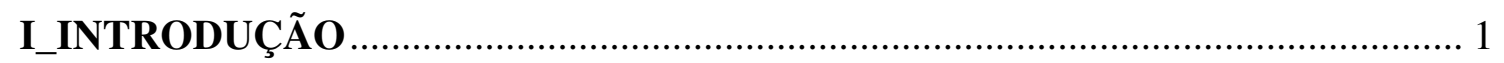

1.1 Ativação do Sistema Complemento ……......................................................... 2

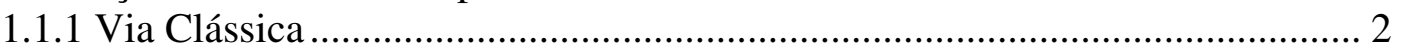

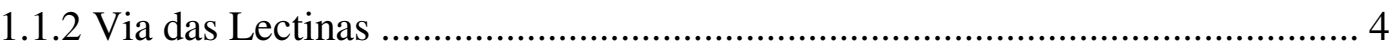

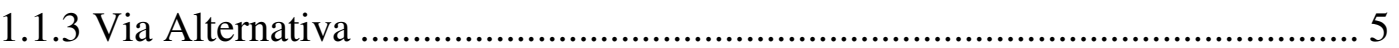

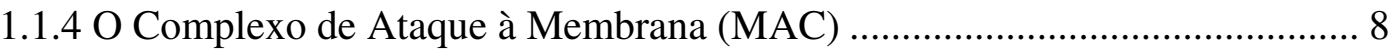

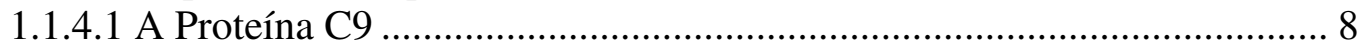

1.2 Regulação da Ativação do Sistema Complemento.Erro! Indicador não definido.

1.2.1 Proteínas Reguladoras Solúveis ......................Erro! Indicador não definido.

A Proteína Reguladora Fator H (FH) ...................Erro! Indicador não definido.

1.2.7.1 Domínios funcionais do FH...................Erro! Indicador não definido.

A Família de Proteínas do FH ..........................Erro! Indicador não definido.

O FHL-1 ....................................................

FHR-1 e FHR-2 .........................................Erro! Indicador não definido.

FHR-3 e FHR-4 .........................................Erro! Indicador não definido.

FHR-5 .......................................................Erro! Indicador não definido.

1.2.2 Proteínas Reguladoras Ligadas à Membrana CelularErro! Indicador não definido.

1.3 Deficiências do Sistema Complemento ............................................................... 27

1.3.1 Deficiência de Componentes da Via Clássica .............................................. 27

1.3.2 Deficiência dos Componentes da Via AlternativaErro! Indicador não definido.

1.3.3 Deficiência dos Componentes da Via TerminalErro! Indicador não definido.

Deficiência de C9

Erro! Indicador não definido.

1.3.4 Deficiência de Proteínas Reguladoras da Ativação do Complemento ......Erro!

Indicador não definido.

1.3.4.1 Deficiência de Proteínas Reguladoras SolúveisErro! Indicador não definido. DEFICIÊNCIA DE FH. Erro! Indicador não definido.

Doenças Relacionadas à Deficiência de FH.Erro! Indicador não definido.

1.3.4.2 Deficiência de Proteínas Reguladoras Associadas à Membrana CelularErro! Indicador não definido.

II_HIPÓTESE E OBJETIVOS DO TRABALHO .......Erro! Indicador não definido.

2.1 Hipótese do Trabalho

2.2 Objetivos Gerais

2.3 Objetivos Específicos

III_DELINEAMENTO EXPERIMENTAL

IV_MATERIAIS E MÉTODOS

4.1 Paciente

4.2 Atividade Hemolítica mediada pela Via Clássica

4.3 Atividade Hemolítica mediada pela Via Alternativa

4.4 Imunodifusão Radial

4.5 Imunodifusão dupla

4.6 Enzyme-linked Immunosorbent Assay (ELISA).

4.6.1 ELISA para FH

4.6.2 ELISA para C9

4.7 Western Blot.

4.8 Cultura de Fibroblastos da Pele

4.9 Extração de RNA Total

4.10 Quantificação do RNA
Erro! Indicador não definido. Erro! Indicador não definido. Erro! Indicador não definido. Erro! Indicador não definido. Erro! Indicador não definido. Erro! Indicador não definido. 
4.11 "Reverse transcriptase-polymerase chain reaction" (RT-PCR) para Amplificação do cDNA de FH....

4.12 PCR para Amplificação dos Éxons de C9 …….............................................. 71

4.13 Purificação do DNA a Partir do Gel de Agarose.................................................. 73

4.14 Extração de DNA Genômico Utilizando DNAzol .............................................. 73

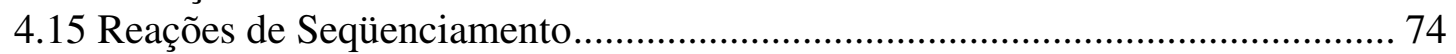

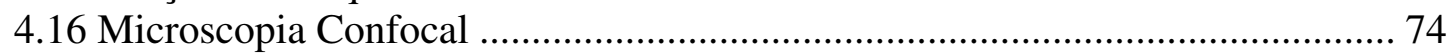

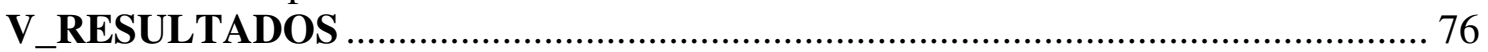

5.1 Determinação das Atividades Hemolíticas das Vias Clássica e Alternativa no Soro do Paciente e de Seus Familiares. 76

5.2 Determinação da Concentração das Proteínas do Complemento no Soro do Paciente e de sua Família. 78

5.2.1 Determinação da Concentração de C3, C4, FB, FI e properdina no Soro do Paciente e de sua Família Utilizando o método de Imunodifusão Dupla 79

5.2.2 Determinação da Concentração de FH no Soro do Paciente e de sua Família Utilizando o método ELISA. 81

5.3 Avaliação do Perfil das Proteínas da Família FH no Soro do Paciente e de Seus Familiares Utilizando o Western Blot.

5.4 Imunodifusão Dupla Para Detecção das Proteínas da Via Terminal: C6, C6, C7, C8 e C9. 88

5.5 Determinação da Concentração de C9 no Soro do Paciente e de Seus Familiares Utilizando o Método ELISA.

5.6 Avaliação do Perfil do C9 no Soro do Paciente e de Sua Família Pelo Western Blot.

5.7 Amplificação do cDNA do FH do Paciente

5.8 Seqüenciamento do cDNA de FH do Paciente 93

5.9 Amplificação Éxon-específica do DNA Genômico de C9 do Paciente 94

5.10 Seqüenciamento dos Éxons e Pequenas Porções dos Íntrons do DNA genômico para C9 do Paciente. 99

5.11 Avaliação do FH Intracelular em Fibroblastos do Paciente por Microscopia Confocal. 


\section{I_INTRODUÇÃ̃O}

A história do complemento inicia-se em 1888, quando Nutall observou que o soro de animais normais exibia uma toxicidade espontânea contra determinados microorganismos (SILVERSTEIN, 1989). Em 1899, Buchner identificou, em soros frescos e livres de células, um componente termolábil capaz de provocar bacteriólise, e o chamou de "alexina" (palavra grega que significa "sem nome”) (MORLEY \& WALPORT, 2000). Ainda em 1899, Ehrlich deu a esse componente o nome de "complemento" (SILVERSTEIN, 1989). Entretanto, o primeiro trabalho descrevendo a fixação do complemento e seu papel quantitativo na lise de células foi elaborado por Bordet e Gengou em 1909, rendendo a Bordet o crédito pelo descobrimento do sistema complemento (MORLEY \& WALPORT, 2000; SILVERSTEIN, 1989).

Sabe-se, hoje, que o termo complemento refere-se a um grupo complexo de aproximadamente 30 proteínas (plasmáticas ou ligadas a membranas celulares), que, juntas, desempenham um papel essencial no reconhecimento e eliminação de microorganismos, remoção de imunocomplexos e células apoptóticas, bem como na inflamação (KÖHL, 2006). Por ser encontrado principalmente no soro e em outros fluidos corporais, o complemento foi caracterizado como integrante da imunidade humoral da resposta imune (MAYER, 1973).

O complemento é um dos principais elementos da imunidade inata, sendo capaz de participar da primeira barreira defensiva contra microorganismos invasores, através da ativação de sua cascata enzimática, com conseqüente opsonização e lise dos microorganismos (KÖHL, 2006). 


\subsection{Ativação do Sistema Complemento}

\subsubsection{Via Clássica}

A formação do complexo antígeno-anticorpo é o primeiro passo para início da cascata de ativação da via clássica do complemento (COLTEN, 1992). A união do antígeno ao anticorpo acaba por expor sítios ativos na porção Fc do anticorpo, das classes $\operatorname{IgM}$ ou $\operatorname{IgG}$ onde se liga o complexo $\mathrm{C} 1$, formado por uma molécula de $\mathrm{C} 1 \mathrm{q}$ e duas de $\mathrm{C} 1 \mathrm{~s}$ e de $\mathrm{C} 1 \mathrm{r}$, unidas por pontes não-covalentes dependentes de $\mathrm{Ca}^{2+}$ (Figura 1). Ao ligar-se ao anticorpo o C1q sofre mudanças estruturais que o tornam ativo e capaz de clivar C1r que, também uma vez ativo, cliva o $\mathrm{C} 1 \mathrm{~s}$.

Por meio de uma reação dependente de $\mathrm{Mg}^{2+}$, o C1s cliva o componente $\mathrm{C} 4$, em C4a e $\mathrm{C} 4 \mathrm{~b}$, e o componente $\mathrm{C} 2$, em $\mathrm{C} 2 \mathrm{a}$ e $\mathrm{C} 2 \mathrm{~b}$. Uma vez complexados, os fragmentos $\mathrm{C} 4 \mathrm{a}$ e $\mathrm{C} 2 \mathrm{~b}$ formam uma protease $(\mathrm{C} 4 \mathrm{~b} 2 \mathrm{a})$, a C3 convertase da via clássica. Esta convertase cliva o componente $\mathrm{C} 3$ em C3a e C3b. Unindo-se ao complexo $\mathrm{C} 4 \mathrm{aC} 2 \mathrm{~b}$, o $\mathrm{C} 3 \mathrm{~b}$ participa da formação da segunda enzima da via clássica, a C5 convertase (C4b2aC3b). Esta enzima tem o poder de clivar o C5 em C5a e C5b. Com a formação do fragmento C5b tem início a via terminal, para a qual convergem todas as vias de ativação do C (JAMES, 1982).

Costuma-se associar a ativação da via clássica do complemento como um fenômeno dependente da presença de anticorpos. Entretanto, vários estudos já mostraram que DNA, proteína C-reativa, membranas mitocondriais e vírus são capazes de ativar diretamente a via clássica, independentemente da presença de anticorpos (COLTEN, 1992), uma vez ligadas diretamente ao C1q. 


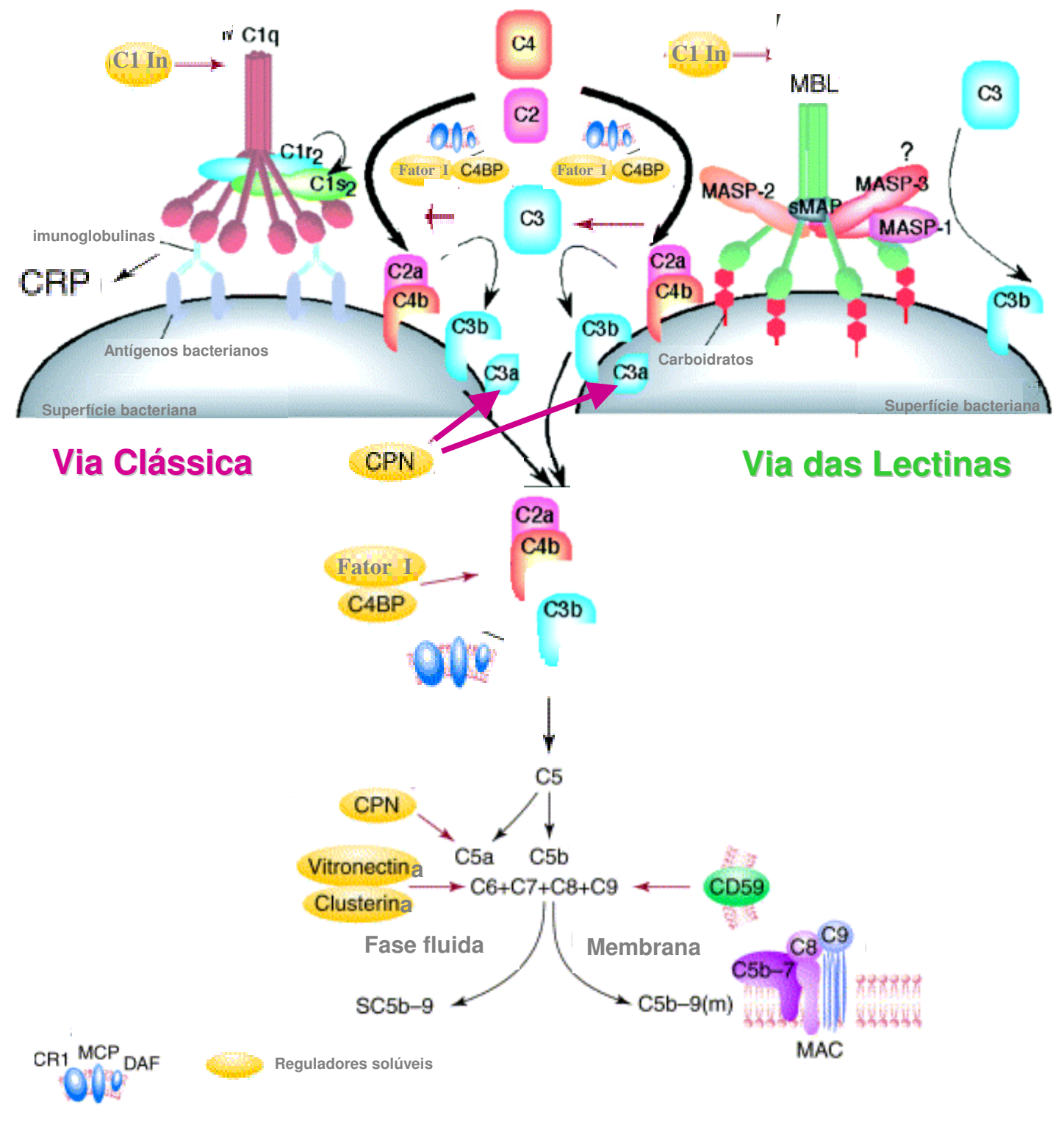

Figura 1: Cascatas de ativação das vias clássica e das lectinas do complemento. C1-In: inibidor de C1, CRP: proteína C reativa, C4BP: proteína ligante de C4b, CPN: carboxipeptidase-N, CR1: receptor de Complemento tipo 1, DAF: fator de aceleração do decaimento, MAC: complexo de ataque à membrana, MBL: lectina ligante de manose, MCP: proteína co-fator de membrana. Modificado a partir de FUJITA et al, 2004 e MOLLNES et al, 2002. 


\subsubsection{Via das Lectinas}

Em 1975, observou-se que proteínas encontradas nas células do fígado de mamíferos apresentavam afinidade pela manose, semelhante à exibida pelas lectinas. Três anos depois elas foram purificadas de extratos hepáticos de coelho e no soro de humanos, bovinos, ratos e camundongos. Estava identificada, então, a MBL (mannose-binding lectin) (TURNER, 1996).

A MBL humana é uma lectina do tipo $\mathrm{C}$ que se liga a $\mathrm{N}$-acetilglicosamina, $\mathrm{D}$-manose, L-fucose, glicose, e galactose (TURNER, 1996) encontradas, por exemplo, na parede de bactérias Gram-negativas, na presença de íons cálcio (MATSUSHITA \& FUJITA, 1992). A MBL é muito semelhante estrutural e funcionalmente à subunidade $\mathrm{C} 1 \mathrm{q}$ do complexo $\mathrm{C} 1$ encontrado na via clássica (ROOS et al, 2001).

Em 1987, Ikeda et al propuseram que a MBL seria capaz de ativar o complemento por meio da via clássica (IKEDA et al, 1987). Três anos depois, dois estudos afirmaram que a ativação ocorreria por meio da interação da MBL com o complexo $\mathrm{C} 1 \mathrm{r}_{2}-\mathrm{C} 1 \mathrm{~s}_{2}$ após ligação da primeira à manose encontrada na superfície dos microorganismos (LU et al, 1990; OHTA et al, 1990).

Sabe-se hoje, entretanto, que a MBL encontra-se associada a serino-proteases distintas de $\mathrm{C}_{1} \mathrm{r}_{2}$ e $\mathrm{C} 1 \mathrm{~s}_{2}$. Essas enzimas, conhecidas como MASPs (MBL-associated serine proteases) são as responsáveis pela propriedade de ativação do complemento exibidas pela MBL. Ao se ligarem a açúcares presentes na membrana de microorganismos, a MBL sofre uma modificação estrutural capaz de ativar as MASP-1 e MASP-2 que, então, clivam C3 (MASP1), além de C4 e C2 (MASP-2) (Figura 1) (ROOS et al, 2001; FUJITA, 2002). Stover e seus colaboradores (1999) definiram a estrutura primária de uma outra proteína encontrada também acoplada à MBL, a MAp19, mas sem função enzimática conhecida, enquanto Dahl et al (2001) registraram a existência da MASP-3, uma inibidora da clivagem de C4 e C2 pela MASP-2. 
Ainda em 2001, Roos et al revelaram a possibilidade de ativação da via das lectinas através da ligação da MBL com IgA. Essa ligação ocorreria na presença de $\mathrm{Ca}^{2+}$, através do domínio de reconhecimento de carboidratos (CRD) da MBL de forma diretamente proporcional à concentração de MBL e IgA. Uma vez ligada à IgA, a MBL foi capaz provocar a deposição de C3b e C4b pela degradação de C3 e C4 encontrados no soro humano normal (ROOS et al, 2001).

\subsubsection{Via Alternativa}

Descoberta em 1954 por Louis Pillemer e Ecker, que demonstraram a ligação e ativação do C3 nas paredes celulares das leveduras (SILVERSTEIN, 1989), a via alternativa só foi oficialmente aceita pela comunidade científica após o trabalho de Gewurz et al em 1968, que mostraram o consumo do componente C3 na presença de lipopolissacarídeo (LPS) e sem a participação de C1, C2 ou C4 (JAMES, 1982).

Esta via difere da via clássica primeiramente pela possibilidade de ativação na ausência de moléculas de anticorpo, fornecendo uma linha de defesa inata imediata, dispensando imunização prévia (PANGBURN \& MÜLLER-EBERHARD, 1984). Associado a isso, existe o fato de que a via alternativa é ativada constantemente em condições fisiológicas, mesmo em níveis baixos (JÓZSI et al, 2004). Para tanto, esta via requer a participação de C3 e de pelo menos três outras proteínas exclusivas desta via: o Fator B (FB), o Fator D (FD) e a properdina (MORGAN \& HARRIS, 1999).

A ativação da cascata enzimática da via alternativa é iniciada pela hidrólise espontânea da ligação tiól-éster localizada intramolecularmente na cadeia $\alpha$ da molécula nativa de C3, levando-a a um rearranjo conformacional responsável pela formação de uma molécula estrutural e funcionalmente semelhante ao fragmento $\mathrm{C} 3 \mathrm{~b}$, o $\mathrm{C} 3\left(\mathrm{H}_{2} \mathrm{O}\right) . \mathrm{C} 3\left(\mathrm{H}_{2} \mathrm{O}\right)$ tem a capacidade de ligar-se ao FB, à Properdina, ao Fator H e C5. Vale ressaltar que, apesar da 
iniciação desta via ser espontânea e ocorrer constantemente em condições fisiológicas, a formação do $\mathrm{C} 3\left(\mathrm{H}_{2} \mathrm{O}\right)$ ocorre em percentuais muito baixos $(0,2-0,4 \% / h)$, além de ser passível de regulação pelas proteínas FH e Fator I (FI) (PANGBURN \& MÜLLER-EBERHARD, 1983a).

Uma vez formado, e na presença de $\mathrm{Mg}^{2+}$, o $\mathrm{C} 3\left(\mathrm{H}_{2} \mathrm{O}\right)$ liga-se ao FB que é, então, clivado pela protease FD, produzindo os fragmentos $\mathrm{Ba}$ e $\mathrm{Bb}$ (Figura 2). O fragmento $\mathrm{Bb}$ permanece ligado ao $\mathrm{C} 3\left(\mathrm{H}_{2} \mathrm{O}\right)$ e forma-se, então a primeira $\mathrm{C} 3$ convertase da via alternativa, C3( $\left.\mathrm{H}_{2} \mathrm{O}\right) \mathrm{Bb}$ (PANGBURN \& MÜLLER-EBERHARD, 1984).

Uma vez formados os novos fragmentos de C3, eles se ligam às superfícies aceptoras, assim como visto com o $\mathrm{C} 3\left(\mathrm{H}_{2} \mathrm{O}\right)$, e podem se ligar ao $\mathrm{FB}$ e gerar o complexo $\mathrm{C} 3 \mathrm{bBb}$, após a clivagem do FB pelo FD. Desta maneira, forma-se a segunda C3 convertase da via alternativa, C3bBb. Fica então caracterizada a alça de amplificação da via alternativa (Figura 2), onde cada molécula de $\mathrm{C} 3\left(\mathrm{H}_{2} \mathrm{O}\right)$ gerada espontaneamente pode formar uma $\mathrm{C} 3$ convertase e gerar novas moléculas de C3b que, por sua vez, formarão outras C3 convertases (PANGBURN, 1983b).

A segunda $\mathrm{C} 3$ convertase da via alternativa, $\mathrm{C} 3 \mathrm{bBb}$, clivará novas moléculas nativas de C3 e novas unidades de C3b serão formadas. Quando permanecer ligado à C3 convertase, o C3b formará então a C5 convertase da via alternativa: C3bBbC3b. Formada a C5 convertase, moléculas nativas de C5 serão clivadas, e os fragmentos C5a e C5b serão gerados (PANGBURN \& MÜLLER-EBERHARD, 1983a). 



\subsubsection{O Complexo de Ataque à Membrana (MAC)}

Apesar de serem iniciados por mecanismos diferentes, todos os mecanismos de ativação levam à formação de uma via comum (terminal) que resulta na deposição de um complexo denominado complexo de ataque à membrana (MAC, do inglês Membrane Attack Complex). Este complexo normalmente deposita-se principalmente sobre as superfícies de microorganismos, ou sobre as membranas de células infectadas por alguns tipos de vírus e de certas linhagens de células tumorais (PANGBURN, 1984).

A formação deste complexo é iniciada pela clivagem do C5, seja pela via clássica, alternativa ou das lectinas, e envolve a deposição de outros componentes, (C6, C7, C8 e C9). A ligação do C8 ao complexo já depositado C5b67 permite a formação de pequenos poros nas células-alvo, tornando-as vulneráveis à lise. A ligação da primeira molécula de C9 causa modificações conformacionais que possibilitam a associação de outras unidades do mesmo componente, permitindo o aumento do tamanho do poro na membrana do microorganismo até serem adicionadas até 18 moléculas de C9 (MORGAN \& HARRIS, 1999). A principal consequiência da formação do MAC é a lise osmótica de microorganismos (MÜLLEREBERHARD, 1986; FEARON \& LOCKSLEY, 1996).

\subsubsection{A Proteína C9}

O componente C9 é uma proteína de cadeia simples com 538 aa e peso molecular aproximado de $71 \mathrm{kDa}$. O gene $C 9$ tem aproximadamente $100 \mathrm{~kb}$, é composto por 11 éxons (Figura 3) e está localizado no cromossomo humano 5p13. (WITZEL-SCHLÖMP et al, 1997). 


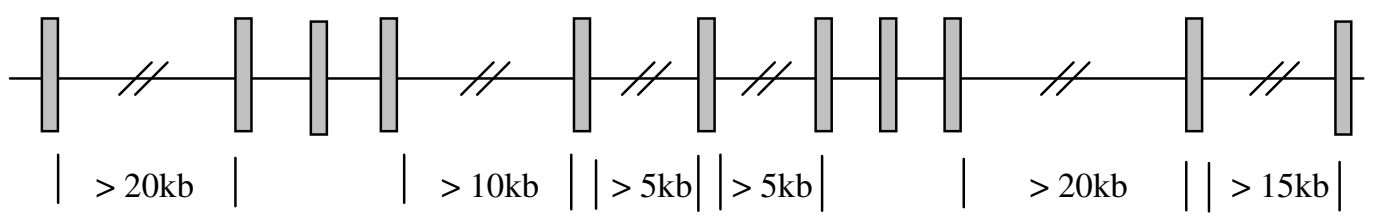

Figura 3: Representação esquemática do gene $C 9$. O gene compreende $100 \mathrm{~kb}$ e contém 11 éxons. O tamanho dos éxons varia de 100 a 350 pb, com exceção do éxon 11 que tem aproximadamente 1000 pb. Os íntrons têm tamanhos variando entre 260 e > 20 kb.

A cadeia polipeptídica de C9 contém vários domínios independentes, com 40 a 60 aa (aa) cada, incluindo 24 cisteínas envolvidas na formação de pontes dissulfídicas intra-cadeia (LENGWEILER et al, 1996). Na porção N-terminal encontram-se os dois primeiros domínios, homólogos à trombospondina e ao receptor tipo A de LDL, respectivamente. A estes dois domínios segue-se uma porção central, com aproximadamente 330 aa, homóloga àquela encontrada na perforina (proteína formadora de poros presente nos linfócitos $\mathrm{TCD}^{+} \mathrm{e}$ células NK) e um domínio na porção C-terminal de estrutura homóloga àquela encontrada no fator de crescimento epidermal (EDGF) (LICHTENHELD et al, 1988; SHINKAI et al, 1988).

C9 é o último componente a tomar parte na cascata de ativação do C. Ele é produzido principalmente pelo fígado, mas também por monócitos, fibroblastos e células da glia (MORLEY \& WALPORT, 2000) e secretado no plasma na forma de uma proteína monomérica solúvel (STANLEY et al, 1985) (Figura 4). 

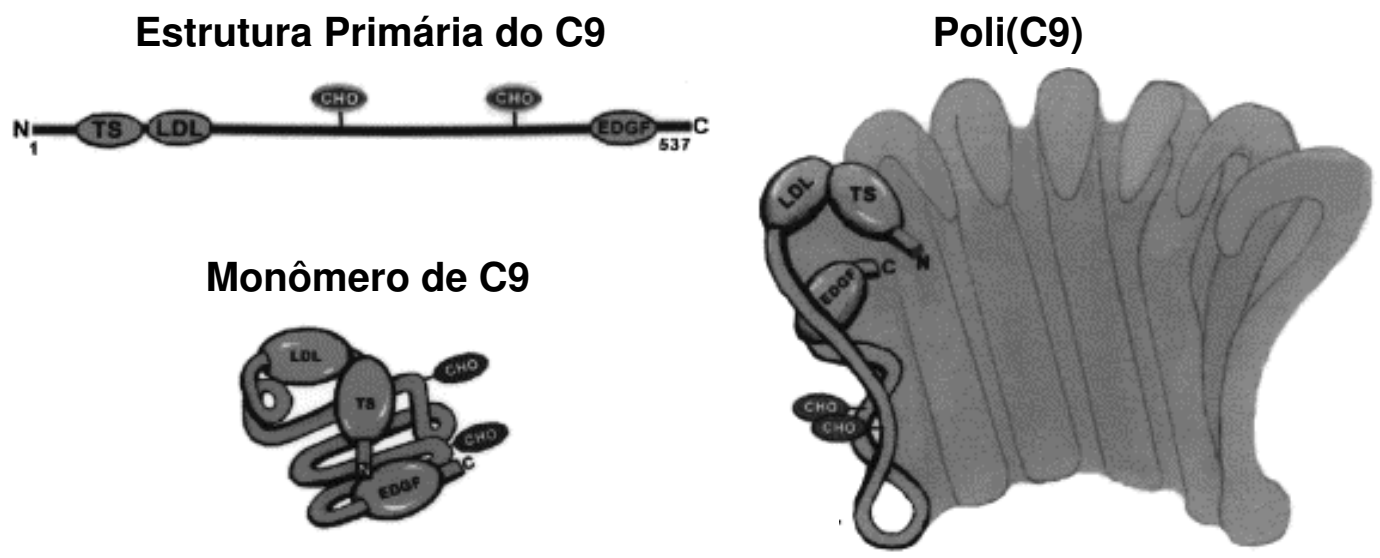

Figura 4: Representação esquemática da estrutura do C9 e do poli (C9). Na estrutura primária identificam-se os dois domínios da porção N-terminal, com homologia à trombospondina (TS) e ao receptor tipo 1 de lipoproteína de baixa densidade $\left(L_{D L}\right)$, uma porção central e um domínio na porção C-terminal, com homologia ao fator de crescimento epidermal (EDGF). As porçõe N-terminal e central estão envolvidas com a formação da borda do poro e com a interação direta com a membrana do microorganismo, respectivamente. Modificado a partir de DISCIPIO \& BERLIN, 1999.

Esta proteína tem a capacidade de polimerizar espontaneamente e criar túbulos circulares com aproximadamente $100 \AA$ de diâmetro [poli C9] (DISCIPIO \&BERLIN, 1999). Em um estudo muito elegante, DiScipio e Berlin (1999) utilizaram fragmentos recombinantes de $\mathrm{C}$, correspondendo às regiões $\mathrm{N}$-terminal, central e C-terminal da proteína, além de anticorpos específicos para cada fragmento, a fim de determinar qual região da proteína seria diretamente implicada na formação do poli (C9). Eles observaram que a porção N-terminal estava implicada na formação da borda superior do cilindro, a região central assumia uma posição transversa da borda superior à borda inferior do cilindro, enquanto a C-terminal retornava às proximidades da borda superior (Figura 4). Eles observaram também que a porção N-terminal da proteína estava diretamente implicada na solubilidade do poli (C9), 
enquanto a região central e a região C-terminal estavam envolvidas na formação do túbulo e na sua capacidade de associação a lipídios (DISCIPIO \&BERLIN, 1999).

Já em 1985, Tschopp et al haviam demonstrado que a presença do complexo C5b-8 acelerava a polimerização circular do C9 (TSCHOPP et al, 1985). E em 1986, Young e seus colaboradores mostraram que a associação do C9 com o complexo C5b-8 em membranas fosfolipídicas criava discretos poros transmembrana que não eram dependentes de íons (YOUNG et al, 1986).

Quando ocorre a formação do C5b67, este se transforma automaticamente em um complexo hidrofóbico e liga-se espontaneamente a membranas celulares. A ligação deste primeiro complexo ao $\mathrm{C} 8$ gera um segundo complexo, o $\mathrm{C} 5 \mathrm{~b}-8$, de formato circular que se insere profundamente na bicamada lípidica, formando um poro pequeno e frágil. Embora o complexo C5b-8 já possa funcionar como um canal iônico, o tamanho e a funcionalidade do MAC estão diretamente relacionados ao número de moléculas de C9 que se associa ao complexo C5b-8. Conseqüentemente, quanto mais moléculas de C9 se ligarem ao C5b-8 (máximo de 18 [BIESECKER et al, 1993]) mais túbulos estruturalmente completos serão formados e um maior número de poros largos, estáveis e funcionais estará disponível (FARKAS et al, 2002; DISCIPIO \& BERLIN, 1999; STANLEY et al, 1985).

\subsection{Regulação da Ativação do Sistema Complemento}

O grau de importância dos mecanismos de regulação do sistema complemento pode claramente ser medido pelo fato de existirem quase tantas proteínas reguladoras, pelo menos 11, quantos componentes participantes das vias do complemento.

A participação de tantas proteínas nesse sistema de controle e, conseqüentemente, a necessidade de sua existência, pode ser justificada de duas maneiras: em primeiro lugar, o 
se hoje, que o C1-In é uma proteína de cadeia simples, de aproximadamente 104 kDa e alto índice de glicosilação (30\%) (BOS et al, 2002), com capacidade de inibir diferentes serinoproteases, como C1r, C1s, MASPs entre outras (CICARDI et al, 2005). No caso de C1r e C1s, o C1-In encontra-se firmemente ligado ao sítio catalítico dessas enzimas, impedido a sua ativação espontânea (ZICCARDI, 1983) ou mesmo promovendo a dissociação delas do complexo C1 e deixando o C1q ligado ao anticorpo (LISZEWSKI et al, 1996). Como já foi dito, este inibidor pode também ligar-se a MASPs, desfavorecendo a ativação tanto da via clássica como da via das lectinas (SIM et al, 1979; MATSUSHITA et al, 2000), mas a importância dessa interação in vivo ainda não está completamente esclarecida (BOS et al, 2002).

A properdina foi descrita pela primeira vez em 1954 por Louis Pillemer ao estudar os mecanismos de inativação do C3 durante incubação com zymosan (MORGAN \& HARRIS, 1999). A properdina é uma glicoproteína solúvel encontrada no plasma na forma de oligômeros (principalmente dímeros, trímeros e tetrâmeros) formados a partir de monômeros com peso molecular aproximado de $53 \mathrm{kDa}$ (TRUEDSSON et al, 1997).

A properdina funciona como um regulador positivo de ativação da via alternativa do complemento, pois ao ligar-se ao complexo $\mathrm{C} 3 \mathrm{bBb}$ estabiliza esta enzima, aumentando o seu tempo de vida (WEILER et al, 1976). Além disso, a properdina inibe a ligação do FI ao C3b, provavelmente por competição (MEDICUS et al, 1976).

A C4BP é uma proteína oligomérica de aproximadamente $500 \mathrm{kDa}$, composta por sete cadeias $\alpha$ e uma $\beta$, organizadas quase exclusivamente em SCRs, oito nas cadeias $\alpha$ e três na $\beta$ (do inglês Short Consensus Repeat). Esta proteína é capaz de controlar as reações mediadas pelo $\mathrm{C} 4 \mathrm{~b}$ e, conseqüentemente, inibir a ativação da via clássica em pelo menos três estágios: como co-fator do FI, prevenindo a formação da C3 convertase da via clássica (C4bC2a) e acelerando o decaimento da atividade dessa enzima (SIM et al, 1993; BLOM et al, 2004). 
sistema complemento é constantemente ativado em níveis baixos sobre as células do organismo e, em segundo lugar, as vias de ativação são cascatas proteolíticas que têm enorme tendência à amplificação, de forma que pequenos estímulos podem levar a respostas imunológicas de grande magnitude e potencialmente danosas ao próprio organismo, e ao consumo excessivo de proteínas participantes das cascatas de ativação, como C3 e FB, o que levaria o indivíduo a apresentar sintomas semelhantes aos exibidos pelos deficientes primários de reguladores da ativação do C (MORGAN \& HARRIS, 1999).

As várias proteínas reguladoras que impedem a ativação contínua do sistema complemento encontram-se agrupadas em duas categorias distintas: a das proteínas reguladoras solúveis no plasma e a das proteínas reguladoras presentes nas membranas celulares. Compondo o grupo das proteínas reguladoras solúveis encontra-se o inibidor de C1,

o FI e FH, a proteína ligante de C4b (C4BP), a vitronectina, a clusterina, a properdina e o inibidor de anafilotoxina. Já no outro grupo, encontra-se a proteína co-fator de membrana (MCP), o fator acelerador do decaimento (DAF), o receptor-1 do complemento (CR1), o fator homólogo de restrição (HRF) e o CD59. Todas essas proteínas desempenham papéis fundamentais nos mecanismos envolvidos na regulação dos procedimentos de ativação do Sistema Complemento, seja pela via clássica, alternativa ou das lectinas (SIM et al, 1993).

\subsubsection{Proteínas Reguladoras Solúveis}

A proteína inibidora de C1 (C1-In) foi descoberta em 1957 por Ratnoff e Lepow ao estudarem preparados frescos do componente $\mathrm{C} 1$ do plasma humano e detectarem a presença de uma esterase com capacidade de inibir esse componente. Entretanto, apenas em 1961 Pensky e seus colaboradores conseguiram isolar parcialmente esta enzima e caracterizá-la como um inibidor de protease diferente dos já descritos (MORGAN \& HARRIS, 1999). Sabe- 
Além do seu papel na regulação do complemento, sabe-se que a C4BP pode, ainda, ligar-se à heparina, à proteína anticoagulante, conhecida por proteína $\mathrm{S}$, e a proteínas presentes na membrana de diversas bactérias (BLOM, 2002).

A vitronectina e a clusterina, ambas proteínas plasmáticas, desempenham papéis similares ao desfavorecer a formação do MAC por competir com o componente 8 (C8) pela ligação com o complexo C5b-67 associado à membrana (PODACK et al, 1977; PODACK, 1984).

O inibidor de anafilatoxinas (C3a e $\mathrm{C} 5 \mathrm{a})$ é uma enzima presente no plasma, a carboxipeptidase $\mathrm{N}(\mathrm{CPN})$, com a capacidade de remover a arginina presente na porção $\mathrm{C}$ terminal das anafilatoxinas, $\mathrm{C} 3 \mathrm{a}, \mathrm{C} 4 \mathrm{a}$ e $\mathrm{C} 5 \mathrm{a}$, o que elimina ou diminui muito o poder inflamatório desses fragmentos (GERARD \& HUGLI, 1981).

O FI é uma glicoproteína formada por duas cadeias (uma leve com 38 kDa e uma pesada com $50 \mathrm{kDa}$ ), com $88 \mathrm{kDa}$. A cadeia pesada é responsável pela interação com os cofatores, enquanto a cadeia leve contém o sítio catalítico serino-proteinase (DISCIPIO, 1992).

O FI regula a ativação de $\mathrm{C} 3$ ao clivar o fragmento $\mathrm{C} 3 \mathrm{~b}$ em iC3b e posteriormente em C3c e C3d, bem como a ativação de C4 ao clivá-lo em iC4b e, posteriormente em C4c e C4d. Entretanto, para desempenhar tal papel, o FI necessita da colaboração de outras proteínas, seus co-fatores: FH, C4BP, MCP e CR1 (MORLEY \& WALPORT, 2000).

\section{A Proteína Reguladora Fator $\mathrm{H}(\mathrm{FH})$}

O FH é uma glicoproteína de cadeia única, pesando 150 kDa, descoberta em 1965 por Nilsson e Müller-Eberhard como uma proteína contaminante de preparações contendo C3 (NILSSON \& MÜLLER-EBERHARD, 1965; SIM \& DISCIPIO, 1982). É composto por uma sequiência de 1213 aa organizados em 20 domínios SCRs (do inglês short consensus repeat) 
cada um com aproximadamente 61 aa (Figura 5) (RIPOCHE et al, 1988). Cada SCR, com exceção do SCR2 que é codificado pelos éxos 3 e 4, é codificado por um éxon dos 23 que compõem o gene $F H$ (Figura 6), localizado no cromossomo 1 humano, próximo a gene outros reguladores da ativação do complemento (RODRIGUEZ DE CÓRDOBA et al, 2004).

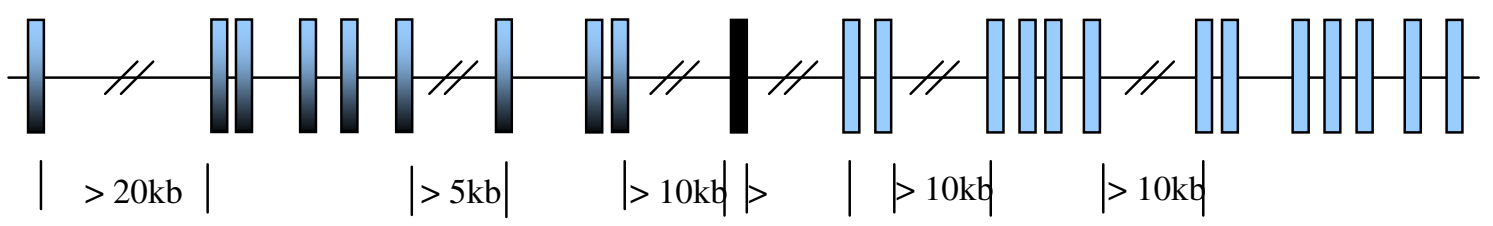

Figura 6: Representação esquemática do gene $F H$. O gene compreende 94 kb e 23 éxons. $\mathrm{O}$ tamanho dos éxons varia de 77 a 360 pb e o dos íntrons de 100 a > 20 kb. Os éxons em azul são responsáveis pela codificação da molécula de FH. O éxon 10, em preto, não contribui para a molécula de FH, mas é utilizado para codificar o FHL-1 (do inglês complemt Factor H Like-1). Os éxons 1 a 9, em azul e preto, são compartilhados pelo FH e FHL-1. 

Alguns anos depois de sua descoberta, entre 1976 e 1989, diferentes estudos atribuíram ao FH seu papel central na regulação da ativação da via alternativa, agindo como co-fator para o FI na clivagem de $\mathrm{C} 3 \mathrm{~b}$ em iC3b, e como inibidor da atividade da $\mathrm{C} 3$ convertase (SILVERSTEIN, 1989).

Para evitar a formação da C3 convertase da via alternativa e a conseqüente amplificação da ativação do C característica desta via, o FH se liga ao sítio não catalítico do $\mathrm{C} 3 \mathrm{~b}$ (ou do $\mathrm{C}_{3} \mathrm{H}_{2} \mathrm{O}$ ), prevenindo a ligação com o $\mathrm{FB}$ ou com o $\mathrm{Bb}$ ou mesmo deslocando-os caso já estejam ligados (Figura 7). Uma vez ligado ao C3b, o FH pode, ainda, atuar como cofator para o FI. Este, por sua vez, cliva o C3b em uma molécula enzimaticamente inativa, o iC3b, liberando um fragmento de $3 \mathrm{kDa}$, o C3f (MORGAN \& HARRIS, 1999).

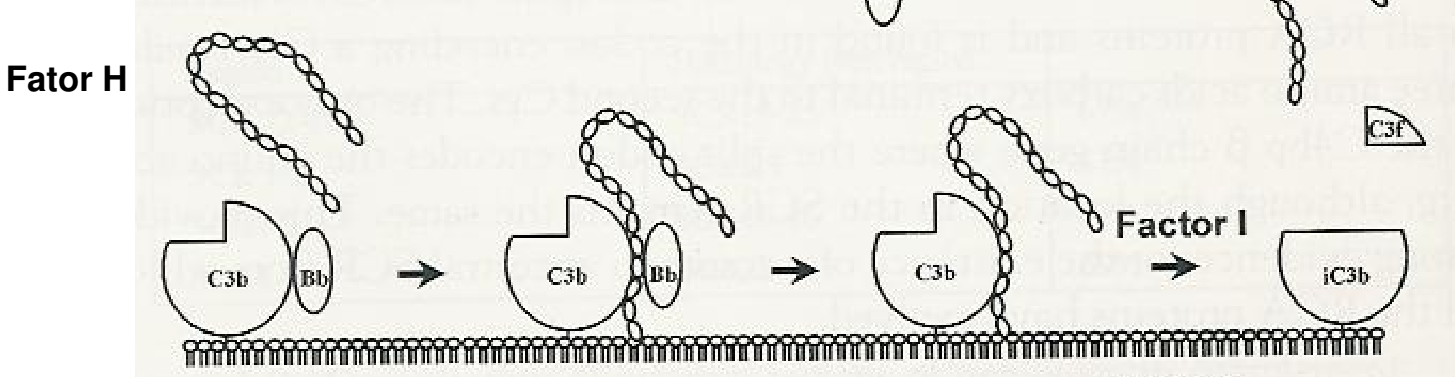

Figura 7: Representação esquemática da inibição da via alternativa pelo $\mathrm{FH}$. O FH se liga ao C3b impedindo ou desfavorecendo a associação dele com o FB e atua como co-fator na clivagem do C3b pelo FI, regulando a alça de amplificação da via alternativa. Modificado a partir de MORGAN \& HARRIS, 1999.

Mesmo sendo um regulador solúvel, o FH pode, ainda, regular a ativação do C sobre superfícies celulares, uma vez que possui a habilidade de discriminar superfícies ativadoras (não próprias) das não ativadoras (próprias) das cascatas do C. Esta habilidade lhe é atribuída 
pela sua capacidade de ligação a integrinas (CR3) e a poliânions, como ácido siálico (da mesma forma que proteoglicanos, sulfato de heparana, e glicosaminoglicanos), presentes na membrana das células próprias. A presença desses poliânions aumenta a afinidade do FH pelo C3b, impedindo a formação da C3 convertase e a conseqüente ativação do C sobre essa membrana (Figura 8). Quando em superfícies não próprias, superfícies despidas de poliânions, ou mesmo na fase fluida, o FH tem baixa afinidade pelo $\mathrm{C} 3 \mathrm{~b}$, permitindo, então, a sua ligação com o FB, a formação da C3 convertase e a amplificação da via alternativa (Figura 8) (GIANNAKIS et al, 2001).

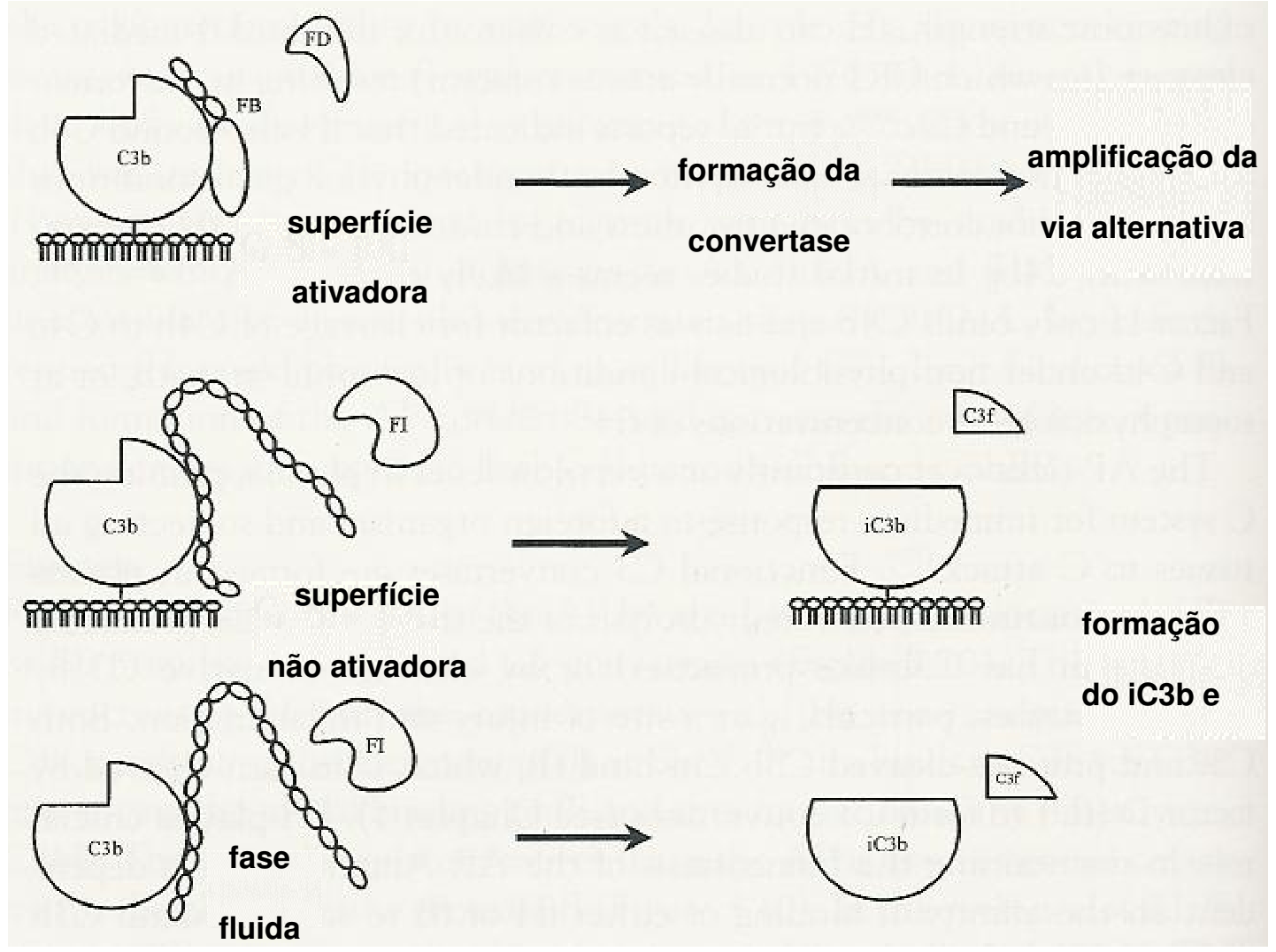

Figura 8: Representação esquemática da influência de superfícies ativadoras e não ativadoras do complemento na ligação do $\mathrm{FH}$ ao $\mathrm{C} 3 \mathrm{~b}$. O FH impede a amplificação da via alternativa sobre superfícies não ativadoras (próprias) e na fase fluida, mas não sobre superfícies ativadoras. Modificado de MORGAN \& HARRIS, 1999). 
Esta capacidade de ligação do FH a células próprias é de importância crucial para células que não expressam, ou expressam pouco, proteínas reguladoras da ativação do $\mathrm{C}$ em suas membranas, como as células da membrana basal do glomérulo. Durante a inflamação ou mesmo infecção, quando a ativação do $\mathrm{C}$ precisa ser rápida e maciça, essas células ganham um reforço adicional na manutenção de sua integridade, principalmente quando localizadas na vizinhança de um foco infeccioso (Figura 9) (JÓZSI et al, 2004).

A)

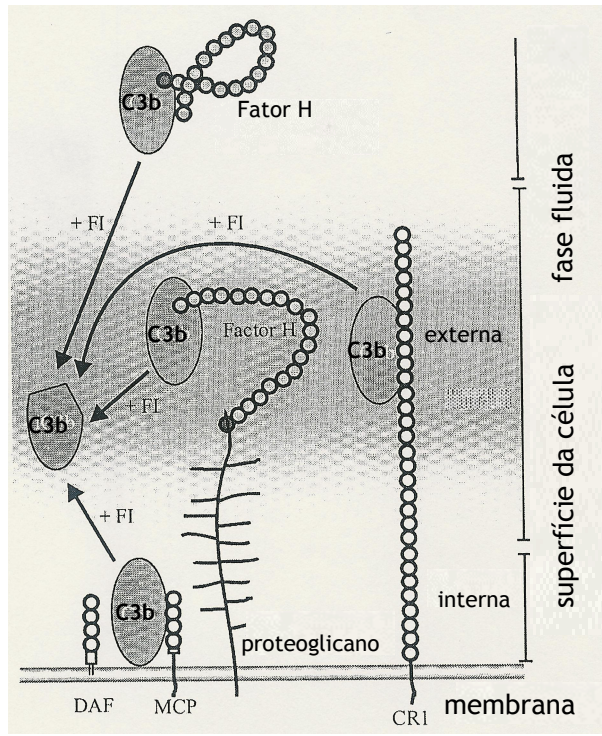

B)

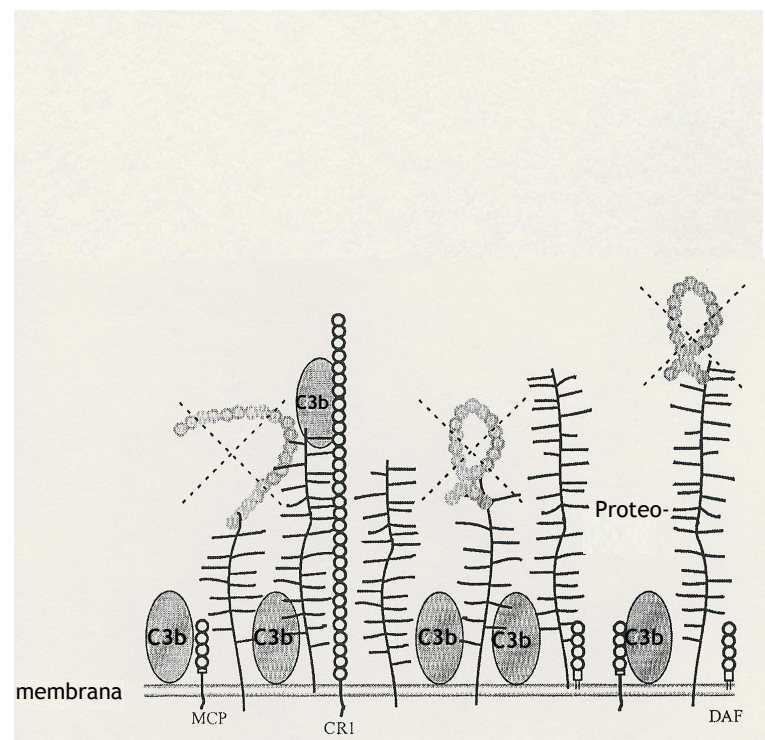

Figura 9: Modelo proposto para a ligação do FH a células endoteliais (Jozsi et al, 2004). A) Regulação da ativação do complemento na superfície endotelial mediada pelos reguladores de membrana e intensificada pelo FH ligado a proteoglicanos presentes na matriz extracelular. B) Modelo de regulação da ativação do complemento mediada pelo FH com mutações que interferem na sua ligação a proteoglicanos, muito comum em pacientes com síndrome hemolítico-urêmica. 


\section{DOMÍNIOS FUNCIONAIS DO FH}

Estudos aprofundados da estrutura do FH utilizando anticorpos monoclonais que bloquearam sítios específicos na proteína nativa ou mesmo estudos com deleções recombinantes em proteínas mutantes revelaram diferentes domínios da proteína envolvidos com funções distintas, exercidas pelo mesmo domínio, ou mesmo uma hierarquia de ligação dos domínios do FH com diferentes estruturas (Figura 5) (ZIPFEL et al, 1999a; ZIPFEL et al, 2001).

As funções de regulação da ativação do C como co-fator do FI, bem como de aceleração do decaimento da C3 convertase da via alternativa são desempenhadas pelos quatro SCRs da porção N-terminal da proteína (SCR-1 a -4) pela ligação ao C3b íntegro (GORDON et al, 1995; KUHN et al, 1995). Estudos subseqüentes revelaram a existência de sítios adicionais para ligação com a molécula de C3 nos seus diferentes fragmentos, SCRs-6 a -10 e 19-20, ligando C3c e C3d, respectivamente (SHARMA \& PANGBURN, 1996).

Por meio da sua propriedade de se ligar à heparina, o FH interage com as células próprias do indivíduo de maneira mais estável, através dos SCRs-7, -9 e -20 (BLACKMORE et al, 1996; PANGBURN et al, 1991; BLACKMORE et al, 1998; PRODINGER et al, 1998; ORMSBY et al, 2005). Já os SCRs-7 e 8-11 são capazes de se ligar à proteína C reativa (PCR) em reações de fase aguda (JARVA et al, 1999). Os autores sugerem que esta interação é importante para direcionar a atividade reguladora do FH sobre tecidos danificados após processo inflamatório (JARVA et al, 1999).

Através de seus SCRs-16 a -20, o FH pode ligar-se ao ácido siálico e a mucopolissacarídeos presentes nas membranas celulares próprias do organismo. Mesmo ligados, tanto o FH quanto o FHL-1 não perdem a sua capacidade de controlar a ativação do C na superfície em que se encontram. Desta forma, o FH desempenha um papel protetor 
importante para as células do corpo que não têm reguladores de membrana ou que os expressam em concentração muito reduzida (PERKINS \& GOODSHIP, 2002).

Aproveitando-se dessa capacidade do FH de ligar-se a membranas celulares e de nelas inibir a ativação do $\mathrm{C}$, alguns microorganismos desenvolveram meios para mimetizar as membranas celulares do hospedeiro e conseguir ligar-se ao FH/FHL-1, através dos SCRs-6 a 10, SCR-13 e SCRs-16 a -20, impedindo a ativação do C em suas membranas e a consequiente opsonização e lise (KRAICZY \& WÜRZNER, 2006) (Figura 5).

Há, ainda, relatos sobre a ligação do FH à integrina CR3 de neutrófilos humanos. Essa ligação desempenharia papel importante para a capacidade de adesão dessa célula, bem como para aumentar os sinais intracelulares de ativação, fazendo do neutrófilo uma célula mais eficiente (ZIPFEL et al, 1999a).

\section{A FAMÍLIA DE PROTEÍNAS DO FH}

A identificação de mais de um tipo de RNAm nas células hepáticas humanas que hibridavam com o cDNA do FH iniciou a busca por proteínas que exibissem algum grau de homologia com esta proteína (ZIPFEL \& SKERKA, 1994).

Em 1987, Schwaeble et al (SCHWAEBLE et al, 1987) isolaram dois RNAm diferentes $(4,4 \mathrm{~kb}$ e $1,8 \mathrm{~Kb})$ para a proteína $\mathrm{FH}$, expressos constitutivamente pelas células hepáticas. O primeiro RNA tinha o tamanho equivalente e adequado para codificação da proteína de $150 \mathrm{kDa}$, o $\mathrm{FH}$, enquanto que o RNA de 1,8 Kb correspondia a um produto de 43 kDa, hoje caracterizado e conhecido como FHL-1 (do inglês complement Factor H Like-1 protein) (Figura 10). Neste primeiro trabalho, eles levantaram a hipótese dessa proteína de 43 kDa ser produto de um splicing alternativo do gene $F H$ que levaria a um transcrito de $1,8 \mathrm{~kb}$, mas, somente em 1991, o mesmo grupo conseguiu provar essa hipótese (ESTALLER et al, 1991). 
A)

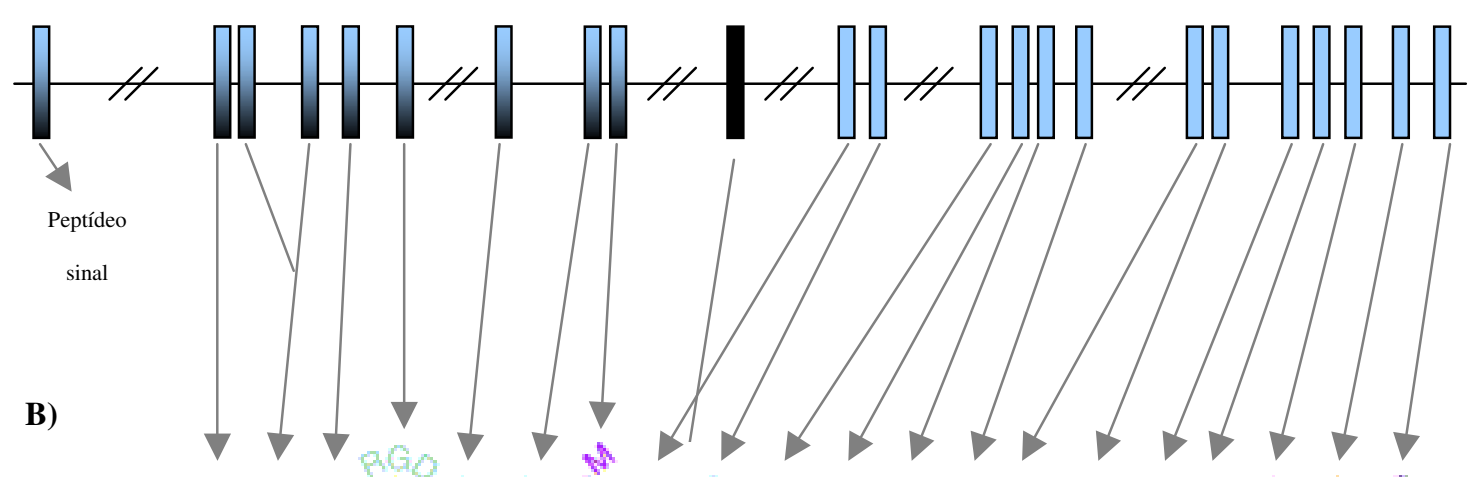

$\begin{array}{lllllllllllllllllllll}\text { FH } & 1 & 2 & 3 & 4 & 5 & 6 & 7 & 8 & 9 & 10 & 11 & 12 & 13 & 14 & 15 & 16 & 17 & 18 & 19 & 20\end{array}$

$\begin{array}{lllllllll}\text { FHL-1 } & 1 & 2 & 3 & 4 & 5 & 6 & 7 & - \text { SFLT }\end{array}$

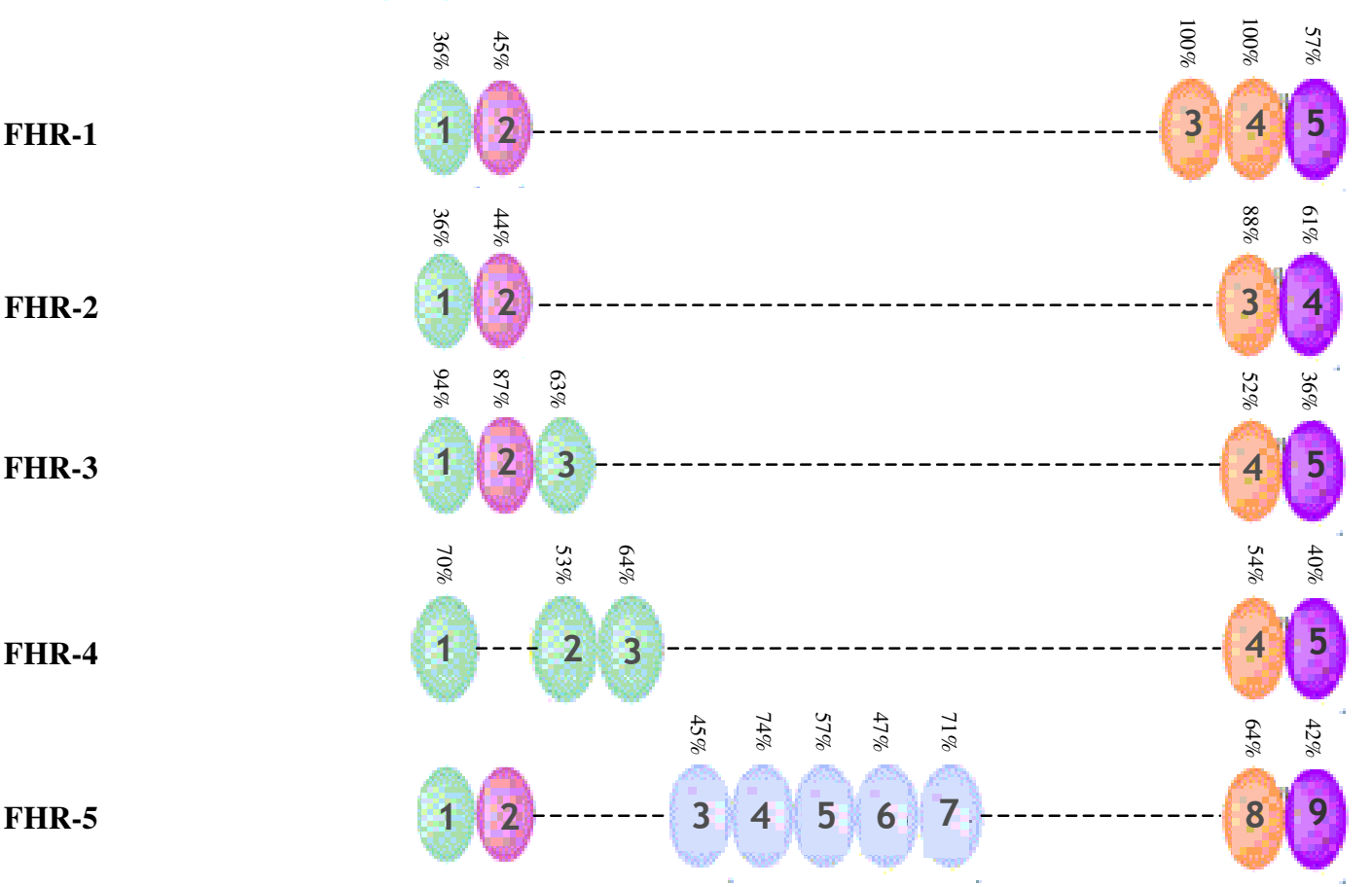

Figura 10: A família Fator H. Duas regiões do FH, SCRs-6 a -7 e SCRs-19 a -20, são as mais conservadas entre as demais proteínas, entretanto, com diferentes graus de homologia. A) Representação esquemática dos éxons do gene $F H$ e os respectivos SCRs por eles codificados; B) Representação esquemática das proteínas da família FH. SFLT: seqüência terminal de aminoácidos (Ser, Phe, Thr e Leu); RGD: seqüêcia de aminoácidos (Arg, Gly, Asp). Modificado a partir de ZIPFEL, 2001 e ZIPFEL et al, 2002. 
Estudos subseqüentes (SKERKA et al, 1991; SKERKA et al, 1992; SKERKA et al, 1993) revelaram a existência de proteínas adicionais, com diferentes pesos moleculares e graus de glicosilação, estruturalmente relacionadas ao FH.

A descoberta dessas proteínas tornou necessária a criação de uma nomenclatura sistemática e racional dessas proteínas e sua reunião em num mesmo grupo de proteínas, a família de proteínas FH. Assim, definiu-se como FHL-1 a proteína codificada por transcrito de RNAm originado por splicing alternativo do gene $F H$, enquanto que as FHRs (do inglês complement Factor $H$ Related proteins) são proteínas antigênica e estruturalmente relacionadas ao FH, mas codificadas por genes distintos (ZIPFEL \& SKERKA, 1994).

Agrupadas dessa forma a família Fator $\mathrm{H}$ exibe características que a torna um grupo único entre as proteínas plasmáticas humanas: 1) são as únicas proteínas plasmáticas organizadas estruturalmente apenas com domínios SCR; 2) todas são secretadas e/ou carregam na porção N-terminal um peptídeo que sinaliza uma possível secreção plasmática; 3) os SCRs exibem alto grau de homologia com os SCRs do FH; 4) as proteínas são antigenicamente relacionadas e reagem com anticorpos anti-FH (ZIPFEL et al, 1999b).

Atualmente, os membros da família Fator H compreendem desde um polipeptídeo idêntico ao FH a proteínas estrutural e antigenicamente relacionadas a ele (sete proteínas diferentes), sendo elas FH, FHL-1, FHR-1, FHR-2, FHR-3, FHR-4 e FHR-5 (ZIPFEL et al, 2002).

O FHL-1 
O FHL-1 é uma proteína solúvel de $43 \mathrm{kDa}$ codificada pelo mesmo gene $F H$, por meio de um splicing alternativo. Em virtude disso, o FHL-1 é idêntico aos primeiros sete SCRs da porção N-terminal do FH, e está presente no plasma nas concentrações de 10 a $50 \mu \mathrm{g} / \mathrm{mL}$, sendo o fígado a sua principal fonte (FRIESE et al, 1999).

O FHL-1 desempenha funções semelhantes às do FH na regulação da ativação do $\mathrm{C}$ e na capacidade de ligação a membranas celulares. O FHL-1 é capaz de funcionar como uma proteína de adesão, ao ligar fibroblastos pelo seu domínio RGD no SCR-4, facilitando o processo de "espraiamento" dessas células. Através do seu SCR-7, o FHL-1 pode também, como o FH ligar-se à heparina, presente nas membranas das células próprias, e à proteína M, expressa na membrana de microorganismos, principalmente estreptococos (ZIPFEL \& SKERKA, 1999).

\section{FHR-1 E FHR-2}

A proteína FHR-1 é encontrada no plasma humano em diferentes perfis de glicosilação. Assim, existem dois tipos de FHR-1: FHR-1 $\alpha$ com 37 kDa e FHR-1 $\beta$ com 42 $\mathrm{kDa}$, ambas com cinco SCRs, que apresentam alto grau de homologia com os SCRs-6 e -10 do FH (ZIPFEL et al, 2002).

Também para a proteína FHR-2 existem duas formas plasmáticas: FHR-2 como 24 kDa não-glicosilada e FHR-2a com 29 kDa, glicosilada. As duas formas são compostas por quatro SCRs e estes apresentam homologia com os SCRs-6 a 10 e -18 a -20 do FH (RODRIGUEZ DE CÓRDOBA et al, 2004).

Tanto as proteínas FHR-1 como as FHR-2 são codificadas por genes distintos do gene $F H$ e suas funções ainda não foram totalmente esclarecidas, tendo sido identificadas como 
participantes de complexos lipoprotéicos que aparentemente facilitam a resposta de neutrófilos ao LPS (ZIPFEL et al, 2002; MCRAE et al, 2005).

\section{FHR-3 E FHR-4}

O FHR-3 pode apresentar-se no plasma em cinco diferentes formas, pesando de 35 a $56 \mathrm{kDa}$ de acordo com o grau de glicosilação. É formado por cinco SCRs que apresentam alto grau de homologia com os SCRs da região intermediária e C-terminal do FH (ZIPFEL et al, 2002).

O FHR-4 é expresso no plasma somente na sua forma dimérica glicosilada com 86 kDa. Os SCRs apresentam o mesmo perfil de homologia que os SCRs do FHR-3 e também são em número de cinco (RODRIGUEZ DE CÓRDOBA et al, 2004).

Estudos mais aprofundados sobre as funções dessas duas proteínas revelam que ambas são capazes de ligar-se ao C3b e ao C3d. O FHR-3 pode ainda ligar-se à heparina e à proteína M presente nos estreptococos (BLACKMORE et al, 1998; KOTARSKY et al, 1998).

FHR -5

O FHR-5 é uma proteína de $65 \mathrm{kDa}$ identificada pela primeira vez em preparações de glomérulos humanos. Está presente no plasma na concentração de 3 a $6 \mu \mathrm{g} / \mathrm{mL}$ e é composta por nove SCRs que apresentam homologia com as proteínas FHR-1 e FHR-2, SCRs-1 e -2, respectivamente, e com os SCRs-10 a -14 e -19 a -20 do FH (MCRAE et al, 2005).

Em um estudo utilizando moléculas de FHR-5 recombinantes, McRae et al relataram que o FHR-5 é capaz de ligar C3b e heparina independentemente da presença de FH, bem como inibir a atividade da C3 convertase da via alternativa na fase fluida. Estudando a 
distribuição plasmática do FHR-5 descobriu-se sua associação com a HDL (do inglês highdensity lipoprotein) do plasma (MCRAE et al, 2005).

\subsubsection{Proteínas Reguladoras Ligadas à Membrana Celular}

A MCP (CD46) foi descoberta em 1985 durante estudo de proteínas ligantes de C3b e C4b em células mononucleares do sangue periférico (COLE et al, 1985). Com peso molecular variando entre $46 \mathrm{kDa}$ e $65 \mathrm{kDa}$ (a depender da isoforma), é uma glicoproteína transmembrana composta por quatro SCRs, que ao se ligarem ao $\mathrm{C} 3 \mathrm{~b}$ ou $\mathrm{C} 4 \mathrm{~b}$ facilitam a clivagem desses dois fragmentos pelo FI, por ser um dos co-fatores desse regulador (NANGAKU, 1998).

Além de seu papel na regulação do C, a MCP parece desempenhar outras funções adicionais. Alguns estudos afirmam a interação da $\mathrm{MCP}$ com a patogênese de vários microorganismos, como adenovírus e estreptococos, de forma que as células infectadas têm a expressão de MCP diminuída e aumentada a sensibilidade ao C (SCHNORR et al, 1995). Outros ainda, afirmam que a sinalização via CD46 nas células T leva essa linhagem celular a adquirir o fenótipo de célula reguladora (KEMPER et al, 2003). Há, ainda, um provável papel da MCP na reprodução e fertilização, uma vez que esta proteína está localizada na membrana interna do acrossoma dos espermatozóides (RILEY-VARGAS et al, 2004).

O DAF foi descoberto em 1969 por Hoffman ao inibir a lise de eritrócitos de carneiro e permanecer em soluções de extratos de hemácias humanas (LUBLIN \& ATKINSON, 1989). É uma glicoproteína de aproximadamente $70 \mathrm{kDa}$, composta por quatro SCRs (NICHOLSON-WELLER \& WANG, 1994) e que está ancorada às membranas de células sangüíneas, endoteliais e epiteliais através da ligação com moléculas de glicosilfosfatidilinositol (GPI) presentes nas membranas celulares (DAVITZ, 1987). 
A participação do DAF na regulação da ativação do C envolve a inibição da formação ou mesmo a aceleração do decaimento da atividade das C3 e C5 convertases das vias clássica e alternativa, por ligar-se ao C4b e ao C3b e impedir a associação destes com o C2a e o FB, respectivamente (NICHOLSON-WELLER \& WANG, 1994).

O CR1 é uma glicoproteína transmembrana de caráter polimórfico, com pelo menos quatro diferentes isoformas expressas (A, B, C e D), com pesos moleculares variando entre 190 kDa e 280 kDa. Em todas as isoformas, a porção extracelular é composta exclusivamente por SCRs, em número de cinco a oito a depender da isoforma expressa. Está presente em quase todas as células sangüíneas, com exceção das plaquetas, linfócitos NK e a maioria dos linfócitos T, enquanto nos tecidos pode ser encontrado nas células dendríticas e glomerulares (HOURCADE et al, 2000).

A função de regulador da ativação do C desempenhada pelo CR1 envolve o papel de co-fator na clivagem de $\mathrm{C} 3 \mathrm{~b}$ e $\mathrm{C} 4 \mathrm{~b}$ pelo FI em iC3b e iC4b e também na clivagem do iC $3 b$ em C3dg pelo mesmo regulador, além de aumentar a velocidade de decaimento da atividade das C3 e C5 convertases. Além da atividade de regulação do C, o CR1 atua como mediador na fagocitose de partículas opsonizadas pelo C3b. As partículas opsonizadoras (C3b) ligam-se ao CR1 presente na membrana das hemácias, que, então, transportam as partículas para o fígado ou baço, onde serão entregues aos macrófagos residentes (LISZEWSKI et al, 1996).

As proteínas HRF (do inglês Homologous Restriction Factor) e CD59 também se apresentam amplamente distribuídas pelo organismo, pelos mesmos motivos que o DAF. Estas proteínas apresentam propriedades semelhantes, pois ambas impedem os processos de formação do MAC ao se ligarem aos complexos C5b-8 ou C5b-9 (LEHTO et al, 1995; TANDON et al, 1992). 


\subsection{Deficiências do Sistema Complemento}

\subsubsection{Deficiência de Componentes da Via Clássica}

C1 é o primeiro componente desta via. É uma proteína de estrutura complexa composta por três subunidades: C1q, C1r e C1s. C1q é composto por 18 cadeias polipeptídicas dos tipos A, B e C ligadas entre si por pontes dissulfídicas. As três cadeias são codificadas por um gene $24 \mathrm{~kb}$ no cromossomo 1 . A deficiência de C1q está associada com o desenvolvimento de doença auto-imunes, como lúpus eritematoso sistêmico e glomérulonefrite, e maior susceptibilidade a infecções. C1r e C1s são codificados por genes distintos (mas próximos) localizados no cromossomo 12 e secretadas como proteínas de cadeia polipeptídica simples. A deficiência de C1r está geralmente associada com a deficiência parcial de $\mathrm{C} 1 \mathrm{~s}$, em virtude da proximidade desses dois genes. A deficiência dessas duas proteínas também está associada com o desenvolvimento de lúpus e aumento da susceptibilidade a infecções (PICKERING et al, 2000).

C4 é codificado por dois genes diferentes $C 4 A$ e $C 4 B$. As proteínas C4A e C4B codificadas pelos dois genes diferem entre si por apenas quatro aa na cadeia, sendo, entretanto, o C4B mais hemoliticamente ativo. Existe uma freqüência extremamente alta de polimorfismo e de alelos nulos nos genes $C 4$. Aproximadamente $35 \%$ da população mundial não expressa $\mathrm{C} 4 \mathrm{~A}$ ou $\mathrm{C} 4 \mathrm{~B}$. A deficiência completa de $\mathrm{C} 4$ é rara e está associada ao desenvolvimento de lúpus sistêmico ou discóide, bem como doença renal associada à deposição de complexos imune (BARBA et al, 1993).

C2 é uma proteína de cadeia polipeptídica simples de $84 \mathrm{kDa}$ codificada por um gene $14 \mathrm{~kb}$ situado nas proximidades de gene $F B$, cujo produto o $\mathrm{C} 2$ tem $35 \%$ de homologia. A deficiência de C2 é uma das deficiências do complemento mais comuns entre os caucasianos, aproximadamente $1-1,5 \%$ destes tem alelos nulos no gene $C 2$ e 1 em cada 10.000 tem deficiência completa da referida proteína. A deficiência completa de C2 tem sido associada 
com infecções piogênicas recorrentes, polimiosistes, púrpura e vasculites, além de lúpus eritematoso sistêmico, alteração mais comum.

\subsubsection{Deficiência dos Componentes da Via Alternativa}

O FD é uma serino-protease de $25 \mathrm{kDa}$ sintetizada principalmente nos adipócitos e macrófago (SCHIFFERLI \& MIOT, 2000). A deficiência completa de FD está associada a infecções recorrentes por microorganismos do gênero Neisseria e infecções respiratórias recorrentes (HIEMSTRA et al, 1989; BIESMA et al, 2001).

O FB é uma serino proteinase trilobular composta por 739 aa sintetizada principalmente no fígado e com peso molecular de $83 \mathrm{kDa}$ (ARLAUD et al, 1998). Existem apenas dados preliminares sobre a deficiência completa desta proteína (DENSEN, 1991) associando-a com infecções meningocócicas graves e recorrentes.

O C3 é uma molécula de aproximadamente $185 \mathrm{kDa}$ secretada inicialmente como uma molécula de cadeia única, o pró-C3, e que após modificações pós-translacionais passa a possuir duas cadeias ( $\alpha$ : $110 \mathrm{kDa}$ e $\beta: 75 \mathrm{kDa}$ ), ligadas entre si por pontes dissulfídicas, e uma

ligação tiól-éster na sua cadeia $\alpha$. É esta ligação que lhe confere a possibilidade de ligar-se covalentemente a moléculas aceptoras nas superfícies celulares (LAMBRIS \& MÜLLEREBERHARD, 1986).

O C3 é a proteína do C mais abundante no soro humano (aproximadamente 1200 $\mu \mathrm{g} / \mathrm{ml}$ ) e é também a mais central e versátil. Em virtude disso, o C3 desempenha diversos papéis essenciais para a ativação e/ou funções biológicas do $\mathrm{C}$ após clivagem nos seus diversos fragmentos: 1) formação das C3 e C5 convertases; 2) opsonização (através de seus fragmentos $\mathrm{C} 3 \mathrm{~b}$ e iC3b); 3) ativação dos linfócitos $\mathrm{B}$ e aumento da produção de imunoglobulinas (C3d e C3dg); 4) desgranulação de mastócitos e basófilos (C3a); 5) 
solubilização e remoção de complexos imunes $(\mathrm{C} 3 \mathrm{~b})$; 6) remoção de células apoptóticas (iC3b) (Revisado em WALPORT, 2001).

Diante de tantas funções desempenhadas pelo C3 não é surpreendente que a deficiência desta proteína esteja associada com infecções recorrentes graves e doenças mediadas por deposição de complexos imunes, principalmente glomerulonefite. Assim, dos 27 pacientes relatados como deficientes primários desta proteína, 13 foram acometidos por pneumonia, sinusite, tonsilite e otite e 9 por meningite. Sete deles tiveram, ainda, complicações renais, como glomerulonefrite masangiocapilar (REIS et al, 2006).

Existem, ainda, os pacientes com deficiência secundária de C3, nos quais a ausência dos reguladores $\mathrm{FH}$ e $\mathrm{FI}$, ou a presença dos fatores nefríticos $(\mathrm{FNe})$ de $\mathrm{C} 3$ e $\mathrm{C} 4$ (C3FNe e C4FNe - auto-anticorpos que estabilizam as C3 convertases das vias alternativa e clássica), leva a um consumo descontrolado de C3 e diminuição acentuada dos seus níveis plasmáticos. Assim, da mesma forma que nos deficientes primários de C3, pacientes com deficiência de FH ou FI também são muito susceptíveis a pneumonia e meningite, além de doenças causadas por deposição de complexos imunes, como lúpus e glomerulonefrite membranoproliferativa. Vale ressaltar que, apesar da semelhante predisposição a infecções encontrada tanto nos deficientes primários de $\mathrm{C} 3$ quanto nos deficientes de FH e FI, as doenças auto-imunes são mais freqüentes nos deficientes primários de C3, as infecções respiratórias e meningite nos deficientes primários de C3 e de FI, enquanto que as complicações renais são mais freqüentes nos deficientes de FH (REIS et al, 2006). Os fatores nefríticos, por sua vez, levam ao desenvolvimento de doenças renais, principalmente a glomerulonefrite do tipo III (DAHA et al, 1976). 


\subsubsection{Deficiência dos Componentes da Via Terminal}

As deficiências dos componentes C5, C6, C7, C8 e C9 são clinicamente caracterizadas pelo aumento da susceptibilidade a infecções pelo gênero Neisseria, ou seja, pacientes acometidos por esse tipo de deficiência são acometidos por meningite meningocócica recorrente, meningococemia aguda e crônica e/ou doença extragenital gonocócica (ALPER, 1987).

C5 é um heterodímero, com pontes dissulfídicas inter-cadeia, de aproximadamente 190 kDa e sua ausência impede a formação do MAC e a produção de C5a (Morgan \&Walport, 1991). Assim, a deficiência de C5 está associada com o aumento da susceptibilidade a infecções respiratórias, infecções graves por microorganismos do gênero Neisseria, otite, febre, além de sintomas mais inespecíficos como alopecia, hipopigmentação do couro cabeludo, crostas e eritema (ASGHAR et al, 1991; NIELSEN \& KOCH 1987). Sabe-se ainda que os soros de alguns indivíduos C5D não exibem atividade quimiotáxica para neutrófilos, provavelmente em virtude da produção diminuída de fragmentos C5a (ROSENFELD et al, 1976; SNYERMAN et al, 1979).

C6 e C7 são proteínas de cadeia única, ambas com $115 \mathrm{kDa}$, de estrutura e função muito semelhantes. A deficiência de C6 é a segunda mais freqüente entre os caucasianos (1:60.000), enquanto a de C7 é rara entre caucasianos, mas a segunda mais freqüente entre japoneses (1:25.000) (MORGAN \& WALPORT, 1991). Deficiências isoladas das duas proteínas já foram registradas na literatura e associadas a infecções por Neisseria $s p$ e doenças reumatológicas (COLTEN \& ROSEN, 1992).

C8 é uma proteína complexa formada por três cadeias ligadas entre si por ponte dissulfídica, $\alpha(64 \mathrm{kDa})$ e $\gamma(22 \mathrm{kDa})$, e por interações não covalentes, $\beta$ (64 kDa). Cada cadeia é codificada por um RNA diferente de dois cromossomos diferentes, 1p e 9q. Três tipos de deficiência de C8 já foram relatados na literatura: pacientes deficientes de cadeia $\alpha-\gamma$, 
pacientes deficientes de cadeia $\beta$ e pacientes com cadeia $\beta$ disfuncional, mas as características clínicas são idênticas para os três tipos de deficiência dessa proteína, tendo como principal manifestação o desenvolvimento de meningite meningocócica grave (COLTEN \& ROSEN, 1992).

\section{Deficiência de C9}

A deficiência congênita de C9 foi descrita pela primeira vez nos anos 70 (KIRA et al, 1998). É a deficiência do complemento mais comum no Japão, com incidência de um deficiente a cada mil pessoas (1:1000), mas é rara em outros países (ICHIKAWA et al, 2001).

Enquanto a deficiência congênita dos componentes da via terminal C5, C6, C7 e C8 sempre esteve associada com o aumento do risco de infecções por Neisseria sp, a deficiência do componente C9 estava aparentemente relacionada a indivíduos assintomáticos e saudáveis (KIRA et al, 1998). Entretanto, Nagata e seus colaboradores em 1989, estudando doadores de sangue em Fukuoka (NAGATA et al, 1989), demonstraram que o risco de pacientes deficientes de C9 desenvolverem infecções meningocócicas em relação a indivíduos normais era muito maior (KIRA et al, 1998).

Dos inúmeros estudos já realizados na população japonesa sobre deficiência de C9, um merece destaque especial, no qual Horiuchi et al em 1998 encontraram a mesma mutação C343T nos 10 pacientes estudados, gerando um códon de parada prematura no local da $\mathrm{Arg}^{95}$, seria a mutação mais freqüente responsável pela deficiência de C9 entre os japoneses. Em 8 dos 10 pacientes a mutação estava presente e nos dois restantes haviam mutações adicionais, C507Y e outra que não pôde ser determinada, que, associadas à mutação na $\operatorname{Arg}^{95}$ se responsabilizariam pela ausência da proteína nos soros do paciente (HORIUCHI et al, 1998). Os mesmos autores sugeriram que a presença desta mutação na posição da $\operatorname{Arg}^{95}$ possa ter estado presente entre os indivíduos fundadores desta população japonesa, possibilidade 
confirmada posteriormente por Khajoee et al (2003), quando eles encontraram a mesma mutação nas populações coreana e chinesa com uma frequiência de $2 \%$ e $1 \%$, respectivamente.

Outro estudo feito com uma família suíça deficiente em C9 (WITZEL-SCHLÖMP et $a l, 1997)$ mostrou ser esta dependente de duas outras mutações pontuais ambas encontradas concomitantemente nos dois pacientes estudados (heterozigotos) e ambas responsáveis pela geração de códons de parada prematura: uma localizada no éxon 2 (C166A) e outra no éxon 4 (C464T). O mesmo grupo realizou, ainda, outro estudo para avaliar as causas moleculares da deficiência de C9 em dois pacientes irlandeses não relacionados (WITZEL-SCHLÖMP et al, 1998). Eles encontraram a mesma mutação na posição 166 descrita no estudo anterior e uma substituição pontual (C350T) no éxon 4, como causas da deficiência no primeiro paciente. No segundo paciente, uma outra substituição pontual $C \rightarrow G$ na posição $1284(\mathrm{C} 1284 \mathrm{G})$ do éxon 9, levando a um códon de parada prematura na posição do aaminoácio 406, e uma substituição T359G no éxon 4, substituindo a Cys ${ }^{98}$ por uma Gly ${ }^{98}$ (WITZEL-SCHLÖMP et al, 1998) foram associadas à deficiência completa da proteína.

1.3.4 Deficiência de Proteínas Reguladoras da Ativação do Complemento

\subsubsection{Deficiência de Proteínas Reguladoras Solúveis}

A deficiência de C1-In foi descrita pela primeira vez em 1963 em pacientes acometidos por agioedema. Esta deficiência tem perfil hereditário autossômico dominante, uma exceção aos mecanismos de herança genética das deficiências de proteínas do complemento, e permanece associada a essa patologia até os dias de hoje. Diferentes perfis de alterações moleculares já foram descritos como causas dessa deficiência, desde mutações pontuais até grandes inserções e deleções, com conseqüente variação do fenótipo exibido pelos pacientes: níveis plasmáticos reduzidos do inibidor ou mesmo níveis normais, mas 
funcionalmente comprometidos deste regulador (PAPPALARDO et al, 2002; GOMPELS et $a l, 2005)$.

A deficiência de FI é um fenômeno raro e seus sinais clínicos são semelhantes aos apresentados na deficiência de FH: desenvolvimento de infecções por bacterianas piogênicas nos primeiros anos de vida, como meningite ou mesmo septicemia e aumento do risco de desenvolvimento de glomerulonefrite e doenças auto-imunes (NAKED et al, 2000; AMADEI et al, 2001; BARACHO et al, 2003; GENEL et al, 2005).

A deficiência de FI está normalmente associada com baixos níveis de C3 e C5, em virtude do consumo excessivo dessas proteínas na ausência de regulação da atividade das C3 e C5 convertases e, conseqüentemente a problemas na opsonização e formação do MAC na membrana de microorganismos, entretanto, o desenvolvimento de complicações renais, como a glomerulonefrite, não está normalmente associado com a deficiência desta proteína (VYSE et al, 1994). Recentemente, mutações no gene FI têm sido associadas com o desenvolvimento de Síndrome Hemolítico-Urêmica (DRAGON-DUREY \& BACCHI, 2005).

A deficiência de properdina foi relatada pela primeira vez em 1982 (SJÖHOLM et al, 1982) numa família sueca associada a uma infecção meningocócica fulminante. Mais de 100 casos de deficiência de properdina já foram descritos e três fenótipos principais da deficiência definidos. No primeiro fenótipo os indivíduos que têm níveis plasmáticos de properdina reduzidos, principalmente em decorrência de um códon de parada prematura nos éxons 4-6, enquanto no tipo II os indivíduos têm níveis entre 1-10\% ou mesmo normais da proteína, mas ela é incapaz de formar os oligômeros que normalmente caracterizam este regulador. Por fim, no fenótipo tipo III, os indivíduos têm níveis normais da proteína em oligômeros, entretanto, sem atividade de estabilização de convertases. Nos tipos II e III desta deficiência, alterações moleculares que levaram à substituição de um e/ou dois aa foram identificadas como as principais causas da deficiência (LINTON \& MORGAN, 1999; FIJEN et al, 1999) 


\section{DEFICIÊNCIA DE FH}

A deficiência completa de FH (homozigota) é um fenômeno raro, com apenas 22 casos de 12 famílias diferentes, relatados até agora na literatura. Os pacientes manifestam diferentes características clínicas e são originários de diversas populações, incluindo brancos, africanos, asiáticos, beduínos, americanos, entre outras (Tabela 1) (VYSE et al, 1994; AULT et al, 1997; DRAGON-DUREY et al, 2004; REIS et al, 2006). 

Existem poucos dados publicados sobre as mutações genéticas responsáveis pela deficiência de FH. Na primeira publicação, os autores estudaram a sequiência do cDNA e o DNA genômico do paciente e identificaram duas mutações nos códons para dois resíduos de cisteína, uma no SCR-9 e outra no SCR-16. As duas mutações T1679C (Cys ${ }^{518} \rightarrow$ Arg) e G2949A (Cys ${ }^{941} \rightarrow$ Tyr) modificam resíduos conservados de cisteína, que formam as pontes dissulfídicas que mantêm a estrutura terciária dos domínios de SCR (AULT et al, 1997). No estudo seguinte, o mesmo grupo analisou dois mutantes de FH (C518R e C941Y) produzidos artificialmente. Eles observaram que estes mutantes ficavam retidos no retículo endoplasmático celular, mostrando que a esta deficiência de $\mathrm{FH}$ era causada por um impedimento na secreção desta proteína pelas células do paciente (SCHMIDT et al 1999).

Um outro grupo estudou três pacientes italianos deficientes de FH e encontraram uma mutação nonsense (G638T) manifestada de forma homozigota, criando códons de parada prematura na posição 171 do SCR-3. Por se localizar nos primeiros códons codificadores da proteína, esta mutação é responsável pela ausência completa do FH e do FHL-1 (SÁNCHEZCORRAL et al 2000).

Mais recentemente, Dragon-Durey et al (2004) analisaram o gene $F H$ de dezesseis pacientes com síndrome hemolítico-urêmica (SHU) e todos apresentaram anormalidades nas formas homozigota ou heterozigota, envolvendo uma mutação nonsense ou códons para resíduos de cisteína no gene $F H$. 


\section{DOENÇAS RELACIONADAS À DEFICIÊNCIA DE FH}

\section{Glomerulonefrite Membranoproliferativa Tipo II}

A glomerulonefrite membranoproliferativa tipo II (MPGN II) é uma doença renal rara, caracterizada por proteinúria persistente, hematúria e síndrome nefrótica, mais comum em crianças.

A MPGN II está associada com a ativação desregulada da via alternativa e conseqüente hipocomplementenemia, com massivos depósitos de C3 nos capilares dos glomérulos. Alguns estudos relatam também a associação entre MPGN II e deficiência de FH em vários pacientes que desenvolveram essa patologia (WEST, 1994; MERI et al, 1992). Ault e seus colaboradores (1997) caracterizaram molecularmente um desses pacientes deficientes de FH que desenvolveram MPGN II com um ano de idade. Identificaram duas mutações pontuais que afetavam dois resíduos conservados de cisteína e, por isso, alteravam a conformação estrutural da proteína e impediam sua secreção no plasma (AULT et al, 1997).

Em um trabalho subseqüente, HEGASY et al (2002) observaram que porcos deficientes de FH desenvolveram MPGN II, com baixos níveis plasmáticos de C3, ativação excessiva do $\mathrm{C}$ e depósitos de C3 nos glomérulos. Os animais que tiveram seus níveis plasmáticos de $\mathrm{FH}$ reconstituídos à faixa normal sobreviveram à doença, enquanto os demais foram a óbito por falência renal (HEGASY et al, 2002).

Existem, ainda, relatos de pacientes que produziram auto-anticorpos contra o SCR-3 do FH, também chamados de proteína LOI, e desenvolveram MPGN II com características semelhantes às encontradas em deficientes de $\mathrm{FH}$ : hipocomplementenemia e massivos depósitos glomerulares de C3. Os autores acreditavam que, ao se ligar ao SCR-3 do FH e do FHL-1, este auto-anticorpo impedia suas atividades de regulação da ativação da via alternativa do C (ZIPFEL et al, 1999b; ZIPFEL, 2001). 


\section{Síndrome Hemolítico-Urêmica}

A síndrome hemolítico-urêmica (SHU) é caracterizada pela tríade: anemia hemolítica microangiopática, trombocitopenia e falência renal aguda. A doença é considerada rara e classificada em diarréica (forma "típica") e não diarréica (forma "atípica"). A forma típica afeta principalmente crianças e é caracterizada por diarréia com eliminação de sangue, causada pela Escherichia coli enterohemorrágica produtora de verotoxina/shigatoxina, principalmente a cepa 0157:H7. O prognóstico é normalmente bom com a completa recuperação da função renal. A forma atípica, por sua vez, pode apresentar-se na forma esporádica ou associada à herança genética, afeta crianças mais velhas ou adultos e tem prognóstico bem pior que o primeiro tipo, sendo a morte e danos permanentes, renais ou neurológicos, finais comuns para os pacientes acometidos por este mal (TAYLOR, 2001).

Níveis reduzidos de C3 em pacientes com SHU típica e atípica são registrados na literatura desde 1975 (KAPLAN et al, 1975), mas o primeiro registro associando essa patologia com baixos níveis de FH foi feito por Thompson e Winterborn em 1981 (THOMPSON \& WINTERBORN, 1981; ZIPFEL et al, 2001). Desde então, inúmeros estudos associando baixos níveis de $\mathrm{FH}$ ao desenvolvimento de SHU foram levados a efeito (dentre eles: PICHETTE et al, 1994; ROUGIER et al, 1998; OHALI et al, 1998) com níveis de proteína variando entre menos de $10 \%$ e $50 \%$ dos níveis encontrados em indivíduos normais. O mecanismo sugerido como responsável pela associação entre esses dois fatores envolve uma ativação desregulada das cascatas do complemento sobre tecidos próprios dos indivíduos deficientes de FH. Este prejuízo na regulação da ativação do complemento levaria ao surgimento das alterações encontradas na SHU (ZIPFEL, 2001; ZIPFEL et al, 2006; ZIPFEL \& SKERKA, 2006).

A deficiência da proteína reguladora predispõe ao desenvolvimento da SHU, entretanto, existem outros fatores considerados como desencadeadores etiológicos dessa 
patologia. No caso da forma típica afirma-se que este fator desencadeador seria a toxina produzida pela cepa específica de $E$. coli. Na forma atípica, existem vários fatores ambientais envolvidos, como gravidez, período pós-parto, uso de contraceptivo oral, indutores de mitose, tumores malignos e infecções (menos freqüente) (ATKINSON et al, 2005).

A seqüência de eventos envolvidos no desenvolvimento de SHU é iniciada quando os fatores etiológicos citados acima levam à lesão das células do tecido endotelial (Figura 11). Uma vez danificado, o tecido endotelial passa a induzir a ativação das cascatas do complemento, que, na presença de seus reguladores, seria benéfica e importante para o reparo tecidual. Todavia, na ausência de regulação apropriada as células endoteliais danificadas, passam a induzir os efeitos biológicos decorrentes da ativação completa das cascatas do complemento sobre as suas próprias membranas a partir da deposição do C3b. Assim, o C3b depositado servirá como ligante para células fagocitárias e os fragmentos C3a e C5a gerados sinalizarão positivamente para o recrutamento de células inflamatórias. Estas células inflamatórias, quando ativadas, liberarão mediadores pró-inflamatórios, como TNF $\alpha$ e IL-8, que, por sua vez, levam à retração do tecido endotelial e conseqüente exposição da camada subendotelial. A exposição do tecido subendotelial, deficiente em proteínas reguladoras ligadas à membrana celular, leva a uma intensificação na deposição de C3b e, conseqüentemente, a uma amplificação na ativação do complemento. Por fim, o MAC, induz a desestabilização ou mesmo lise das membranas celulares (ZIPFEL, 2001; ATKINSON et al, 2005). 


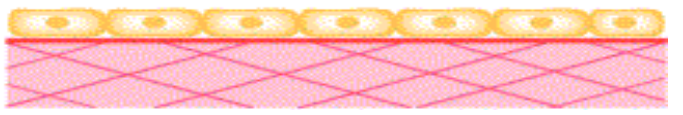

Matriz extracelular subendotelial

(b) Agente inflamatório
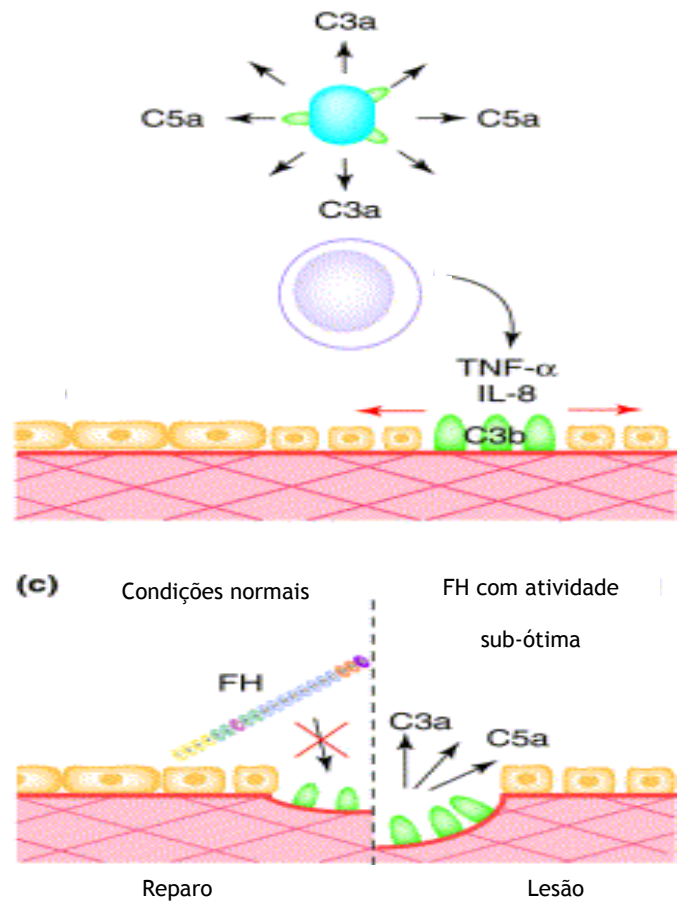

Figura 11: Seqüência de eventos que levam à lesão tecidual em pacientes com SHU e mutações no FH (ZIPFEL, 2001). A) Tecido endotelial intacto; B) Seqüência de eventos que levam ao dano tecidual; C) Regulação da ativação do complemento num indivíduo normal e num indivíduo com mutações no FH.

Corroborando com modelo sugerido acima, estudos moleculares conduzidos por Warwicker e seus colaboradores em 1998 (WARWICKER et al, 1998) identificaram uma área no cromossomo 1q32 diretamente associada com o desenvolvimento de SHU, região cromossômica onde está localizado o gene $F H$.

Análises mais aprofundadas revelaram, ainda, uma forte relação entre a alta incidência de mutações pontuais na região C-terminal do FH e pacientes acometidos pela SHU (YING et al, 1999; PÉREZ-CABALLERO et al, 2001; CAPRIOLI et al, 2001; RICHARDS et al, 2001; SÁNCHEZ-CORRAL et al, 2002). Sabe-se que esta região do FH é capaz de se ligar a 
poliânions presentes na superfície das células endoteliais dos vertebrados, o que poderia explicar porque estas células são protegidas da ativação autóloga do complemento sobre suas membranas (RICHARDS et al 2002). Esta hipótese tornou-se ainda mais contundente após a publicação do trabalho de Józsi e seus colaboradores (JÓZSI et al 2004), onde eles provaram que as células endoteliais do cordão umbilical se ligavam ao FH por meio do SCR-20. A presença de uma mutação nesta região impedia a ligação do $\mathrm{FH}$ a estas células e a conseqüente proteção desta contra a ativação do complemento. Este mecanismo de proteção é, provavelmente, importante para todos os tipos celulares, mas em especial para as células que expressam pouco ou nenhum regulador da ativação do complemento na sua membrana celular, como é o caso das células da membrana glomerular do rim. Este achado definitivamente revela uma ligação entre o desenvolvimento de SHU e a existência de mutações deletérias na região C-terminal do FH.

As mutações foram, então, classificadas por Perkins e Goodship (PERKINS \& GOODSHIP, 2002) em dois tipos distintos. O tipo I envolve mutações responsáveis por alterar a secreção e a velocidade de degradação da proteína, diminuindo, conseqüentemente, seu nível no plasma do paciente. O tipo II relaciona-se a mutações que não alteram o nível plasmático da proteína, mas sim suas características funcionais.

Inúmeros estudos destinados a identificar e caracterizar mutações no gene $F H$ associadas com o desenvolvimento de SHU foram desenvolvidos desde então por diferentes grupos e em distintas etnias. Até o momento, foram relatadas 59 mutações em 58 pacientes, que foram associadas ao desenvolvimento de SHU. Dessas mutações, 64\% são substituições missense ou nonsense, $11 \%$ são inserções ou deleções, $1 \%$ mutações de splicing e $22 \%$ são polimorfismos sem associação com a doença. Embora essas mutações estejam distribuídas por diferentes SCRs, a grande maioria delas concentra-se na porção C-terminal da proteína, SCRs 16-20, e 48\% nos SCRs 19-20 (revisado em ZIPFEL et al, 2003; SAUNDERS et al, 2006). 
Um resumo das mutações encontradas nestes estudos, bem como a localização de cada uma delas pode ser encontrado na Figura 12.

Apesar da direta associação entre a presença de alterações no gene $F H$ e o desenvolvimento de SHU, a inexistência de mutações no gene $F H$ em diferentes pacientes com SHU, bem como a penetrância incompleta da doença em pacientes com mutação no gene FH ou mesmo a associação entre mutações no gene $M C P$ e o desenvolvimento de SHU impulsionaram vários estudos moleculares destinados a aprofundar a associação entre mutações na região do cromossomo 1q32 e o desenvolvimento de SHU. Sabendo que essa região cromossômica engloba não só o gene $F H$ como também de outras proteínas, como gene $M C P$ e $F I$, não surpreende a compilação de dados recentes afirmando a associação de SHU não só com mutações no gene $F H$, como também com mutações nos gene $M C P$ e $F I$, presentes de forma independente ou em concomitância com mutações no gene $F H$ (NORIS $e t$ al, 2003; ESPARZA-GORDILLO et al, 2005; DRAGON-DUREY et al, 2005; ZIPFEL \& SKERKA, 2006; ESPARZA-GORDILLO et al, 2006; SAUNDERS et al, 2006). 



\section{Degeneração da Mácula Relacionada à Idade (DMRI)}

A mácula é a porção central da retina e responsável pela nossa visão detalhada e central dos objetos e pessoas. A degeneração dessa porção da retina relacionada à idade, conhecida por DMRI, é a principal causa de cegueira entre maiores de 60 anos. Este tipo de doença surge com o aparecimento de drusas resultantes do depósito de material de descarte (lipoproteínas) que se acumula entre a membrana basal (membrana de Bruch) e o epitélio onde se localizam as células fotoreceptoras.

Existem dois tipos de DMRI: "seca" e "úmida". A DMRI seca é caracterizada pela formação das "drusas" sob a mácula tornando-a mais fina e completamente ressecada. A maioria dos casos de DMRI é do tipo "seco", entre $85 \%$ e 90\%. Na DMRI "úmida" novos vasos sanguíneos são formados sob a mácula. Esses vasos aumentam de volume, progressivamente, e rompem, gerando tecido de cicatrização que invade a membrana de Bruch e danifica permanentemente a visão.

Existem vários fatores de risco atualmente associados com o desenvolvimento de DMRI: predisposição genética, fatores ambientais como fatores nutricionais e fumo, obesidade, níveis lipídicos, isquemia, senescência e oxidação. Mas se sabe que a incidência de DMRI aumenta espontaneamente com a idade (KLEIN et al, 1992).

Sabe-se que a DMRI desenvolve-se em ambiente inflamatório. A etiologia de uma reação inflamatória, por sua vez, sofre grande influência do grau de ativação do C e dos fragmentos formados em conseqüência dessa ativação. Assim, vários trabalhos têm mostrado que fragmentos do sistema complemento podem ser encontrados depositados nas drusas e no próprio ambiente da retina e a ativação deste sistema poderia ser um dos contribuintes da resposta inflamatória instalada nestas estruturas. Esta ativação pode ser regulada por proteínas encontradas no fluido intra-ocular como MCP, DAF e CD59 (SOHN et al, 2000), regulação 
observada tanto para a via clássica quanto alternativa nos humores vítreo e aquoso de um indivíduo normal.

A associação de DMRI com fatores genéticos é conhecida há algum tempo e, por meio de estudos familiais, sabe-se que, o cromossomo 1, mais especificamente na região 1q31, está implicado com a DMRI. Nesta região, coincidentemente localizam-se os genes da família do FH. Como conseqüência do Projeto Genoma Humano e do estudo de polimorfismo de único nucleotídeo (SNP, do inglês single nucleotide polymorphism), vários grupos norte-americanos e europeus (KLEIN et al, 2005; HAINES et al, 2005; EDWARD set al, 2005; ZAREPARSI et al, 2005; SOUIED et al, 2005; HAGEMAN et al, 2005; CONLEY et al, 2005) mostraram que uma determinada variante de $\mathrm{FH}$ (contendo $\mathrm{His}^{402}$, ao invés de $\mathrm{Tyr}^{402}$ ) poderia ser apontada como um dos marcadores genéticos relacionados com maior taxa de risco para desenvolver DMRI. Os estudos acima propuseram que indivíduos com um dos alelos codificando para $\mathrm{FH} \mathrm{His}^{402}$ tinham 2 a 5 vezes maior risco de desenvolver DMRI, do que indivíduos que tivessem os dois alelos codificando para $\mathrm{FH} \mathrm{Tyr}{ }^{402}$. Este risco aumentava para 5 a 7 vezes, se ambos os alelos codificassem para $\mathrm{FH} \mathrm{His}^{402}$. Interessante ressaltar que este polimorfismo localiza-se no SCR7 de FH, que é uma das regiões que se ligam a C3b, heparina e proteína de fase aguda inflamatória Proteína C-Reativa (Figura 7).

\subsubsection{Deficiência de Proteínas Reguladoras Associadas à Membrana Celular}

Diferentes estudos têm associado várias mutações no gene $M C P$ com $\mathrm{o}$ desenvolvimento da SHU. Essas mutações são divididas em dois grandes grupos: mutações que levam à diminuição da expressão de MCP nas membranas celulares e mutações que não alteram a expressão desta proteína. A maioria dos pacientes incluídos no primeiro grupo tem a expressão de MCP reduzida a 50\% do índice normal de expressão, com capacidade de ligação ao C3b também reduzida à metade. Já no segundo grupo, os pacientes apresentam níveis 
normais de expressão de MCP nas suas membranas celulares. Entretanto, na maioria dos indivíduos, essas proteínas têm suas capacidades funcionais muito prejudicadas, com perda da capacidade de ligação ao C3b e/ou C4b, bem como da atividade de co-fator do FI na clivagem de um ou dos dois fragmentos (revisado em RICHARDS et al, 2007).

A deficiência de DAF tem sido diretamente relacionada ao desenvolvimento da hemoglobinúria paroxística noturna (HPN). Estes pacientes apresentam hemólise intravascular mediada pelo $\mathrm{C}$ em consequiência da ausência do DAF nas membranas das células sangüíneas. As causas moleculares dessa deficiência foram determinadas como sendo mutações somáticas no gene do fosfatidilinositol da classe A, que é essencial para a formação das âncoras de GPI nas membranas celulares. Assim, esses indivíduos não são completamente deficientes de DAF, mas sim da ligação deste regulador às membranas celulares (KIM \& SONG, 2006).

A deficiência de CD59 está da mesma forma que na deficiência de DAF, associada ao desenvolvimento da HPN. Entretanto, existem relatos de indivíduos com alterações genéticas que levam à deficiência de CD59 que desenvolveram a HPN, enquanto que outros deficientes exclusivamente de DAF não desenvolveram a doença. Estes dados parecem implicar mais diretamente a deficiência de CD59 e não de DAF com o desenvolvimento de HPN (KIM \& SONG, 2006). 
Em virtude da existência de poucos casos de deficientes de FH descritos na literatura e ainda mais escassos estudos sobre suas possíveis causas moleculares; e sabendo da vital importância de tais estudos para o melhor entendimento das múltiplas atividades fisiológicas do $\mathrm{C}$, bem como das patologias associadas às deficiências de seus componentes, tornou-se de nosso interesse estudar e analisar geneticamente a deficiência de FH (detectada pelo grupo da Dra. Anete Grumach da Faculdade de Medicina da USP e inicialmente diagnosticada como deficiência do componente C3) encontrada pela primeira vez num paciente brasileiro e pela primeira vez na literatura em concomitância com a deficiência do componente C9. 


\section{II_HIPÓTESE E OBJETIVOS DO TRABALHO}

\subsection{Hipótese do Trabalho}

Pacientes com deficiência primária da proteína reguladora $\mathrm{FH}$ desenvolvem deficiência secundária do componente C3 e, possivelmente, de outros componentes da via alternativa. Podem, ainda, ser portadores de deficiência concomitante de outros componentes do $C$, por exemplo, $C 9$, de forma aparentemente não relacionada.

\subsection{Objetivos Gerais}

Caracterizar esta imunodeficiência (dupla), utilizando métodos de avaliação funcional e quantificação das proteínas do $\mathrm{C}$ presentes no soro do paciente e ainda estabelecer as possíveis causas moleculares da deficiência.

\subsection{Objetivos Específicos}

$\Rightarrow$ Avaliar a atividade funcional das vias de ativação mediadas pelas vias clássica e alternativa do C;

$\Rightarrow$ Determinar a concentração sérica do FH, C3, C9 e outras proteínas do sistema complemento;

$\Rightarrow$ Estabelecer se a deficiência do componente C3 encontrada no paciente é do tipo primário ou secundário;

$\Rightarrow$ Avaliar os aspectos estruturais das proteínas FH e C9;

$\Rightarrow$ Identificar possíveis mutações nos genes $F H$ e $C 9$ presentes no material genético do paciente, extraído de seus fibroblastos, responsáveis pela deficiência combinada;

$\Rightarrow$ Confirmar o padrão de herança genética das mutações encontradas nesta família deficiente. 


\section{III_DELINEAMENTO EXPERIMENTAL}

3.1 Delineamento Experimental para Determinação da Atividade Funcional das Vias de Ativação do C nos Soros do Paciente e de seus Familiares

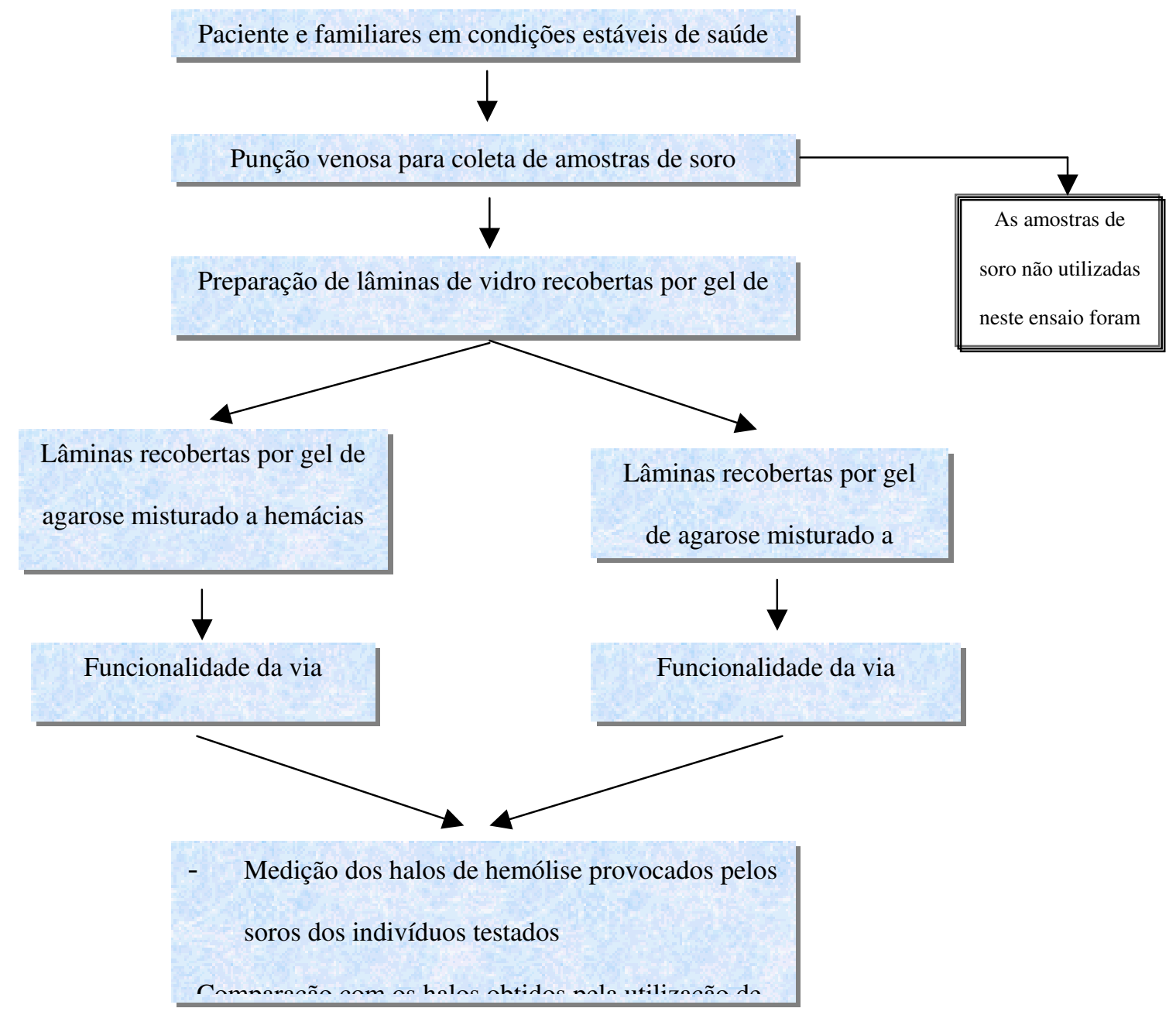


3.2 Delineamento Experimental para Determinar a concentração sérica do $\mathrm{FH}$, do $\mathrm{C} 9$ e do C3 nos Soros do Paciente e de seus Familiares

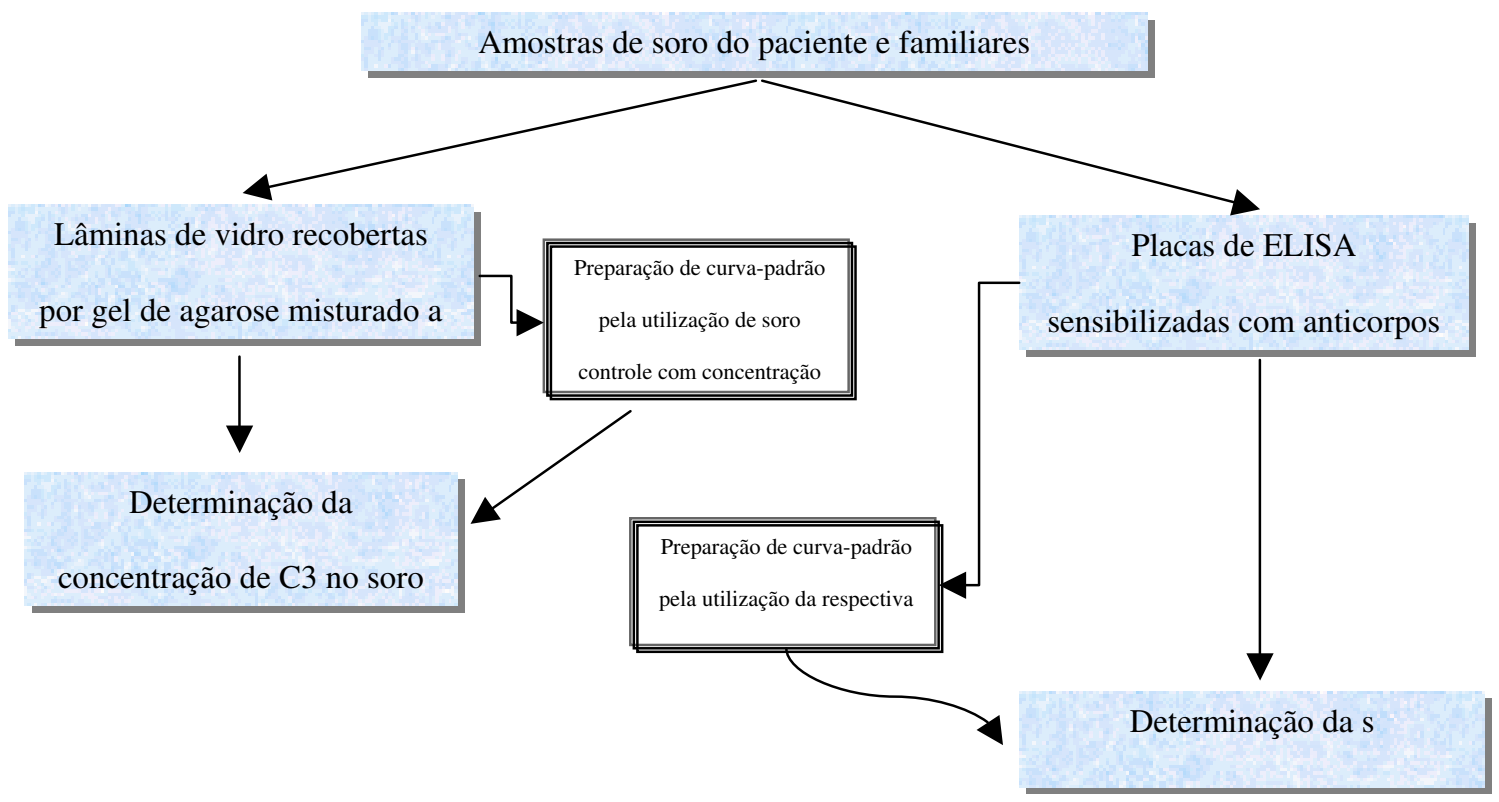




\subsection{Delineamento Experimental para Avaliação dos Aspectos Estruturais de Alguns}

Membros da Família FH e do C9

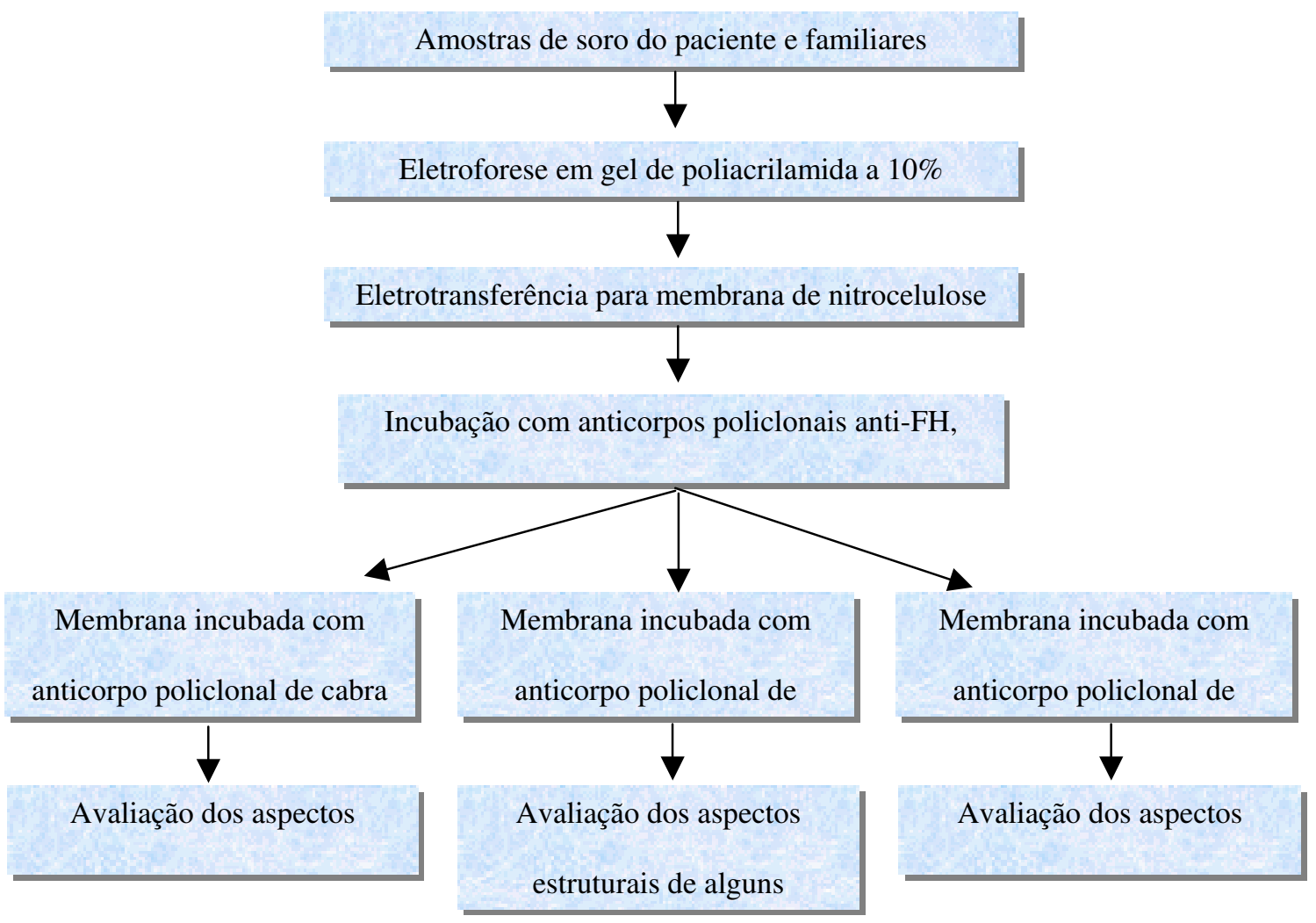




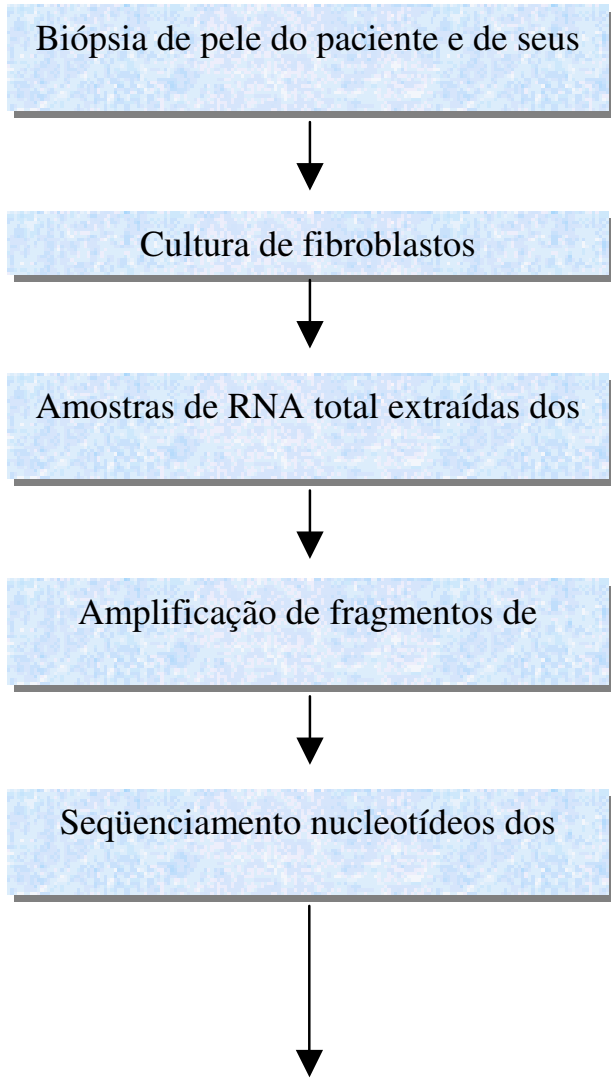
Amostras de DNA genômico extraídas

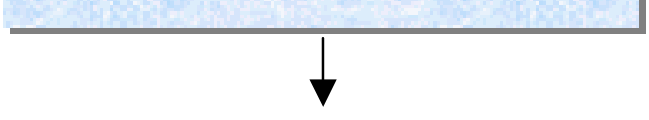

Amplificação dos fragmentos de DNA equivalentes às regiões do cDNA onde

Seqüenciamento dos nucleotídeos dos

- Confirmação da existência da mutação pela sua identificação no

DNA genômico do paciente 



\section{IV_MATERIAIS E MÉTODOS}

\subsection{Paciente}

De acordo com os dados fornecidos pela Dra. Anete S. Grumach, o paciente de 9 anos portador da deficiência de FH manifestou pneumonia com derrame pleural e necessidade de internação para drenagem torácica e uso de antibiótico endovenoso (Amoxicilina) aos 2 anos e 8 meses. Na ocasião, o paciente, que já havia recebido todo o programa vacinal recomendado pelo Ministério da Saúde, foi imunizado contra bactérias encapsuladas (meningo C e pneumo 23).

Aos 3 anos e 2 meses foi acometido por um novo episódio de pneumonia que evoluiu para insuficiência respiratória, necessitando de tratamento na Unidade de Terapia Intensiva, mas respondeu prontamente à antibioticoterapia, fato não observado anteriormente à vacinação para encapsulados. Não houve isolamento do agente etiológico responsável, entretanto, a imagem pulmonar mostrou condensação lobar, o que sugere infecção pelo pneumococo. Foi realizada, ainda, a avaliação da atividade hemolítica do soro do paciente pelas vias clássica (CH50) e alternativa (AP50), que se mostrou indetectável.

Ainda durante esse episódio foi feito um hemograma do paciente, cujos resultados se apresentaram dentro da normalidade (Tabela 2), e também uma avaliação imunológica do paciente, incluindo, dosagem de imunoglobulinas e subclasses de IgG, sorologia para sarampo, rubéola e HIV, pesquisa de anticorpos anti-pneumocócicos antes e após vacinação com pneumo 23 (23 sorotipos diferentes de pneumococos), fenotipagem de linfócitos e resposta proliferativa de linfócitos a mitógenos. 
Tabela 2: Valores dos parâmetros de hemograma avaliados no paciente*.

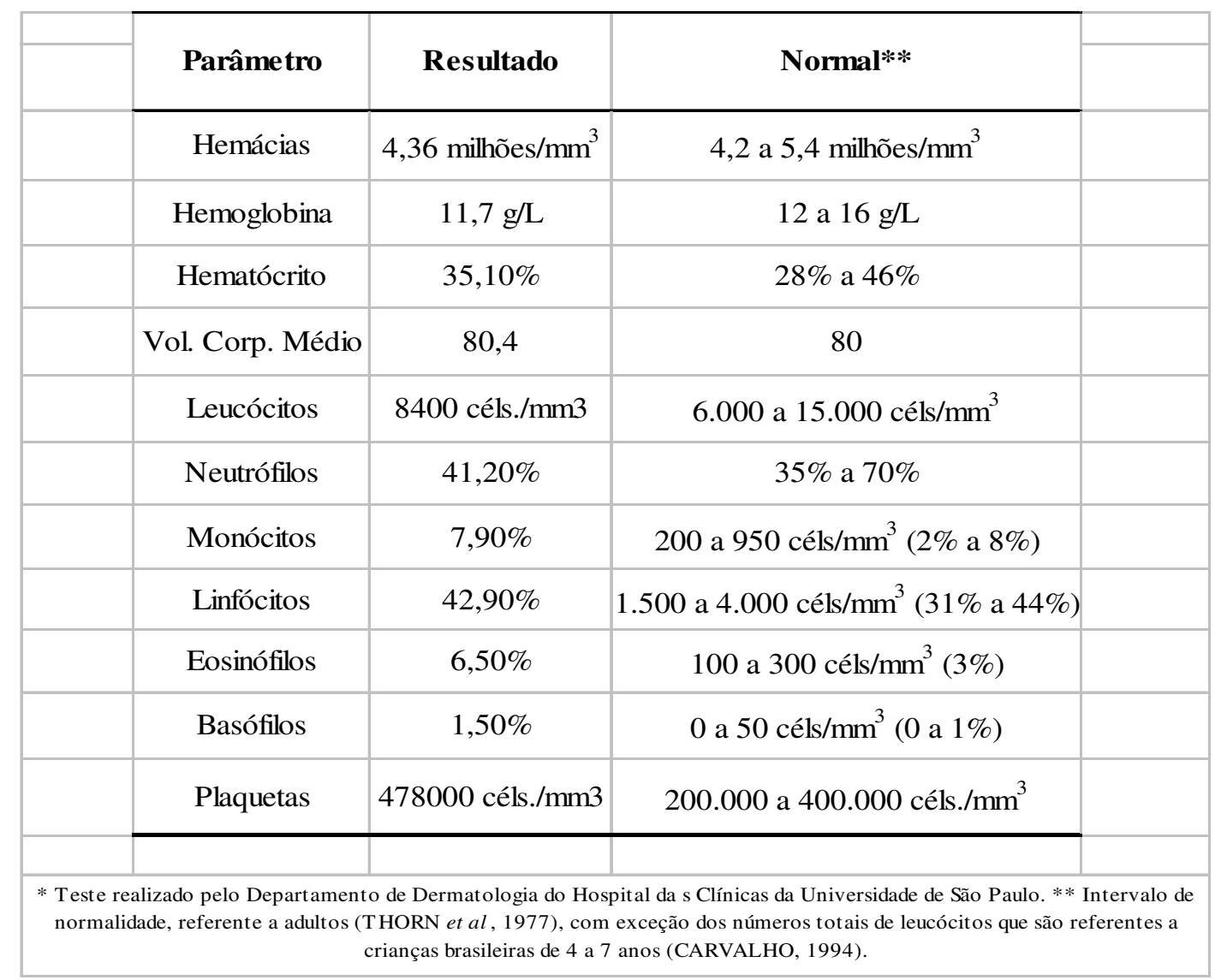

Foram dosadas as imunoglobulinas G, M e A (Tabela 3), bem como as subclasses de $\operatorname{IgG}$ 1, 2, 3 e 4, quando então não foi possível detectar a presença de IgG4 (Tabela 4). 
Tabela 3: Concentrações das classes de imunoglobulinas encontradas no soro do paciente*.

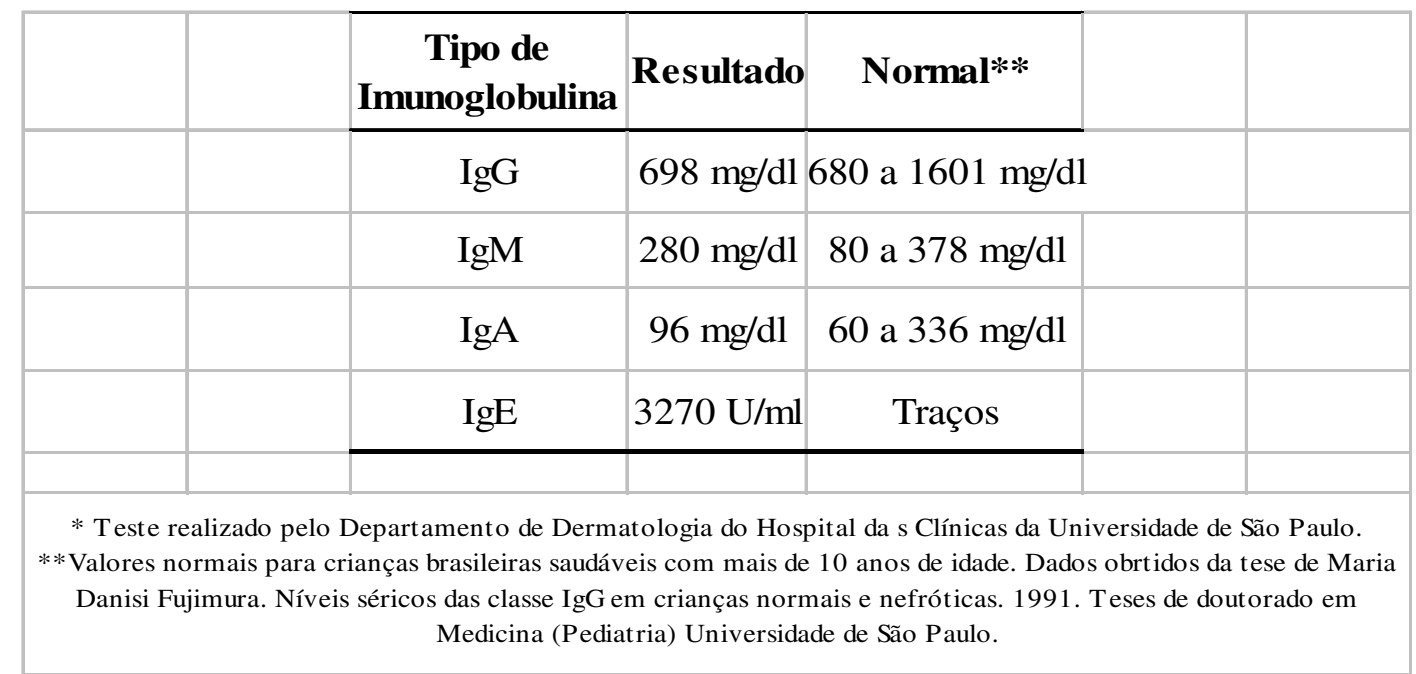

Tabela 4: Concentrações das subclasses de IgG encontradas no soro do paciente *.

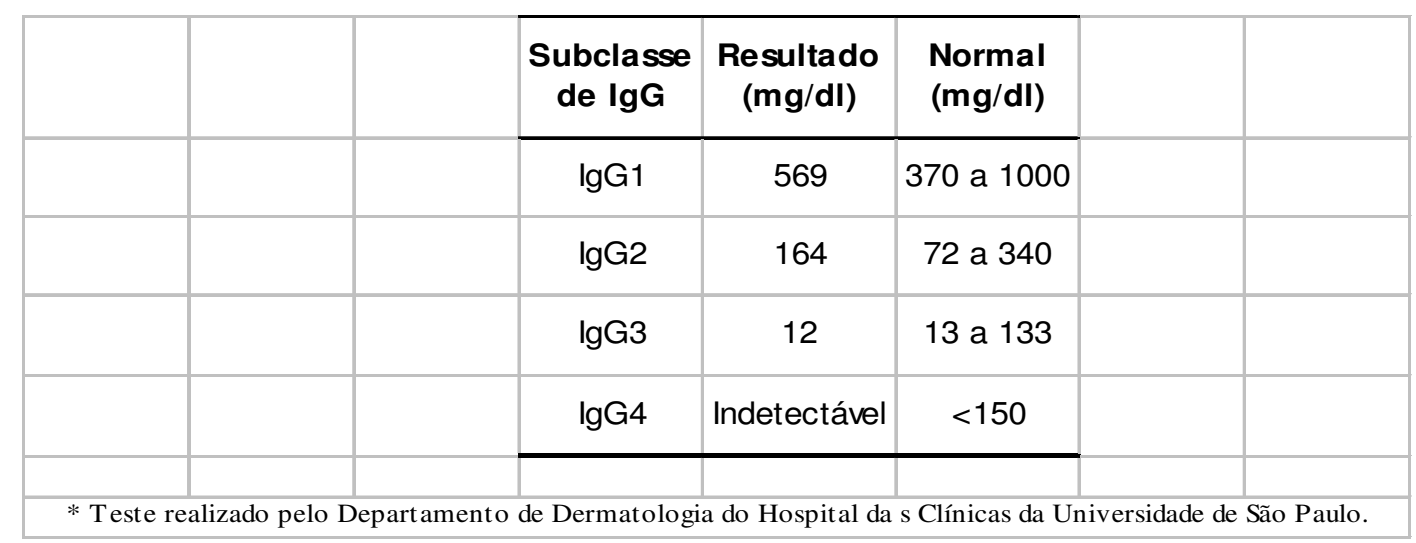

O restante da avaliação mostrou a presença de uma resposta positiva para a sorologia de rubéola, mas negativa para sarampo e HIV (Tabela 5), a existência subpopulações normais de linfócitos (Tabela 6), bem como uma resposta proliferativa normal dessas células a determinados mitógenos (Tabela 7) e uma resposta normal de anticorpos à vacina antipneumocócica (pneumo 23) (Tabela 8). 
Tabela 5: Avaliação da presença de anticorpos da classe IgM e IgG contra os agentes etiológicos da rubéola, sarampo e AIDS*.

\begin{tabular}{|l|c|c|c|c|c|c|c|}
\hline & $\begin{array}{c}\text { Tipo de } \\
\text { Sorologia }\end{array}$ & IgM & IgG & & & \\
\hline & & & & & \\
\hline & Rubéola & - & + & & & \\
\hline & Sarampo & - & - & & & \\
\hline & HIV & - & - & & & \\
\hline & & & & & \\
\hline
\end{tabular}

Tabela 6: Avaliação das subpopulações de linfócitos encontradas no soro do paciente*.

\begin{tabular}{|c|c|c|c|}
\hline & $\begin{array}{c}\text { Valor } \\
\text { Relativo (\%) }\end{array}$ & $\begin{array}{c}\text { Valor Absoluto } \\
\left.\text { (céls./mm } / \mathbf{m m}^{3}\right)\end{array}$ & $\begin{array}{l}\text { Normal } \\
\text { (céls/mm³) }\end{array}$ \\
\hline Leucócitos Totais & & 8.400 & \\
\hline Linfócitos & 44,4 & 3.730 & 2462 a 5323,6 \\
\hline Céls. $\mathrm{T} \mathrm{CD}^{+}$ & 70 & 2.611 & 1799,1 a 4034,7 \\
\hline Céls. T CD4 ${ }^{+}$ & 37,8 & 1.410 & 1113,8 a 2370,6 \\
\hline Céls. T CD8 ${ }^{+}$ & 25,1 & 936 & 658 a 1693,4 \\
\hline Céls. CD19 ${ }^{+}$ & 21,7 & 809 & 310 a 823,6 \\
\hline Céls. CD56 ${ }^{+}$ & 5,5 & 205 & 50 a 690 \\
\hline
\end{tabular}


Tabela 7: Avaliação da resposta proliferativa dos linfócitos do paciente a determinados mitógenos*.

\begin{tabular}{|c|c|c|c|}
\hline Mitógeno & $\begin{array}{c}\text { Índice de } \\
\text { Estimulação }\end{array}$ & $\begin{array}{c}\text { Valor de Referência } \\
\text { Percentil 5 }\end{array}$ & $\begin{array}{c}\text { Valor de Referência } \\
\text { Percentil 95 }\end{array}$ \\
\hline PHA & 42,49 & 18,2 & 343 \\
\hline OKT3 & 23,97 & 15,62 & 219,3 \\
\hline PWM & 124,43 & 8,42 & 107,4 \\
\hline
\end{tabular}

Tabela 8: Avaliação da produção de anticorpos anti-pneumococo pelo paciente após administração da vacina pneumo $23 *$.

\begin{tabular}{|l|l|l|l|l|l|l|}
\hline & Sorotipo & Ps1 & Ps5 & Ps6B & Ps8 & \multirow{2}{*}{} \\
\hline & Pré-vacinal & 3,9 & 8,22 & 2,43 & 3,83 & \\
\hline & Pós-vacinal & 5,18 & 8,77 & 2,91 & 5,75 \\
\hline & & & & \\
\hline & & & & \\
\hline
\end{tabular}

Após esses episódios graves de pneumonia o paciente tem sido mantido sob antibioticoterapia profilática com amoxicilina e não ocorreram novos episódios infecciosos. Exames de urina tipo I e ultrassonografias do abdômen (prevenção de SHU) têm sido realizados periodicamente como protocolo de monitoração do paciente.

Os pais do paciente são primos de primeiro grau e não manifestaram episódios infecciosos nem qualquer sintoma associado com a deficiência de FH. O casal possui, ainda, uma outra filha também saudável. 
O paciente foi inicialmente diagnosticado como deficiente do componente C3 pela Dra. Anete S. Grumach (Ambulatório de Manifestações Dermatológicas das Imunodeficiências Primárias e Laboratório de Investigação Médica em Dermatologia e Imunodeficiências, Faculdade de Medicina; Universidades de São Paulo) e posteriormente caracterizado por nós como deficiente da proteína reguladora $\mathrm{FH}$ em concomitância com o componente C9.

\subsection{Atividade Hemolítica mediada pela Via Clássica}

$\mathrm{O}$ ensaio hemolítico empregado para a via clássica do $\mathrm{C}$ é uma modificação da metodologia publicada por NILSSON \& NILSSON (1984).

Um volume de $4 \mathrm{ml}$ de hemácias de carneiro foi lavado em $6 \mathrm{ml}$ de tampão CFD (Complement Fixation Buffer- 4mM de Barbital de sódio; 145 mM cloreto de sódio; 830 mM cloreto de magnésio; $250 \mathrm{mM}$ cloreto de cálcio) e a mistura centrifugada por 5 min a 720 x $g$. O sobrenadante foi desprezado e as hemácias ressuspensas em CFD q.s.p. para $10 \mathrm{ml}$. O processo foi repetido mais duas vezes e as hemácias diluídas a 10\% em CFD.

Para sensibilizar as hemácias, $1 \mathrm{ml}$ de soro de coelho anti-carneiro (1:100) foi adicionado à suspensão, incubando-se a $4{ }^{\circ} \mathrm{C}$ por $30 \mathrm{~min}$. O processo de lavagem foi repetido por três vezes, como descrito acima, e a mistura ressuspensa em CFD q.s.p. para $10 \mathrm{ml}$. Um volume de $500 \mu \mathrm{L}$ dessa solução foi retirado e misturado a agarose a $1 \%$ em CFD. A mistura foi despejada sobre placas de vidro $(8 \mathrm{~cm} \times 8 \mathrm{~cm})$ e as placas colocadas em câmera úmida a 4 ${ }^{\circ} \mathrm{C}$ até o gel polimerizar por completo, quando então poços de $3 \mathrm{~mm}$ de diâmetro foram cortados no gel.

Uma mistura de soros de 47 indivíduos normais foi diluída em várias porcentagens $(100 \%, 75 \%, 50 \%, 25 \%$ e $12,5 \%)$ e utilizada para construção da curva-padrão. Um volume de 
7,5 $\mu \mathrm{L} /$ poço das amostras e de cada uma das diluições da curva padrão foi aplicado e colocado pra difundir no gel por $18 \mathrm{~h} \mathrm{a} 4{ }^{\circ} \mathrm{C}$. Em seguida, a placa foi incubada em estufa a 37 ${ }^{\circ} \mathrm{C}$ por 90 min e o tamanho dos halos de hemólise medido.

\subsection{Atividade Hemolítica mediada pela Via Alternativa}

O ensaio hemolítico empregado para avaliação da via alternativa do C é uma modificação da metodologia publicada por NILSSON \& NILSSON (1984).

Um volume de $4 \mathrm{ml}$ de agarose $(1 \%)$ foi misturado a 5,1 $\mathrm{ml}$ de GVB-EGTA-Mg${ }^{2+}$ (143,4mM de cloreto de sódio; 0,96 mM de barbital de sódio; 2,5 mM de barbital; 2mM de magnésio; $8 \mathrm{mM}$ de EGTA) a $56^{\circ} \mathrm{C}$. Em seguida foram adicionados (a $\left.45^{\circ} \mathrm{C}\right) 500 \mu \mathrm{L}$ de uma suspensão de hemácias de cobaia a $10 \%$ (previamente lavadas em GVB-EGTA-Mg ${ }^{2+}$, semelhante ao realizado para a via clássica) e a mistura despejada em placas de vidro $(8 \mathrm{~cm} \mathrm{x}$ $8 \mathrm{~cm}$ ), que foram colocadas em câmera úmida a $4{ }^{\circ} \mathrm{C}$ até a polimerização do gel. As placas foram retiradas da geladeira e poços de $3 \mathrm{~mm}$ de diâmetro cortados no gel.

Uma mistura de soros de 47 indivíduos normais foi diluída em várias porcentagens $(100 \%, 75 \%, 50 \%, 25 \%$ e $12,5 \%)$ em tampão PBS/EGTA/ $\mathrm{Mg}^{2+}$ e utilizada como curvapadrão. Um volume de 7,5 $\mu \mathrm{L} /$ poço das amostras e de cada uma das diluições da curva padrão foi aplicado e colocado pra difundir no gel $18 \mathrm{~h} \mathrm{a} 4{ }^{\circ} \mathrm{C}$. Em seguida, a placa foi incubada em estufa a $37^{\circ} \mathrm{C}$ por 90 min e o tamanho dos halos de hemólise formados avaliado.

\subsection{Imunodifusão Radial}

O método de imunodifusão radial (Mancini et al, 1965) foi utilizado para determinar as concentrações de C3, C4, FB, Properdina e FI nos soros do paciente e de seus familiares em comparação com as concentrações dessas proteínas encontradas nos soros de indivíduos normais (Ferriani et al, 1999; Ferreira de Paula et al, 2001). 
Foram utilizadas placas de vidro $(8 \mathrm{~cm} \times 8 \mathrm{~cm})$ recobertas por uma camada $(\sim 1 \mathrm{~mm})$ de agarose a $1 \%$ em PBS (1,6 mM de fosfato de sódio monobásico; $15 \mathrm{mM}$ de fosfato de sódio bibásico; $140 \mathrm{mM}$ de cloreto de sódio) contendo $2 \%$ de soro policlonal feito em cabra (Calbiochem) contendo anticorpos específicos para cada proteína.

Após solidificação do gel foram cortados orifícios de $3 \mathrm{~mm}$ de diâmetro, onde foram aplicados $5 \mu \mathrm{L}$ das amostras, em duplicada. Após $24 \mathrm{~h}$ de difusão a $4{ }^{\circ} \mathrm{C}$ em ambiente úmido, as lâminas foram submergidas em solução salina ( $0,15 \mathrm{M}$ de cloreto de sódio) por mais $24 \mathrm{~h}$ a $4{ }^{\circ} \mathrm{C}$. Após esse período, as amostras foram secadas em estufa a $37{ }^{\circ} \mathrm{C}$ por $48 \mathrm{~h}$, coradas em solução de Coomassie Blue (1mM de Comassie Blue, $10 \%$ de ácido acético glacial e $45 \%$ de etanol P.A.) por 20 min e descoradas por 15 min em solução descorante (10\% de ácido acético glacial e $25 \%$ de etanol P.A.).

Uma mistura de soros de 47 indivíduos normais, com concentração conhecida de C3, C4, FB, Properdina e FI, foi empregada em diferentes diluições, para estabelecimento de uma curva-padrão. A partir dela as concentrações das proteínas nos soros do paciente e de seus familiares foram extrapoladas por regressão linear.

\subsection{Imunodifusão dupla}

Utilizando a imunodifusão dupla (Ouchterlony \& Nilsson, 1978) avaliamos de forma semi-quantitativa as proteínas C5, C6, C7, C8 e C9 nos soros dos pacientes e de seus familiares diluídos de 1:2 a 1:32 seriadas em PBS.

Após $48 \mathrm{~h}$ de difusão a $4{ }^{\circ} \mathrm{C}$, as lâminas foram lavadas e coradas como descrito anteriormente para a imunodifusão radial. Os resultados foram avaliados de acordo com a formação de uma linha visível de precipitação entre os poços contendo o soro e o poço contendo o anticorpo específico. 


\subsection{Enzyme-linked Immunosorbent Assay (ELISA)}

\subsubsection{ELISA para FH}

O anticorpo policlonal anti-FH feito em coelho $(13,6 \mathrm{mg} / \mathrm{ml}$ - gentilmente cedido pela Dra. Pilar Sánchez-Corral, Hospital Universitario La Paz, Madri, Espanha) foi diluído no tampão contendo 0,1M bicarbonato/carbonato de sódio, $\mathrm{pH}$ 9,6, na concentração de 3,4 $\mu \mathrm{g} / \mathrm{ml}$ e adicionado à placa de ELISA (96 poços - $100 \mu \mathrm{L} /$ poço) por $18 \mathrm{~h}$ a $4{ }^{\circ} \mathrm{C}$. Após cinco lavagens com $200 \mu \mathrm{L} /$ poço de PBS-Tween (1,6 mM de fosfato de sódio monobásico; $15 \mathrm{mM}$ de fosfato de sódio bibásico; $140 \mathrm{mM}$ de cloreto de sódio; 0,05\% de Tween 20), foi realizado o bloqueio com leite desnatado a $5 \%\left(200 \mu \mathrm{L}\right.$ /poço) em PBS-Tween por $1 \mathrm{~h}$ a $37{ }^{\circ} \mathrm{C}$ (A partir deste momento, todos os soros e anticorpos foram diluídos em tampão PBS-Tween e incubados (100 $\mu \mathrm{L} /$ poço $)$ a $37^{\circ} \mathrm{C}$ por $\left.1 \mathrm{~h}\right)$.

Terminado o bloqueio e realizado mais um ciclo de lavagens, foram adicionados os soros do paciente e de seus familiares diluídos a 1:2000, 1:4000 e 1: 8000, além de um pool de soro humano normal diluído a 1:2000, 1:4000, 1:8000 e 1:16000 e da proteína FH purificada (Calbiochem - Novachem) em diferentes concentrações $(0,06 \mathrm{ng} / \mathrm{ml}$ a $1000 \mathrm{ng} / \mathrm{ml})$. Após a incubação e lavagens o anticorpo policlonal anti-FH feito em cabra (Calbiochem Novachem) diluído a 1:4000 foi adicionado. Finda a incubação e novo ciclo de lavagens foi realizada a incubação com o anticorpo terciário, anti-IgG de cabra policlonal conjugado com fosfatase alcalina (Calbiochem - Novachem), diluído a 1:5000.

Após novo ciclo de lavagens foi realizada a etapa de revelação, adicionando 200 $\mu \mathrm{L} /$ poço de uma solução de $p \_N P P$ (para-nitrofenil fosfato) a $1 \mathrm{mg} / \mathrm{ml}$ em tampão para fosfatase alcalina $(0,1 \mathrm{M}$ de dietanolamina; $0,02 \%$ de azida sódica; $0,5 \mathrm{mM}$ de cloreto de 
magnésio - pH 9,8). Passados aproximadamente 35 min a leitura das absorbâncias foi feita em leitor de ELISA a $405 \mathrm{~nm}$.

O método ELISA sanduíche para avaliação da concentração do FH estabelecido em nosso laboratório teve como limite mínimo de detecção a concentração de $0,24 \mathrm{ng} / \mathrm{ml}$ e como limite máximo $125 \mathrm{ng} / \mathrm{ml}$. A curva padrão com a proteína purificada foi construída e o valor de $\mathrm{R}^{2}$ obtido foi de 0,99 .

As amostras foram testadas em triplicata e os valores das absorbâncias obtidos com os soros diluídos a 1:8000 foram os escolhidos para determinação da concentração de FH nos soros do paciente e de sua família.

\subsubsection{ELISA para C9}

O ELISA para determinação da concentração da proteína C9 no soro do paciente e de seus familiares foi estabelecido com pequenas diferenças em relação às condições definidas para o ELISA de detecção da proteína FH. Assim, as particularidades citadas a seguir são as únicas distinções entre o ELISA estabelecido para FH e o estabelecido para C9.

O anticorpo policlonal anti-C9 feito em cabra (Calbiochem) foi diluído a 1:1000 e usado para sensibilizar a placa de ELISA.

A etapa de bloqueio foi realizada pela adição de $200 \mu \mathrm{L}$ de Soro Fetal Bovino inativado (SFBi) em cada poço da placa e incubação por $1 \mathrm{~h}$ a $37^{\circ} \mathrm{C}$. A partir desta etapa todos os soros e anticorpos foram diluídos em SFBi.

Os soros e a proteína $\mathrm{C} 9$ purificada foram diluídos e incubados por $2 \mathrm{~h}$ a $37^{\circ} \mathrm{C}$. Após a incubação com as amostras, o anticorpo policlonal anti-C9 feito em coelho (Serotec) foi diluído a 1:2000 e usado como anticorpo secundário. 
O método ELISA sanduíche para avaliação da concentração de C9 estabelecido em nosso laboratório teve como limite mínimo de detecção a concentração de 1,95 ng/ml e como limite máximo $125 \mathrm{ng} / \mathrm{ml}$. A curva padrão com a proteína purificada foi construída e o valor de $\mathrm{R}^{2}$ obtido foi de 0,99 .

As amostras foram testadas em triplicata e os valores das absorbâncias obtidos com os soros diluídos a 1:2000 foram os escolhidos para determinação da concentração de C9 nos soros do paciente e de sua família.

\subsection{Western Blot}

As amostras foram submetidas à análise em SDS-PAGE. Findada a corrida, o gel e algumas folhas de papel de filtro foram embebidos em tampão de transferência (Tris-Cl pH 7,5 48 mM, glicina 39 mM, dodecilsulfato de sódio 0,037\% (p/v), metanol 20\%). Feito isto, o gel foi posto sobre uma membrana de nitrocelulose e esta sobre uma camada de 3 folhas de papel de filtro que, por sua vez, repousam sobre um eletrodo. Para finalizar este processo, mais uma camada de folhas de papel de filtro foi colocada diretamente sobre o gel. Esse material foi, então, submetido a uma corrente de $0,8 \mathrm{~mA} / \mathrm{cm}^{2}$ de membrana durante $4 \mathrm{~h}$. Após a eletrotransferência, a membrana de nitrocelulose foi lavada em água Milli-Q e corada em solução de Ponceau S 0,1\% (p/v) em ácido acético 10\% (v/v) por 1 min. O excesso de corante foi retirado após lavagens sucessivas com água Milli-Q. Em seguida, a membrana foi lavada com tampão TBST [Tris-Cl pH 8,0 5,0 mM, NaCl 75 mM, Tween 20 0,028\% (v/v)] e incubada por aproximadamente 18 h, sob agitação, em solução de albumina a 3\% no mesmo tampão, à temperatura ambiente. Após o tempo determinado, foram feitas 3 lavagens com o próprio tampão, para retirar o excesso de albumina. Neste momento, foi realizada a incubação com o primeiro anticorpo (anticorpo policlonal anti-FH feito em coelho - gentilmente cedido pela Dra. Pilar Sánchez-Corral), diluído a 1:5000 em $25 \mathrm{ml}$ do tampão TBST, por 2h à 
temperatura ambiente, sob agitação. Novas lavagens foram feitas e, então, realizada a incubação com o segundo anticorpo (1:10.000) (anticorpo policlonal anti-IgG de coelho marcado com fosfatase alcalina - Calbiochem) em condições semelhantes às da incubação anterior. Finalmente, após novas lavagens, foi realizada a etapa de revelação das bandas, por meio da incubação da membrana com $10 \mathrm{ml}$ de solução APB $(\mathrm{NaCl} 100 \mathrm{mM}$, Tris-Cl pH 9,5 $100 \mathrm{mM}, \mathrm{MgCl}_{2} 5 \mathrm{mM}$ ), acrescida de $6 \mu \mathrm{L}$ de nitroazul tetrazólico [NBT, Nitro Blue Tetrazolium) a 0,3 $\mathrm{mg} / \mathrm{ml}$ (preparado em formamida $70 \% \mathrm{v} / \mathrm{v}$ )] e de $3 \mu \mathrm{L}$ de 5 -bromo-4-cloro3-indolil fosfato $0,15 \mathrm{mg} / \mathrm{ml}$ (preparado em formamida 100\%). O processo de revelação foi interrompido ao lavar a membrana com água Milli-Q, quando o nível de coloração desejado foi atingido.

\subsection{Cultura de Fibroblastos da Pele}

Os fibroblastos foram obtidos a partir de fragmentos $\left(3 \mathrm{~mm}^{2}\right)$ de pele retirados do probando (antebraço), de seus familiares e de indivíduos normais, após concentimento informado, de acordo com VYSE et al. (1996), e funcionaram como fonte de ácidos nucléicos.

Os fragmentos de pele foram descontaminados em meio de cultura contendo excesso de penicilina $(500 \mathrm{U} / \mathrm{ml})$ e estreptomicina $(500 \mu \mathrm{g} / \mathrm{ml})$ por $2 \mathrm{~h}$. Cortes finos deste material foram colocados em garrafas de cultura contendo meio DMEM ( $\mathrm{pH}$ 7,2: meio de cultura comercial contendo HEPES a $25 \mathrm{mM}$, bicarbonato de sódio a $24 \mathrm{mM}$, L-glutamina a $2 \mathrm{mM} \mathrm{e}$ glicose a $25 \mathrm{mM}$, suplementado com de soro fetal bovino inativado (SFBi - 10\%), glutamina (1\%), penicilina $(50 \mathrm{U} / \mathrm{ml})$ e estreptomicina $(50 \mu \mathrm{g} / \mathrm{ml})$ e incubados a $37^{\circ} \mathrm{C}$. Após alguns dias de incubação, os fibroblastos atingiram $80 \%$ de confluência e, neste ponto, foram removidos com solução de tripsina ( $\mathrm{pH}$ 7,8: 0,08\% de tripsina, glicose a 5,5 mM, cloreto de sódio e EDTA a 0,5 mM em água Millli-Q), centrifugados e ressuspendidos novamente em meio 
DMEM suplementado (10\% SFBi) e semeados em novas garrafas. Por fim, quando as células estavam ocupando completamente o fundo da garrafa, elas foram estimuladas a produzir RNAm pela adição de $100 \mathrm{U}$ de INF/ml e incubadas por 24h. Após esse período, o RNA total dessas células foi, então, extraído (Reis et al., 2002; Ulbrich, 1999).

\subsection{Extração de RNA Total}

O RNA total foi extraído empregando-se o kit Total RNA Isolation System (Promega Corporation - Madson, WI, EUA), conforme PERRY et al (1972) e CHIRGWIN et al (1979), seguindo-se as instruções do fabricante. Para tal procedimento, aproximadamente $2 \times 10^{6}$ células foram lavadas em PBS e lisadas com solução de desnaturação [(fornecida pelo fabricante Promega: citrato de sódio $26 \mathrm{mM}(\mathrm{pH}$ 6,8), N-lauril sarcosina 0,5\%, $\beta$ mercaptoetanol 0,125 M e tiocianato de guanidina 4 M)]. Após a lise, o DNA e o RNA foram separados das proteínas por exposição ao NaOAc 2M e à solução de fenol:clorofórmio:álcool isoamílico (na proporção de 125:24:1). Após 15 min em gelo, o lisado foi centrifugado a $12.000 \mathrm{x} \mathrm{g}$ por $20 \mathrm{~min}$ a $4{ }^{\circ} \mathrm{C}$ e o sobrenadante transferido para um outro tubo, onde foi diluído a 1:1 em isopropanol. Esta solução foi, então, precipitada a $-20^{\circ} \mathrm{C}$, por $24 \mathrm{~h}$, para que o RNA pudesse ser separado dos demais componentes da solução. Após precipitação, nova centrifugação foi realizada a $12.000 \times \mathrm{x} \mathrm{a} 4{ }^{\circ} \mathrm{C}$ por 40 min e o sobrenadante desprezado. $\mathrm{O}$ precipitado, por sua vez, foi lavado com $1 \mathrm{ml}$ de EtOH 75\% gelado e ressuspendido em água autoclavada. 


\subsection{Quantificação do RNA}

O RNA total extraído foi quantificado por meio da absorbância a 260 e $280 \mathrm{~nm}$ em espectrofotômetro GeneQuant (GE), considerando-se 1 D.O. $=40 \mu \mathrm{g} / \mathrm{ml}$ de RNA. As amostras que apresentaram valor de 260/280 nm (grau de pureza) entre 1,7 e 2,0 foram empregadas.

4.11 “Reverse transcriptase-polymerase chain reaction” (RT-PCR) para Amplificação do cDNA de FH

As reações de RT-PCR foram realizadas empregando-se o kit "SuperScript One-Step RT-PCR System” (Invitrogen Life Technologies, Carlsbad, Califórnia), seguindo-se as instruções do fabricante. Foram utilizados oligonucleotídeos específicos (Quadro 1) para amplificação das porções desejadas do cDNA, conforme esquematizado na Figura 13. 
Quadro 1: Oligonucleotídeos utilizados em RT-PCR, PCR e seqüenciamento do cDNA de FH.

\begin{tabular}{ccc}
\hline & RT - PCR & \\
\hline Primer & Seqüência 5' $\rightarrow$ 3' & Sentido \\
\hline 1 & ATT TCT TGG AAG AGG AGA AC & F \\
753 & ATA AGG AGA ATG AAC GAT TTC & F \\
1483 & TTT TAA GGC ATA TGT ATA CGT & R \\
1560 & AAG ATG GAT GGT CAG CTC AAC & F \\
1662 & TCA TTC AGC TTA AAC CAT GTG & R \\
1969 & ACC TCC TGA ACT CCT CAA TG & F \\
2698 & CTG AGG TGG TTG TGA ACA TG & R \\
3167 & TGC ATT AAT AGC AGA TGG AC & F \\
3186 & GTC CAT CTG CTA TTA ATG CA & R \\
3919 & CCA CCG GTC TCA GCT TAT AA & R \\
\hline & PCR & \\
\hline FH GEN F & CAG TCC ATG CAC CAA GAA GGA & F \\
\hline FH GEN R & CAG GCT GCA TTC GTT TTT GGC & R \\
\hline
\end{tabular}

F: amplificação no sentido 5' - 3'; R: amplificação no sentido 3' - 5'. 


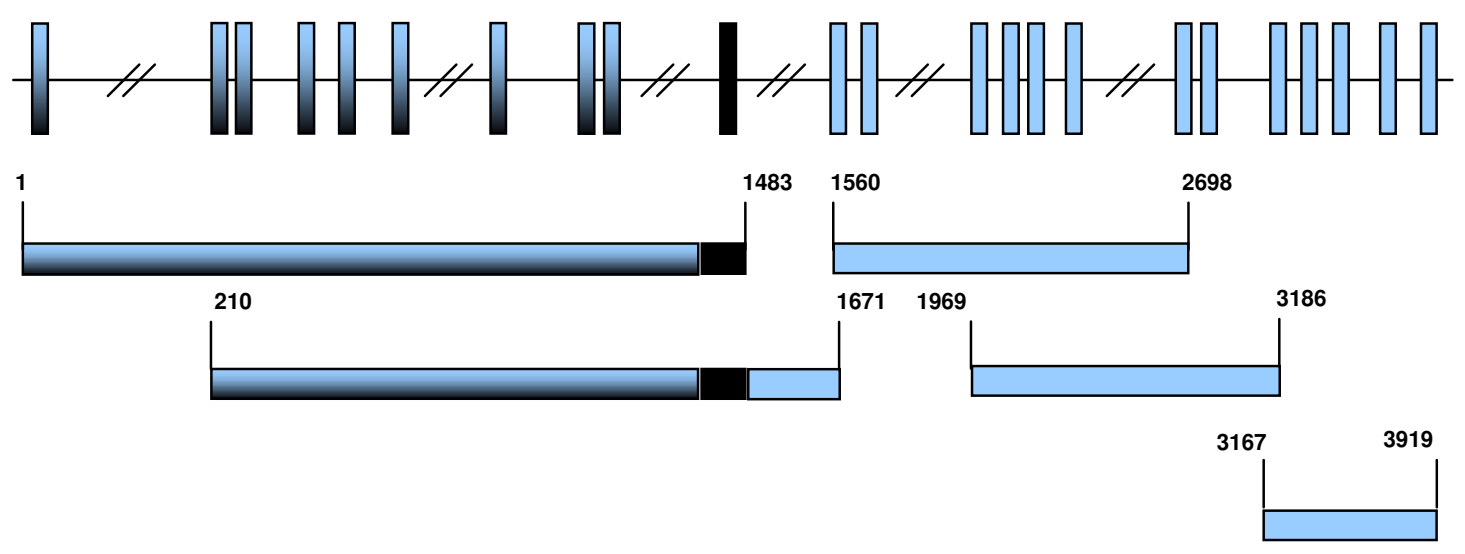

Figura 13: Representação esquemática dos fragmentos do cDNA de FH (3926 pb) amplificados e posteriormente seqüenciadas. Os números indicam o início e o fím de cada fragmento, compatíveis com os primers utilizados.

As reações foram preparadas para um volume final de $50 \mu \mathrm{L}$ contendo $100 \mathrm{ng}$ de RNA total, 20 pmoles de oligonucleotídeos, tampão (tampão contendo $0,4 \mathrm{mM}$ de cada dNTP e 2,4 $\mathrm{mM}$ de sulfato de magnésio - fornecido pelo fabricante) e $1 \mu \mathrm{L}$ de RT/Taq mix (mistura de Taq DNA polimerase recombinante com SuperScript ${ }^{\mathrm{TM}} \mathrm{H}$ transcriptase reversa). A primeira fita de cDNA correspondente ao RNAm poliadenilado foi produzida ao manter-se a reação a $50{ }^{\circ} \mathrm{C}$ por $30 \mathrm{~min}$. Em seguida, as moléculas de DNA foram desnaturadas a $94{ }^{\circ} \mathrm{C}$ por 2 min e os fragmentos específicos do cDNA amplificados após 40 ciclos na seguintes condições: $30 \mathrm{~s}$ a $94{ }^{\circ} \mathrm{C}, 30 \mathrm{~s}$ a $54{ }^{\circ} \mathrm{C}$ e $1 \mathrm{~min}$ a $72{ }^{\circ} \mathrm{C}$. Uma extensão final de 7 min a $72{ }^{\circ} \mathrm{C}$ foi realizada e os tubos mantidos a $4{ }^{\circ} \mathrm{C}$. A amplificação do cDNA do gliceraldeído 3-fosfato dehidrogenase (GAPDH) humano foi realizada como controle técnico das quantidades de RNA total empregadas nas reações.

Os produtos amplificados foram analisados após eletroforese em géis de agarose a $1 \%$ em tampão Tris-borato-EDTA submetidos a 8 V/cm durante 45-60 min. Após coloração com brometo de etídio, as bandas foram analisadas sob luz ultra-violeta e fotografadas. 


\subsection{PCR para Amplificação dos Éxons de C9}

As reações foram preparadas para um volume final de $25 \mu$ l quando foram adicionados de 1 a $2 \mu$ d do DNA genômico $(100 \mathrm{ng} / \mu \mathrm{L})$ do paciente ou de um controle normal, $2,5 \mu \mathrm{L}$ do tampão 10X (500 mM KCL, 15 mM MgCl2 e 100 mM Tris-HCL - GE Healthcare UK Limited, Buckinghamshire, UK), $10 \mathrm{mM}$ de dNTPs, os oligonucleotídeos específicos (50 ng/ $\mu \mathrm{L}$ ) (Quadro 2), $5 \mathrm{U}$ de $r$ Taq DNA polymerase (GE Healthcare UK Limited, Buckinghamshire, UK) e água q.s.p. para $25 \mu \mathrm{L}$. A reação de amplificação propriamente dita foi feita a $95{ }^{\circ} \mathrm{C}$ por 1 min seguida por 40 ciclos de: 1 min s a $95{ }^{\circ} \mathrm{C}, 1$ min a $54-62{ }^{\circ} \mathrm{C}$ (dependendo dos oligonucleotídeos utilizados) e 1 min de extensão a $72{ }^{\circ} \mathrm{C}$. Ao final dos ciclos, foi realizada uma extensão final a $72{ }^{\circ} \mathrm{C}$ por 7 min e os tubos foram mantidos a $4{ }^{\circ} \mathrm{C}$. Os produtos amplificados foram analisados após eletroforese em géis de agarose a $1 \%$ em tampão Tris-borato-EDTA (TBE - $100 \mathrm{mM}$ de Tris, $100 \mathrm{mM}$ de ácido bórico e $2 \mathrm{mM}$ de EDTA) submetidos a $8 \mathrm{~V} / \mathrm{cm}$ durante 45-60 min. Após coloração com brometo de etídio, as bandas foram analisadas sob luz ultra-violeta e fotografadas. 
Quadro 2: Oligonucleotídeos utilizados em PCR e seqüenciamento das regiões de C9 a partir de DNA genômico.

\begin{tabular}{|c|c|c|}
\hline \multicolumn{3}{|c|}{ PCR } \\
\hline Primer & Seqüência 5' $\rightarrow$ 3' & Sentido \\
\hline $1 \mathrm{~F}$ & ATT CTC CTT TGG TTG GAC TTC & $\mathrm{F}$ \\
\hline $1 \mathrm{R}$ & CAT TGT CAT GTA CTT TGC TGC & $\mathrm{R}$ \\
\hline $2 \mathrm{~F}$ & GAC TTC TTG GAA ACA GAT ATA C & $\mathrm{F}$ \\
\hline $2 \mathrm{R}$ & GGC TCC CTG CCT CAT AAT CAT & $\mathrm{R}$ \\
\hline $3 \mathrm{~F}$ & AAC CAT TGA CTG ATT GCA GGG & $\mathrm{F}$ \\
\hline $3 \mathrm{R}$ & TTC ATT CAG GAA GGC ACA CAG & $\mathrm{R}$ \\
\hline $4 \mathrm{~F}$ & GAT ACC TCA CCT CCA GGG TTA & $\mathrm{F}$ \\
\hline $4 \mathrm{R}$ & CAC CTA TGT CCC TCG CAC AAA & $\mathrm{R}$ \\
\hline $5 \mathrm{~F}$ & GTT GTG GTA TTT CCA CTT CTG & $\mathrm{F}$ \\
\hline $5 \mathrm{R}$ & TCC AAA CTA CAT CGC CTC TTC & $\mathrm{R}$ \\
\hline $6 \mathrm{~F}$ & TTG CTC TTA ACT CCT TTG TTC & $\mathrm{F}$ \\
\hline $6 \mathrm{R}$ & TGG GTA GTT TGG AAC CTT TC & $\mathrm{R}$ \\
\hline $7 \mathrm{~F}$ & GGT ATC TCA TGG TCA CTG CTA & $\mathrm{F}$ \\
\hline $7 \mathrm{R}$ & GCA GGT TAC AGG GCT TTG TAT & $\mathrm{R}$ \\
\hline $8 \mathrm{~F}$ & CAG GAC AGA CAT GAT GGC ACA & $\mathrm{F}$ \\
\hline $8 \mathrm{R}$ & CAT TGA CAT CTA CCC TCA GGC & $\mathrm{R}$ \\
\hline $9 \mathrm{~F}$ & CTT TTG ATA ACT GGC TTC TC & $\mathrm{F}$ \\
\hline $9 \mathrm{R}$ & AAT GAC ACA GTC TTC TGT TTG & $\mathrm{R}$ \\
\hline $10 \mathrm{~F}$ & GTA TTC TAC AAG TTC TCT CAG & $\mathrm{F}$ \\
\hline $10 \mathrm{R}$ & AAT TAG ATA ACC CCA AAG TGC & $\mathrm{R}$ \\
\hline $11 \mathrm{~A} \mathrm{~F}$ & GGA CCC AAA GTA AAA TCC TAT TG & $\mathrm{F}$ \\
\hline $11 \mathrm{~A} \mathrm{R}$ & CTG AAT GAA TGT ATG CAC ACC & $\mathrm{R}$ \\
\hline $11 \mathrm{~B} \mathrm{~F}$ & GTA TGG TTA ACA TAT TCT GCC & $\mathrm{F}$ \\
\hline 11B R & TAA GCA CCA TGT TCT CTA ATG & $\mathrm{R}$ \\
\hline
\end{tabular}




\subsection{Purificação do DNA a Partir do Gel de Agarose}

Os fragmentos de cDNA amplificados foram aplicados em gel de agarose $1 \%$ sob tampão TBE. Após a coloração em brometo de etídio, a área contendo o cDNA foi cortada do gel e utilizou-se o kit "Concert ${ }^{T M}$ Gel Extraction Systems" (GIBCO Invitrogen Incorporation, Carlsbad, Califórnia), segundo Vogelstein \& Gillespie (1979), para a extração. A área contendo o cDNA foi colocada em um tubo, onde foi adicionado o tampão de solubilização (perclorato de sódio, acetato de sódio e TBE, fornecido pelo fabricante), com posterior incubação de $15 \min$ a $50{ }^{\circ} \mathrm{C}$.

Transferiu-se o material solubilizado para uma coluna de filtração e centrifugou-se a $12.000 \times g$ por 1 min. Descartou-se o eluato e adicionou-se à coluna mais $500 \mu \mathrm{L}$ de tampão de lavagem ( $\mathrm{NaCl}$, EDTA, Tris-HCL e EtOH, fornecido pelo fabricante), com nova centrifugação. Por fim, o cDNA foi eluído em $50 \mu \mathrm{L}$ de tampão TE $(10$ mM Tris-HCl e 0,1 mM de EDTA).

\subsection{Extração de DNA Genômico Utilizando DNAzol}

As células da garrafa de cultura foram removidas usando tripsina $(0,1 \%$ de tripsina e $1 \mathrm{mM}$ de EDTA) ( 2x10 céls.) por aproximadamente 3 min a $37^{\circ} \mathrm{C}$. Adicionou-se $0,5 \mathrm{ml} \mathrm{de}$ DNAzol (Invitrogen Life Technologies, Carlsbad, Califórnia) às células, homogeinizando com a pipeta para auxiliar a lise. Adicionou-se, então, 0,3 ml de EtOH 100\% e centrifugou-se a 1.000 x $g$ por $10 \mathrm{~min}$. Retirou-se o sobrenadante e lavou-se o precipitado com $1 \mathrm{ml}$ de etanol 95\%. Esperou-se o precipitado secar, com o tubo aberto à temperatura ambiente, dissolvendoo em $200 \mu \mathrm{L}$ de TE. 


\subsection{Reações de Seqüenciamento}

Em um volume final de $20 \mu \mathrm{L}$ de reação, adicionamos: 300 ng de DNA/cDNA, $1 \mu \mathrm{L}$ de oligonucleotídeos específicos $(3,2$ pmols/ $\mu \mathrm{L}), 6 \mu \mathrm{L}$ de tampão (200 mM tris-HCL e $5 \mathrm{mM}$ $\mathrm{MgCL}_{2} \mathrm{pH}$ 9,0), $2 \mu \mathrm{L}$ de enzima mix (fornecido pelo fabricante GE Healthcare UK Limited, Buckinghamshire, UK) e água suficiente para completar $20 \mu \mathrm{L}$. Esta mistura foi colocada para reagir a $96{ }^{\circ} \mathrm{C}$ por $10 \mathrm{~s}$ (desnaturação), a $50{ }^{\circ} \mathrm{C}$ por $5 \mathrm{~s}$ (anelamento) e a $60{ }^{\circ} \mathrm{C}$ por 4 min (amplificação propriamente dita). Estas etapas repetiram-se seguidamente por 40 vezes. Terminados os ciclos, $80 \mu \mathrm{L}$ de isopropanol $75 \%$ foram adicionados e deixando-se reagir por 15 min à temperatura ambiente. Terminado este tempo, centrifugou-se o material por 20 min e lavou-se o precipitado com $250 \mu \mathrm{L}$ de isopropanol $75 \%$, seguida de nova centrifugação por 5 minutos. As reações, uma vez preparadas em nosso laboratório, foram seqüenciadas no Departamento de Bioquímica, Instituto de Química, Universidade de São Paulo, quando contamos com a colaboração do Prof. Dr. Shaker Chuck Farah.

\subsection{Microscopia Confocal}

A metodologia empregada neste experimento foi adaptada a partir da publicada por Fishelson et al (1999).

Fibroblastos foram cultivados sobre lamínulas por 24h em meio de cultura DMEM completo e em seguida estimulados por $20 \mathrm{~h}$ com LPS $1 \mu \mathrm{g} / \mathrm{ml}$. Após este período, as células foram lavadas com PBS (fosfato de potássio dibásico a $5 \mathrm{mM}$, fosfato de potássio monobásico a 1,2 mM e cloreto de sódio a $150 \mathrm{mM}$ - pH 7,2) e fixadas com 3,7\% formaldeído em PBS por 15 min. Logo após, as células foram lavadas com glicina 0,1M em PBS (PBS-glicina) e depois apenas com PBS. As células foram, então, permeabilizadas com 0,2\% Triton X-100 em PBS por 2 min, lavadas 2X com PBS contendo 10\% soro bovino fetal inativado (PBS- 
SBFi) e incubadas por 10 min com PBS-SBFi. O tampão foi aspirado e as células incubadas a $4^{\circ} \mathrm{C}$ com anticorpo anti-FH humano feito em cabra diluído 1:200 em PBS-glicina, por pelo menos 16h. Em seguida, as células foram lavadas 3X com PBS-SBFi e incubadas à temperatura ambiente com soro normal de coelho diluído 1:200 em PBS-SBFi, por $30 \mathrm{~min}$. O material foi, então, lavado 5X com PBS-SBFi e incubado com anticorpo de coelho anti-IgG de cabra marcado com FITC, por 1h à temperatura ambiente no escuro. Após novo ciclo de lavagens com PBS-SBFi (5X) foi feita nova incubação com RNAse 10mg/ml em PBS por 30 min à temperatura ambiente no escuro. Finalmente, o material foi novamente lavado com PBS-SBFi (3X), incubado com iodeto de propídeo $10 \mathrm{mg} / \mathrm{ml}$ por $30 \mathrm{~min}$ à temperatura ambiente no escuro e as lâminas montadas com Gel Mount (Vectashield). As análises foram feitas no dia seguinte à montagem, em microscópio confocal. 


\section{V_RESULTADOS}

5.1 Determinação das Atividades Hemolíticas das Vias Clássica e Alternativa no Soro do Paciente e de Seus Familiares

Uma vez que deficiências de proteínas do C estão diretamente associadas com o comprometimento funcional desse sistema, optamos por avaliar essa funcionalidade através do poder que as proteínas componentes das vias clássica e alternativa, presentes no soro do paciente e de seus familiares, teriam para provocar a lise de hemácias não próprias.

Foram feitos dois tipos de ensaio hemolítico para avaliar a ativação das vias clássica e alternativa nos soros do paciente e de seus familiares.

O soro do paciente não apresentou evidências de atividade hemolítica por qualquer das vias (Tabela 9), indicando a possibilidade da presença em baixas concentrações de uma proteína do $\mathrm{C}$ comum às duas vias, como é o caso do $\mathrm{C} 3$ e/ou dos componentes da via terminal. A queda na concentração de C3 pode acontecer como resultado de um processo infeccioso, que leva a um consumo elevado desta proteína, de uma alteração genética que leve a problemas de produção ou secreção de C3 no soro do paciente (deficiência primária) ou da deficiência de proteínas reguladoras do C, que, uma vez ausentes, não impediriam o consumo excessivo de C3 quando da ativação do C (deficiência secundária). Uma vez que o paciente apresentava-se assintomático no momento da coleta de soro, restaram apenas as possibilidades de deficiências primárias e secundárias de C3 a serem investigadas, bem como a deficiência de componentes da via terminal do C. 
Tabela 9: Porcentagem das Atividades Hemolíticas Dependentes das Vias Clássica e Alternativa nos Soros do Paciente e de Sua Família.

\begin{tabular}{|l|c|c|}
\hline \multirow{2}{*}{} & \multicolumn{2}{|c|}{ Atividade Hemolítica } \\
\cline { 2 - 3 } & Via Alternativa (\%) & Via Clássica (\%) \\
\hline Paciente & Sem lise & Sem lise \\
\hline Pai & 117,47 & 127,59 \\
\hline Mãe & 43,28 & 75,72 \\
\hline Irmã & 82,2 & 119,67 \\
\hline Normal & $71-171$ & $56-192$ \\
\hline
\end{tabular}

O soro da mãe foi capaz de provocar hemólise em níveis normais pela via clássica $(75,7 \%)$, mas não pela via alternativa $(43,3 \%)$. Este resultado indica uma provável deficiência de proteínas da via alternativa do C também no soro da mãe. Diante das possibilidades citadas acima e uma vez que o soro da mãe foi menos capaz de provocar hemólise pela via alternativa, sinais da existência da deficiência de proteínas do C pertencentes à via alternativa, mas não às vias clássica e terminal tornaram-se evidentes.

Os soros do pai e irmã foram capazes de mediar hemólise em níveis normais, tanto pela via clássica $(127,6 \%$ e $119,7 \%$, respectivamente) quanto pela via alternativa $(117,5 \%$, $82,2 \%$, respectivamente). Estes dados indicam a presença de níveis próximos do normal ou mesmo níveis normais das proteínas do $\mathrm{C}$ nos soros do pai e irmã do paciente, habilitando-os a mediarem hemólise pelas duas vias avaliadas. 
5.2 Determinação da Concentração das Proteínas do Complemento no Soro do Paciente e de sua Família

Indivíduos deficientes de C3 de forma primária ou secundária apresentam atividade hemolítica inexistente ou reduzida, tanto pela via clássica (e via das lectinas) como pela alternativa, por ser este um componente central para a ativação das três vias do C. Assim, decidimos avaliar a sua concentração no soro do paciente e de seus familiares, bem como de outras proteínas também envolvidas na via alternativa, como FB, de reguladores que atuam ao nível de C3, como FH e FI, de C4, componente da via clássica, e de properdina, proteína envolvida na via terminal.

Sabendo que algumas proteínas do C encontram-se normalmente em concentrações séricas elevadas, como é o caso do C3 (em torno de $1.300 \mu \mathrm{g} / \mathrm{ml}$ ) e do FH (em torno de 600 $\mu \mathrm{g} / \mathrm{ml}$ ), optamos inicialmente por um método menos sensível e cuja sensibilidade limita-se à detecção de proteínas presentes na amostra a partir da escala de microgramas, como é o caso da Imunodifusão Radial (Mancini). Uma vez que o FH foi encontrado em concentrações muito baixas (abaixo do limite de detecção do método) (resultado não mostrado) no soro do paciente em diferentes ensaios, decidimos, então, substituir a imunodifusão radial por um método mais sensível na detecção da concentração desta proteína, o ELISA, cujo limite de detecção permite a identificação de proteínas presentes na amostra desde a escala de picogramas.

Assim, para determinar a concentração de C3, C4, FB e FI nós utilizamos o método de imunodifusão radial, enquanto que a concentração do FH no soro do paciente e de seus familiares foi avaliada pelo método de ELISA sanduíche.

Avaliamos, ainda, a concentração de properdina pela utilização de kit de imunodifusão radial (The Binding Site) de acordo com as instruções fornecidas pelo fabricante. 
5.2.1 Determinação da Concentração de C3, C4, FB, FI e properdina no Soro do Paciente e de sua Família Utilizando o método de Imunodifusão Dupla

Usando imunodifusão radial (Mancini et al, 1965) nós determinamos a concentração de C3, C4, FB, FI e properdina no soro do paciente e de seus familiares (Tabela 10). Os valores normais usados para comparação foram estabelecidos por Ferriani et al, 1999 e Ferreira de Paula et al, 2003.

Tabela 10: Concentração de C3, C4, FB, FI e properdina no soro do paciente e de su família.

\begin{tabular}{|c|c|c|c|c|c|}
\hline & $\begin{array}{c}\mathrm{C3} \\
\mu \mathrm{g} / \mathrm{mL} \\
\end{array}$ & $\begin{array}{c}\mathrm{C} 4 \\
\mu \mathrm{g} / \mathrm{mL} \\
\end{array}$ & $\begin{array}{c}\text { FB } \\
\mu \mathrm{g} / \mathrm{mL}\end{array}$ & $\begin{array}{c}\text { FI } \\
\mu \mathrm{g} / \mathrm{mL}\end{array}$ & $\begin{array}{c}\text { Properdina } \\
\mu \mathrm{g} / \mathrm{mL}\end{array}$ \\
\hline Paciente & $<<$ & 467,7 & $<<$ & 51,6 & 12 \\
\hline Pai & 1271 & 807,3 & 105,9 & 52,2 & $\mathrm{Nd}$ \\
\hline Mãe & 382,6 & 514,4 & 62,45 & 23,6 & $\mathrm{Nd}$ \\
\hline Irmã & 1271,1 & 615,5 & $\mathrm{Nd}$ & $\mathrm{Nd}$ & $\mathrm{Nd}$ \\
\hline $\begin{array}{l}\text { Normal }\left(3-4 \text { anos }^{\mathrm{a}} ; 1-6 \operatorname{anos}^{\mathrm{b}}\right) \text { : } \\
\text { média }\end{array}$ & $905^{\mathrm{a}}$ & $16,4^{\mathrm{a}}$ & - & $57,9^{\mathrm{b}}$ & $23,1^{\mathrm{b}}$ \\
\hline $\begin{array}{l}\text { Normal }\left(3-4 \operatorname{anos}^{\mathrm{a}} ; 1-6 \operatorname{anos}^{\mathrm{b}}\right) \text { : } \\
\text { intervalo }\end{array}$ & $610-1410^{\mathrm{a}}$ & $95-302^{\mathrm{a}}$ & - & $29,97-103,54^{\mathrm{b}}$ & $13,22-38,01^{\mathrm{b}}$ \\
\hline Normal (adulto): média & - & - & $180^{\mathrm{d}}$ & $63,9^{\mathrm{b}}$ & $26,48^{\mathrm{b}}$ \\
\hline Normal (adulto): intervalo & $800-1900^{c}$ & $450-600^{\mathrm{a}}$ & $74-286^{\mathrm{d}}$ & $38,78-100,49^{\mathrm{b}}$ & $14,53-40,61^{b}$ \\
\hline & & & & & \\
\hline
\end{tabular}

Como esperado, o paciente apresentou níveis muito baixos de C3 (abaixo do limite de detecção do método) e surpreendentemente elevados de C4 (467,7 $\mu \mathrm{g} / \mathrm{ml})$. Entretanto, observamos que o paciente apresentava, além dos níveis muito reduzidos de C3, níveis 
também muito reduzidos de FB (abaixo do limite de detecção do método) e níveis reduzidos, porém dentro da faixa de normalidade, da proteína reguladora FI $(51,6 \mu \mathrm{g} / \mathrm{ml})$.

Sabendo que pacientes deficientes de proteínas que regulam a ativação C podem ter consumo excessivo de outras proteínas envolvidas na sua ativação, como o C3 e FB, em virtude da ativação desregulada, este último achado levou-nos a suspeitar que a deficiência de C3 do paciente em questão seria secundária à deficiência primária de uma proteína reguladora. Como as proteínas excessivamente consumidas pertenciam à via alternativa e sabendo que a concentração do componente $\mathrm{C} 4$, pertencente à via clássica, encontrava-se em concentrações elevadas, pudemos, então sugerir que a proteína reguladora ausente no soro do paciente seria possivelmente responsável pela regulação da via alternativa. Uma vez que os principais reguladores da via alternativa são o FI e seu co-fator, o FH, e sabendo que a concentração de FI no soro do paciente, apesar de reduzida, encontrava-se dentro da faixa de normalidade, pudemos então propor que o paciente em questão era deficiente primário da proteína reguladora $\mathrm{FH}$.

Avaliamos, ainda, a concentração de properdina no soro do paciente, e encontramos concentrações levemente reduzidas $(12 \mu \mathrm{g} / \mathrm{ml})$ desse regulador, entretanto, com valor muito próximo ao do limite inferior da faixa de normalidade.

O soro da mãe do paciente apresentou níveis normais de C4 $(514,4 \mu \mathrm{g} / \mathrm{ml})$, mas muito reduzidos de C3 $(382,6 \mu \mathrm{g} / \mathrm{ml})$ e FB $(62,45 \mu \mathrm{g} / \mathrm{ml})$. Este resultado indica que a concentração de FH no soro da mãe está possivelmente também muito reduzida, a ponto de também ser insuficiente para evitar o consumo excessivo de C3 e FB. Da mesma forma que no paciente, a concentração de FI no soro apresentou níveis reduzidos, 23,6 $\mu \mathrm{g} / \mathrm{ml}$.

O soro do pai, por sua vez, apresentou concentrações normais de C3 (1270,7 $\mu \mathrm{g} / \mathrm{ml})$ e FB $(105,9 \mu \mathrm{g} / \mathrm{ml})$. Os níveis de FI $(52,2 \mu \mathrm{g} / \mathrm{ml})$ estavam levemente reduzidas, entretanto 
dentro da faixa de normalidade considerada, enquanto os de $\mathrm{C} 4(807,6 \mu \mathrm{g} / \mathrm{ml})$ estavam surpreendentemente muito elevados.

Da mesma forma que o soro do pai, o soro da irmã apresentou concentrações normais de C3 $(1271,1 \mu \mathrm{g} / \mathrm{ml})$ e muito elevadas de C4 $(615,5 \mu \mathrm{g} / \mathrm{ml})$.

5.2.2 Determinação da Concentração de FH no Soro do Paciente e de sua Família Utilizando o método ELISA

Tendo proposto que o paciente estudado seria deficiente primário da proteína reguladora $\mathrm{FH}$, decidimos avaliar sua concentração no soro do paciente e de seus familiares pelo método ELISA.

A concentração de FH encontrada no soro do paciente foi de $16,8 \mu \mathrm{g} / \mathrm{ml}$ (Tabela 11). Este valor representa menos de 5\% da concentração encontrada em indivíduos normais, enquadrando o nosso paciente entre os deficientes totais desta proteína. Este resultado é compatível com os encontrados para a atividade hemolítica do soro do paciente, e com as concentrações de C3 e FB detectadas na etapa anterior, uma vez que a ausência desta proteína reguladora levaria ao consumo excessivo de $\mathrm{C} 3 \mathrm{e}$, conseqüentemente à incapacidade ativar o C por qualquer três das vias. 
Tabela 11: Concentração de FH nos Soros do Paciente e de Sua Família

\begin{tabular}{|l|c|}
\hline \multicolumn{1}{|c|}{ Indivíduo } & FH $(\boldsymbol{\mu g} / \mathbf{m L})$ \\
\hline Paciente & 16,8 \\
\hline Pai & 190,9 \\
\hline Mãe & 140,5 \\
\hline Irmã & 143,6 \\
\hline $\begin{array}{l}\text { Normal (1-6 anos): } \\
\text { média }\end{array}$ & $606,1^{\mathrm{a}}$ \\
\hline $\begin{array}{l}\text { Normal (1-6 anos): } \\
\text { intervalo }\end{array}$ & $233,46-1319,49^{\mathrm{a}}$ \\
\hline $\begin{array}{l}\text { Normal (Adultos): } \\
\text { média }\end{array}$ & $442,7^{\mathrm{a}}$ \\
\hline $\begin{array}{l}\text { Normal (Adultos): } \\
\text { intervalo }\end{array}$ & $241,8-758,91^{\mathrm{a}}$ \\
\hline
\end{tabular}

A concentração de FH encontrada no soro da mãe $(140,5 \mu \mathrm{g} / \mathrm{ml})$ representa $31,7 \%$ da concentração encontrada em indivíduos normais.

Nos soros do pai e irmã do paciente o FH foi encontrado nas seguintes concentrações: 190,9 $\mu \mathrm{g} / \mathrm{ml}$ e 143,6 $\mu \mathrm{g} / \mathrm{ml}$, respectivamente. Estes valores representam 43,1\% e 23,7\%, respectivamente, da concentração encontrada em indivíduos normais e são compatíveis com uma deficiência parcial desta proteína. Estes dados também estão em acordo com a atividade hemolítica exibida por esses soros, uma vez que esses níveis de FH garantem a presença deste regulador em concentração suficiente para evitar o consumo excessivo de C3, quando da ativação do $\mathrm{C}$ e a capacidade de induzir hemólise a níveis normais. 
5.3 Avaliação do Perfil das Proteínas da Família FH no Soro do Paciente e de Seus Familiares Utilizando o Western Blot.

De posse de todos os dados corroborando com a proposição do paciente estudado ser portador de deficiência de $\mathrm{FH}$, e diante da possibilidade de alterações funcionais do $\mathrm{FH}$ encontrado no soro da mãe, tornou-se indispensável a utilização de um método que possibilitasse a avaliação do perfil eletroforético desta proteína e que, conseqüentemente, nos fornecesse algumas informações estruturais do FH presente no soro do paciente e de sua família. Por esta razão, procedemos com a análise do FH no soro desta família por Western Blot.

Adicionalmente, o conhecimento da existência de proteínas antigenicamente relacionadas ao FH (família $\mathrm{FH}$ ), contudo sem atividade de regulação da ativação do $\mathrm{C}$ completamente esclarecida e que estas poderiam ser as responsáveis pela concentração residual de FH detectada no soro do paciente e de sua mãe, tornou-se, então, necessário avaliar quais membros da família FH estariam presentes no soro do paciente e de seus familiares também pelo Western Blot; uma vez que os anticorpos utilizados nos métodos de imunodifusão radial e ELISA não eram capazes de fazer tal distinção. Nossos resultados mostram o perfil das proteínas da família FH presentes no soro do paciente e de sua família em comparação com o controle normal (Figura 14). 


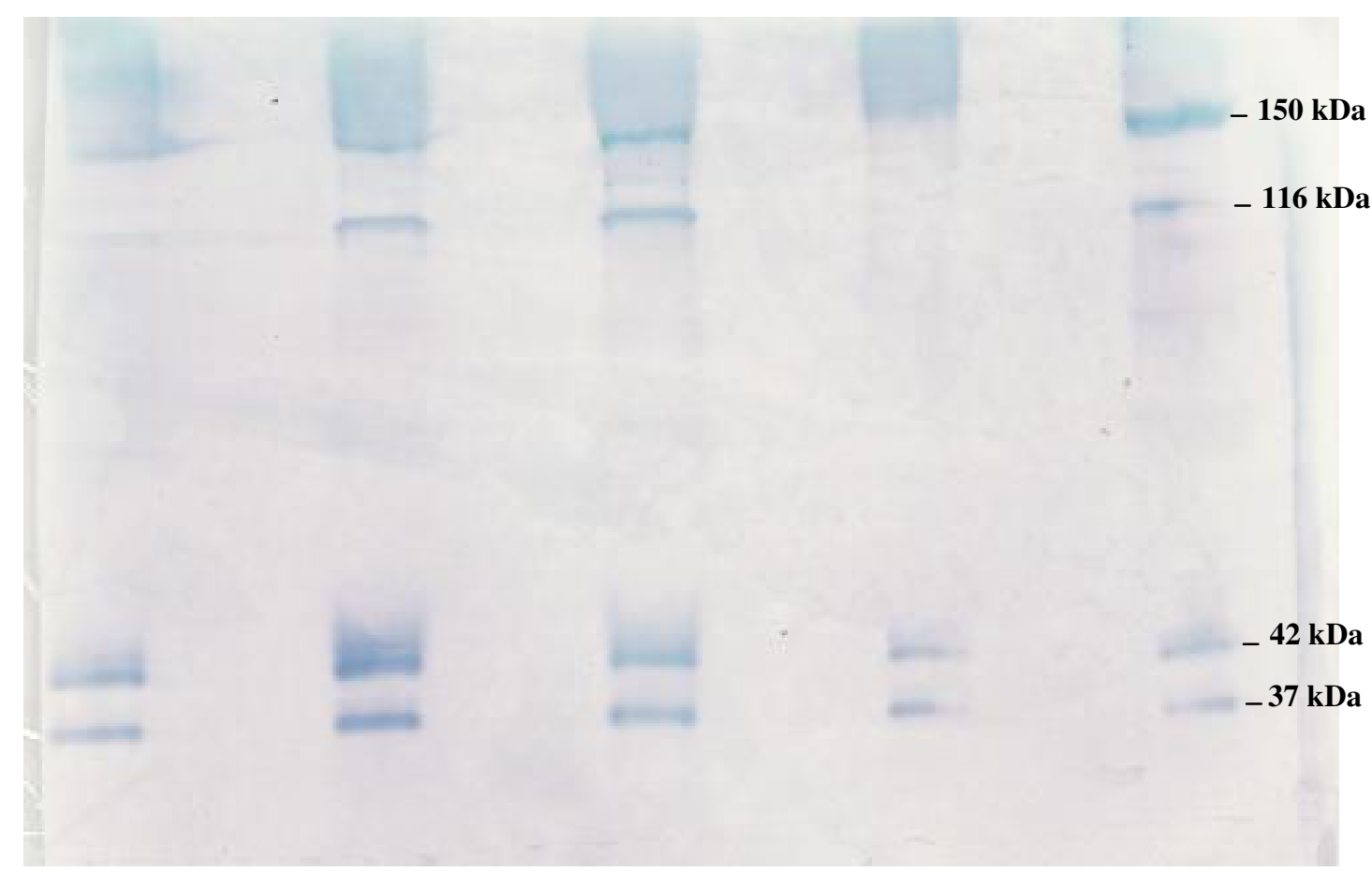

Figura 14: Análise do perfil do $\mathrm{FH}$, e das proteínas antigenicamente relacionadas a ele, presentes no soro do paciente e de sua família através de Western Blotting usando anticorpo policlonal de cabra anti-FH humano (gentilmente cedido pela Dra. Pilar Sánchez-Corral, Espanha) como anticorpo primário.

O FH (150 kDa) estava completamente ausente no soro do paciente, mas presente no soro de seus pais e irmã, resultado que confirma o enquadramento do paciente entre os deficientes totais desta proteína. Apesar disso, o resultado mostrou a presença no soro do paciente de outras proteínas, com aproximadamente $37 \mathrm{kDa}$, peso molecular equivalente ao do FHR-1 $\alpha, 42$ kDa, peso correspondente ao do FHL-1 e do FHR-1 $\beta$ e 116 kDa, de identidade por nós desconhecida. Vale ressaltar que esta proteína de 116 kDa estava presente em concentração aparentemente muito reduzida quando comparada à encontrada no soro controle. 
Pudemos observar também que no soro da mãe do paciente o FH (150 kDa) estava presente em concentração aparentemente baixa, quando comparadas com o controle normal, entretanto mais elevadas que as detectadas no paciente, resultado que está de acordo com os obtidos pelo método ELISA. Entretanto, vale destacar que as proteínas de $37 \mathrm{kDa}$ e $42 \mathrm{kDa}$ estavam presentes em concentrações possivelmente mais elevadas que as encontradas no paciente e no controle normal. Este resultado leva-nos a vislumbrar a possibilidade de que a concentração aumentada de FH detectada no soro da mãe pelo método ELISA, em comparação com a detectada no soro do paciente, possa sofrer influência parcial da concentração mais elevada dessas duas proteínas. A proteína de 116 kDa também estava presente no soro da mãe.

Finalmente, observamos nos soros do pai e irmã do paciente, a presença tanto da proteína reguladora $(\mathrm{FH})$, como também de outros membros de sua família de proteínas, FHL1, FHR-1 $\alpha$, FHR-1 $\beta$, além da proteína de aproximadamente $116 \mathrm{kDa}$. Até o momento não temos conhecimento de qualquer proteína da família de proteínas do FH com tamanho equivalente ao desta proteína, não sendo possível, portanto, determinar a sua identidade.

Vale ressaltar que todas as proteínas detectadas neste ensaio tiveram perfil eletroforético semelhante ao das detectadas tanto no soro do controle como na amostra de proteínas purificadas, indicando a ausência de alterações estruturais grosseiras nas respectivas proteínas.

Como comentado previamente, tínhamos conhecimento de uma limitação técnica presente no ensaio anterior, já que o anticorpo usado não possibilitava a distinção antigênica entre alguns membros da família FH, FHL-1 e FHR-1 $\beta$, com peso molecular muito semelhante. Sabendo que uma alteração molecular no gene $F H$ que cause a deficiência de FH num indivíduo pode causar também a deficiência de FHL-1, uma vez que são codificadas pelo 
mesmo gene, foi usado um outro anticorpo policlonal feito em coelho capaz de reagir apenas com os SCRs-1 a -4 (anti-SCR1-4) humanos (gentilmente cedido pelo Dr. Peter Zipfel, Alemanha), e, portanto, capaz de detectar somente as proteínas de $150 \mathrm{kDa}(\mathrm{FH})$ e $42 \mathrm{kDa}$ (FHL-1), por serem as únicas proteínas da família FH a possuírem tais SCRs em sua estrutura (Figura 15).

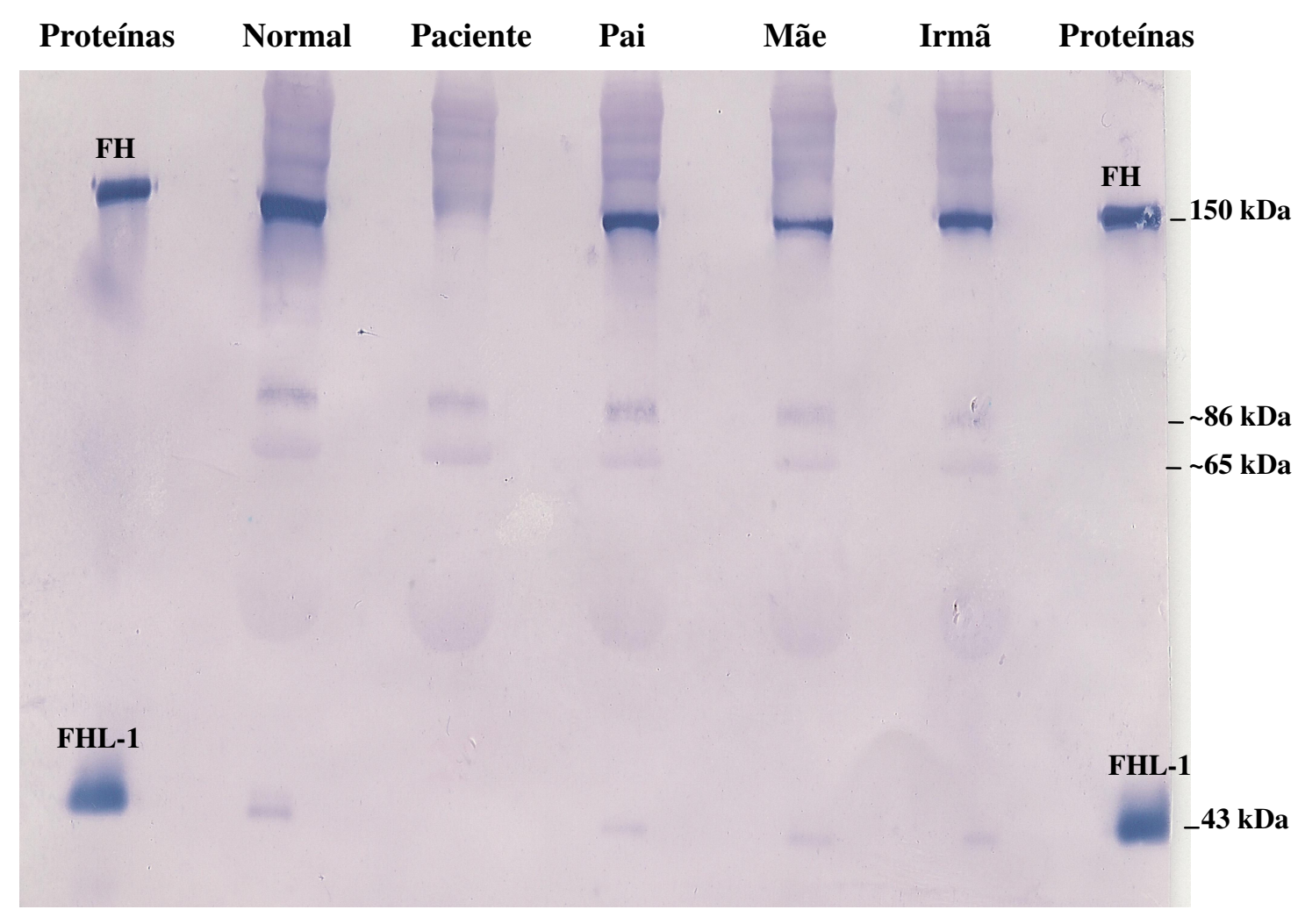

Figura 15: Análise do perfil do FH e do FHL-1 presentes no soro do paciente e de sua família através de Western Blotting utilizando anticorpo policlonal de coelho anti-SCR(1-4) humano (gentilmente cedido pelo Dr. Peter Zipfel, Alemanha) como anticorpo primário.

A proteína FHL-1 de $42 \mathrm{kDa}$ estava também completamente ausente no soro do paciente, mas presente nos soros de seus familiares. Este resultado nos leva a sugerir que, uma vez que esta proteína e o FH são codificados pelo mesmo gene e sabendo que as duas proteínas estão ausentes no soro do paciente, a alteração molecular responsável pela ausência do FH no soro do paciente está possivelmente localizada nos primeiros sete SCRs desta 
proteína, já que são os SCRs compartilhados exclusivamente pelo FH e pelo FHL-1, ou afeta a expressão de ambas as proteínas.

Detectamos, ainda, duas outras proteínas, presentes em todos os soros examinados, com pesos moleculares aproximados entre $86 \mathrm{kDa}$ e $65 \mathrm{kDa}$. Sabemos que os pesos moleculares do FHR-4 e do FHR-5 são de aproximadamente de 86 kDa e 65 kDa, respectivamente. Entretanto, o anticorpo usado no ensaio detecta apenas os primeiros quatro SCRs do FH e estes não são compartilhados pelos FHRs da família FH. Assim, torna-se pouco provável que a identidade dessas duas proteínas detectadas neste ensaio possa ser atribuída a essas duas proteínas. Como, até o momento, não temos conhecimento de outros membros da família FH que tenham pesos moleculares semelhantes aos dessas proteínas detectadas neste ensaio, não pudemos identificá-las e determinar sua identidade. A Tabela 12 apresenta um resumo das proteínas da família FH encontradas no soro do paciente e de seus familiares.

Tabela 12: Proteínas da família FH encontradas nos soros do paciente e de seus familiares.

\begin{tabular}{|l|c|c|c|c|}
\hline & \multicolumn{4}{|c|}{ Proteínas } \\
\hline Indivíduo & FH & FHL-1 & FHR-1 $\alpha$ & FHR-1 $\beta$ \\
\hline Paciente & - & - & + & + \\
\hline Pai & + & + & + & + \\
\hline Mãe & + & + & + & + \\
\hline Irmã & + & + & + & + \\
\hline
\end{tabular}


A esta altura do projeto, já tínhamos ciência de que o paciente estudado era portador da deficiência de FH e de FHL-1, e que outras proteínas do C haviam sido afetadas secundariamente por esta deficiência primária, estando também ausentes ou presentes em baixas concentrações no soro do paciente, como C3 e FB. Assim, como passo seguinte, optamos por fazer uma triagem semi-quantitativa das proteínas pertencentes à via terminal, pelo método de imunodifusão dupla, a fim de nos certificar de que outras proteínas não estariam de alguma forma afetando a funcionalidade do C.

5.4 Imunodifusão Dupla Para Detecção das Proteínas da Via Terminal: C6, C6, C7, C8 e C9.

Através de ensaios de imudifusão dupla (Ouchterlony \& Nilsson, 1978) nós avaliamos semi-quantitativamente a presença das proteínas da via terminal do C, C5, C6, C7, C8 e C9 no soro do paciente e de seus familiares.

As primeiras quatro proteínas (C5, C6, C7 e C8) estavam presentes nos soros do paciente e de seus familiares, mesmo quando diluídos até 1: 32 (resultado não mostrado). Já o componente C9 (Figura 16), estava presente nos soros de seus pais e irmã, mas ausente no soro do paciente mesmo quando testado na forma pura (não diluída). 


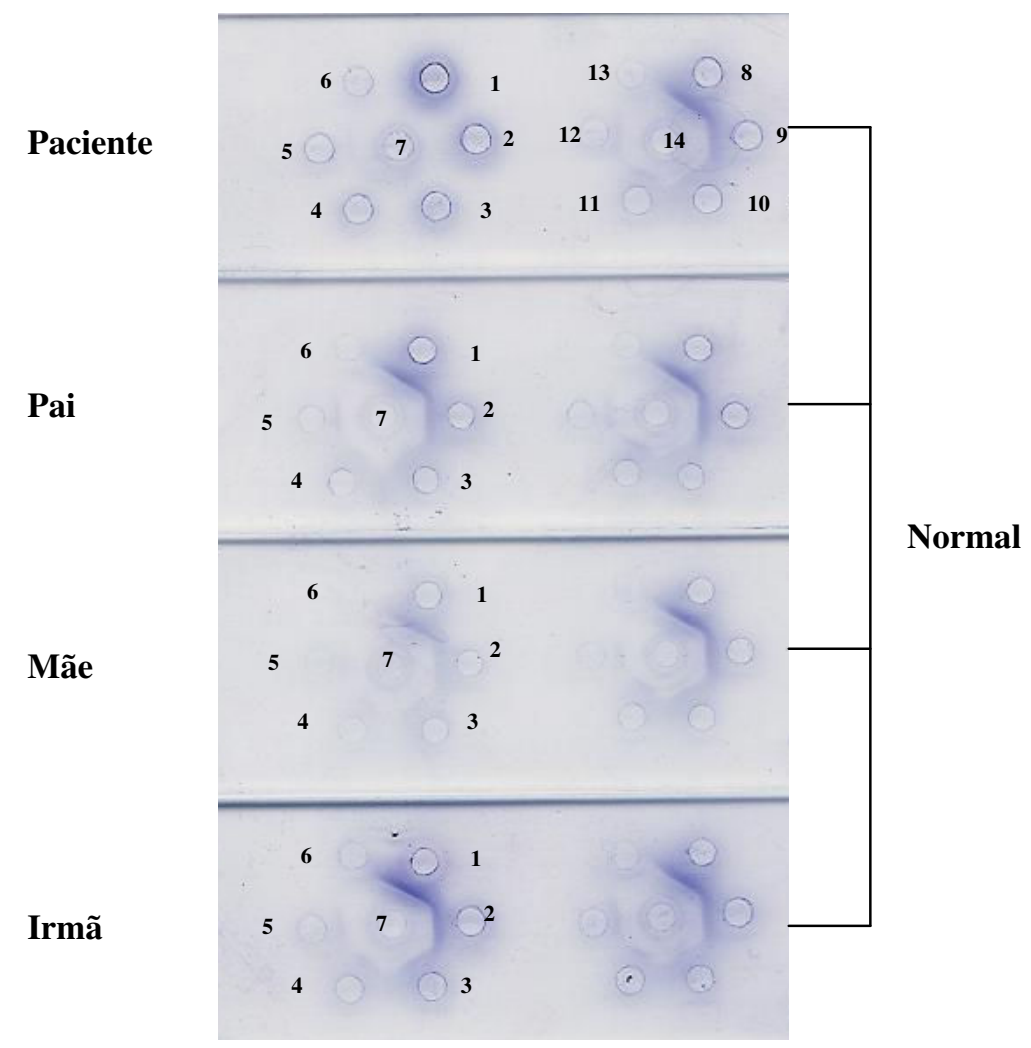

Figura 16: Avaliação da presença de C9 no soro do paciente e de seus familiares em comparação com o controle normal através da imunodifusão dupla. Soros do paciente e de seus familiares na forma não diluída (1), diluída a 1:2, 1:4, 1:8, 1:16 e 1:32 (2, 3, 4, 5 e 6 , respectivamente), anticorpo policlonal anti-C9 feito em cabra (7 e 14) e soro normal na forma não diluída (8) e diluída a 1:2, 1:4, 1:8, 1:16 e 1:32 (9, 10,11, 12 e 13, respectivamente).

A princípio, este resultado pareceu surpreendente, mas, uma vez que nosso paciente é descendente de japoneses e que a deficiência desta proteína acomete um indivíduo a cada 1000 dessa população, ficou evidente que havíamos encontrado uma deficiência concomitante, mas não necessariamente relacionada, à deficiência de FH previamente identificada.

De posse deste resultado, tornou-se indispensável a determinação da concentração de C9 no soro do paciente e de seus familiares por um método mais sensível, o ELISA, bem como a análise do perfil eletroforético desta proteína nos soros dos mesmos indivíduos, em 
comparação com o controle normal, pelo método Western Blot, a fim de investigar a presença de possíveis alterações estruturais nesta proteína.

5.5 Determinação da Concentração de C9 no Soro do Paciente e de Seus Familiares Utilizando o Método ELISA.

A concentração de C9 detectada no soro do paciente foi de 5,6 $\mu \mathrm{g} / \mathrm{ml}$ (Tabela 13), o que equivale a $17,5 \%$ da concentração encontrada no controle normal $(28,5 \mu \mathrm{g} / \mathrm{ml})$. Este resultado enquadra nosso paciente entre os deficientes deste componente e confirma a hipótese formulada na etapa anterior sobre a possível existência da deficiência desta proteína em concomitância com a deficiência de FH neste paciente.

Tabela 13: Concentração de C9 nos Soros do Paciente e de Sua Família.

\begin{tabular}{lc}
\hline \multicolumn{1}{c}{ Indivíduo } & C9 $(\boldsymbol{\mu g} / \mathbf{m l})$ \\
\hline Paciente & $5,6 \pm 0,34$ \\
Pai & $38,5 \pm 4,5$ \\
Mãe & $33,5 \pm 0,9$ \\
Irmã & $30 \pm 0,5$ \\
Normal (média) & 28,5 \\
$\begin{array}{l}\text { Normal } \\
\text { (faixa de normalidade) }\end{array}$ & $22-35$ \\
\hline
\end{tabular}

A concentração de C9 detectada no soro do pai do paciente $(38,5 \mu \mathrm{g} / \mathrm{ml})$ está sutilmente acima dos níveis encontrados no controle normal. Já nos soros da mãe e irmã, 
foram encontradas concentrações normais deste componenete, 33,5 $\mu \mathrm{g} / \mathrm{ml}$ e $30 \mu \mathrm{g} / \mathrm{ml}$, respectivamente.

Vale ressaltar ainda que a concentração de C9 detectada no soro normal foi determinada em diferentes amostras contendo uma de mistura de soros pertencentes a indivíduos normais (47 e 130 indivíduos), e ainda em amostras simples de indivíduos normais, em quatro diferentes ensaios de ELISA. Ainda assim, o valor obtido é inferior ao registrado na literatura como concentração de referência $(60 \mu \mathrm{g} / \mathrm{ml})$, levantando a hipótese de que esta proteína encontra-se em concentrações inferiores na população brasileira quando comparada a outras populações.

Tentando endossar essa hipótese nós medimos a concentração de C9 em 31 diferentes amostras de soros de indivíduos normais não relacionados, a fim de detectar primariamente a faixa de normalidade da concentração desta proteína na população brasileira. As concentrações variaram entre $12,2 \mu \mathrm{g} / \mathrm{ml}$ e $41,9 \mu \mathrm{g} / \mathrm{ml}$, com média de $28,5 \mu \mathrm{g} / \mathrm{ml}$ e desvio padrão de 6,5. Este resultado nos leva a sugerir que a concentração de C9 na população brasileira é aparentemente menor do que a concentração detectada em outras populações.

\subsection{Avaliação do Perfil do C9 no Soro do Paciente e de Sua Família Pelo Western Blot.}

Tendo detectado o C9 em concentrações residuais no paciente através do método ELISA, e sabendo da alta freqüência de indivíduos deficientes de C9 na população japonesa, da qual o nosso paciente é descendente, decidimos então avaliar a presença e o perfil desta proteína no soro do paciente através de um método mais sensível, como o Western Blot.

Pudemos observar que a proteína C9 $(70 \mathrm{kDa})$ está presente no soro do paciente, mas em concentração aparentemente muito reduzida, se comparada à encontrada no soro controle ou mesmo nos soros de seus familiares (Figura 17), dado que concorda com a concentração da proteína detectada no soro do paciente pelo ELISA. Entretanto, a proteína apresenta-se 
com peso molecular e perfil de migração em gel semelhantes aos exibidos pela proteína detectada no soro controle.

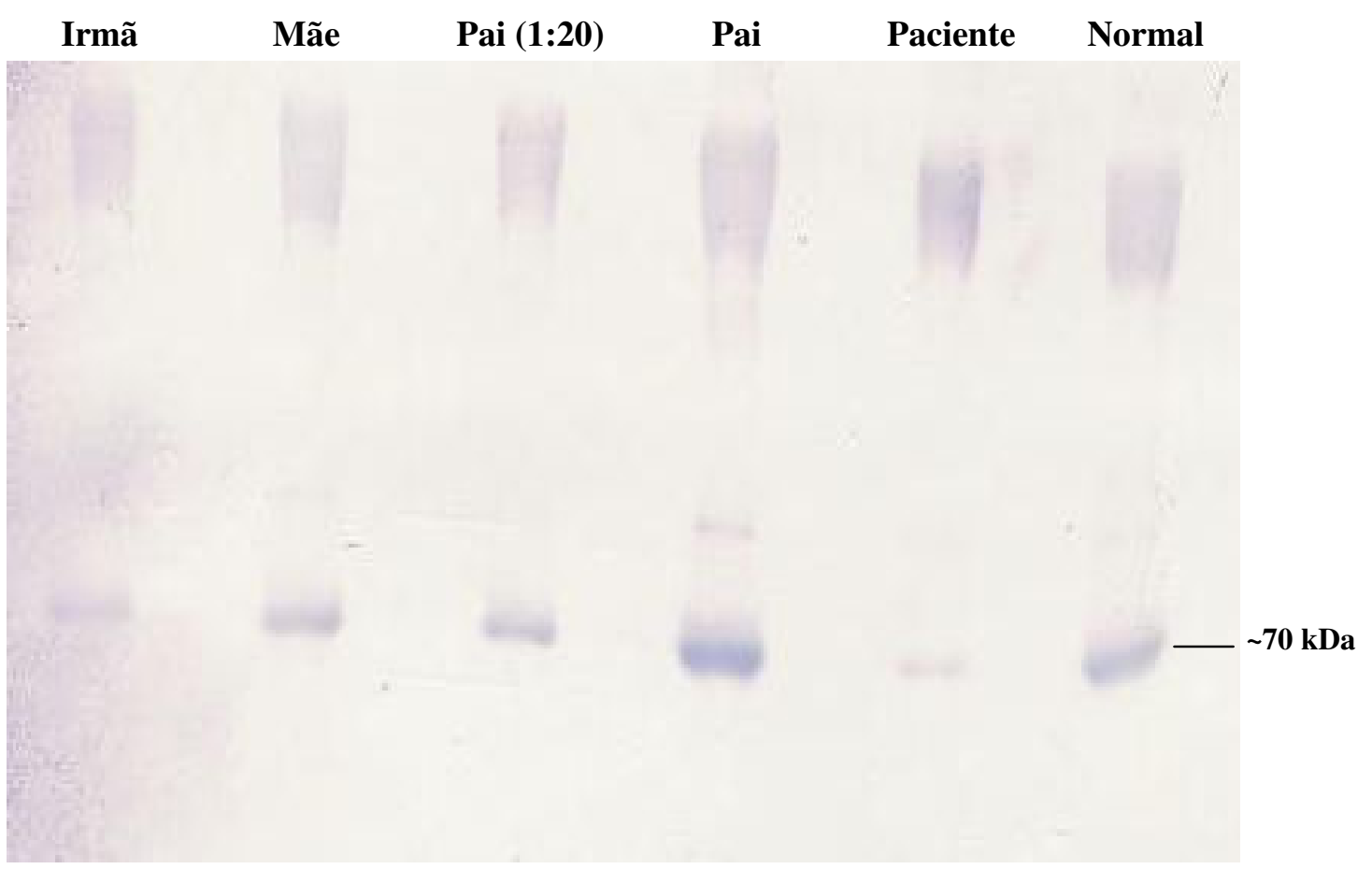

Figura 17: Análise do perfil do C9 presente no soro do paciente e de sua família através de Western Blotting utilizando anticorpo policlonal de cabra anti-C9 humano como primário. Todos os soros foram utilizados na diluição 1:10, com exceção do soro do pai que foi também diluído a 1:20.

No soro do pai do paciente pudemos observar que o C9 está presente em concentração aparentemente elevada, não só quando comparada com a proteína detectada no soro do paciente, mas também quando comparada à encontrada no soro controle. Apenas quando o seu soro foi diluído duas vezes mais que os demais soros (linha 3) foi possível aproximar a quantidade de C9 encontrada no seu soro à detectada no soro da mãe do paciente. Este resultado está de acordo com a concentração de proteína detectada no soro do pai pelo método ELISA. 
Já no soro da mãe e irmã, o C9 detectado apresenta-se em concentração aparentemente semelhante à encontrada no soro controle. Este dado também está de acordo com as concentrações de C9 nos soros da mãe e irmã determinadas pelo método ELISA.

Encerradas as etapas de avaliação funcional do C, de determinação das concentrações das proteínas pertencentes a esse sistema no soro do paciente e de seus familiares, em comparação com o controle normal, bem como de avaliação dos aspectos estruturais das proteínas encontradas em deficiência nesses soros, decidimos partir para outro nível do projeto, a fim de avaliarmos as bases moleculares dessas deficiências. Assim, iniciamos os procedimentos que nos permitiriam analisar o material genético do paciente e de seus familiares na busca por alterações não encontradas em indivíduos normais e que pudessem ser responsáveis pelas deficiências em questão, procedimentos estes que serão descritos a partir deste momento.

\subsection{Amplificação do cDNA do FH do Paciente}

O primeiro passo na caracterização molecular da deficiência de $\mathrm{FH}$ no nosso paciente foi utilizar a cultura de seus fibroblastos como fonte de RNA total para RT-PCRs específicos. Vale ressaltar que, mesmo sendo de nosso conhecimento que fibroblastos não são a principal fonte de $\mathrm{FH}$, e sim o fígado, a facilidade de obtenção do material, a partir de uma pequena incisão externa sob anestesia local, em oposição ao que ocorreria numa coleta de hepatócitos, impulsionou-nos a fazer de tais células as mais adequadas para o fornecimento desse material. Também temos ciência de que células sangüíneas, monócitos, por exemplo, seriam possivelmente fontes mais ricas de $\mathrm{FH}$ do que os fibroblastos, entretanto, a necessidade de punção venosa freqüente, na tentativa de obtenção de material para realização dos ensaios, desencorajou-nos de escolhê-las como fonte desse material. 
Diante disso, o RNA foi extraído e quantificado de acordo com o que foi descrito na seção de Materiais e Métodos e procedeu-se com a caracterização molecular da deficiência do paciente em questão.

Usando, então, o RNA total do paciente e de um indivíduo normal, nós amplificamos vários fragmentos do cDNA de $\mathrm{FH}$ (como esquematizado na Figura 13) do paciente e comparamos com os fragmentos obtidos de um controle normal após eletroforese em gel de agarose (Figura 18). Todos os fragmentos amplificados do paciente apresentaram tamanho e intensidade equivalentes àqueles obtidos com cDNA de um indivíduo normal. Esta observação indica a ausência de grandes deleções ou inserções no RNAm de FH do probando.

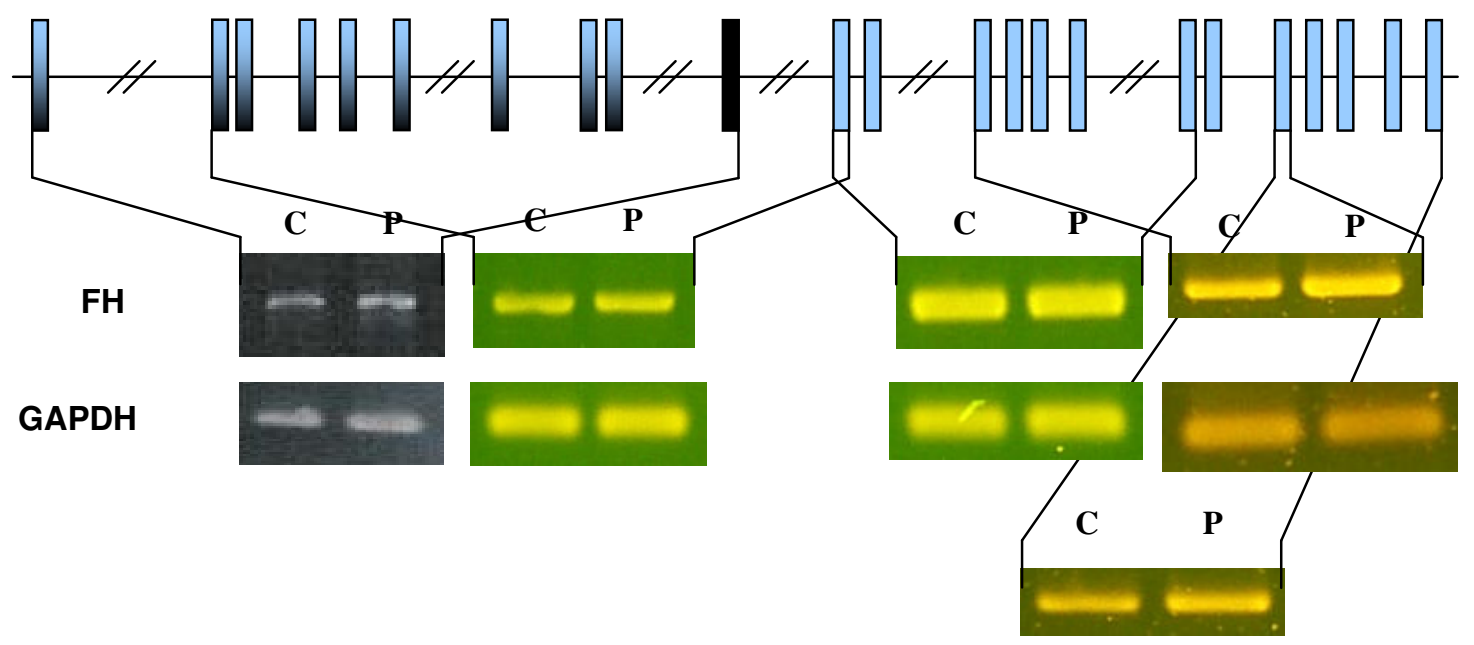

Figura 18: Análise de fragmentos do cDNA de FH do paciente e de um controle normal amplificados por RT-PCR. C: fragmento amplificado de um indivíduo controle, P: fragmento amplificado do paciente.

\subsection{Seqüenciamento do cDNA de FH do Paciente}

Todos os fragmentos obtidos do cDNA de FH do paciente foram seqüenciados como descrito nos Materiais e Métodos e as seqüências obtidas comparadas com as depositadas no 
site http://www.ncbi.nlm.nih.gov/blast, utilizando o programa BLAST N (Altschul et al, 1997) tendo por base a referência /NM Y00716/HF1/Homo sapiens complement Factor H (FH) $m R N A$ (Ripoche et al, 1988).

A primeira alteração encontrada foi a substituição de um nucleotídeo na posição G453A em ambos os alelos. Esta substituição altera o códon $\left(\mathrm{CG}^{\mathbf{4 5 3}} \mathrm{T} \rightarrow \mathrm{CA}{ }^{\mathbf{4 5 3}} \mathrm{T}\right)$ de tal forma que a His ${ }^{127}$ é substituída pela $\operatorname{Arg}^{127}$ (Figura 19). Vale a pena ressaltar que o nucleotídeo 453 localiza-se no SCR-2 da proteína FH, também encontrado no FHL-1.

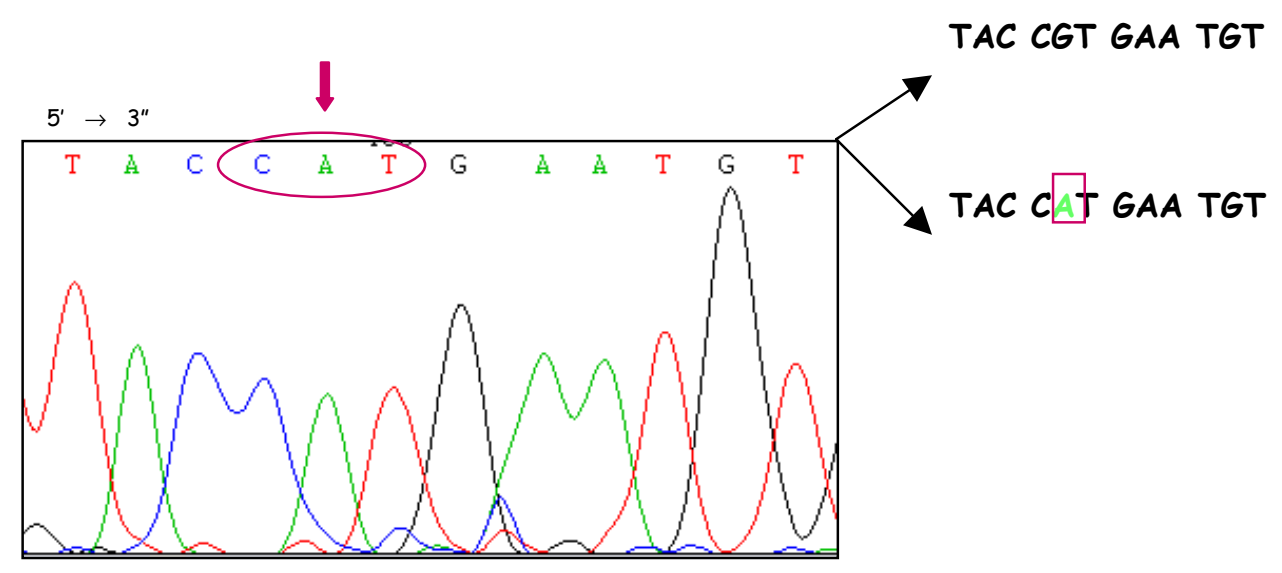

Figura 19: Alteração molecular encontrada no cDNA de $\mathrm{FH}$ do paciente de forma homozigota. Substituição de um nucleotídeo na posição 453 (G453A) alterando o códon de uma Arg para uma His.

A segunda alteração encontrada foi uma segunda substituição de nucleotídeo de forma homozigota, desta vez na posição 2089 (A2089G) (Figura 20A). Esta segunda alteração modificou o códon de $\mathrm{CAA}^{\mathbf{2 0 8 9}}$ para $\mathrm{CAG} \underline{\mathbf{G}}^{\mathbf{2 0 8 9}}$, mas não modificou o resíduo de aminoácido a ser codificado, uma Glu na posição 672 do SCR-11, sendo, portanto uma mutação silenciosa, descrita como polimorfismo por Neumann et al, 2003.

A última alteração encontrada também foi a substituição de um nucleotídeo e também de forma homozigota, mas agora na posição 2881 (G2881A) (Figura 20B). Como na mutação 
anterior, esta substituição causa modificações no códon respectivo $\left(\mathrm{GA}^{\mathbf{2 8 8 1}} \mathrm{G} \rightarrow \mathrm{GA}^{\mathbf{2 8 8 1}} \mathrm{A}\right)$, mas desta vez com modificação do resíduo de aminoácido codificado, sendo codificada uma Asp em substituição à Glu na posição 936 do SCR-15. Esta mutação já foi previamente descrita por Neumann e seus colaboradores em 2003 (Neumann et al, 2003) como um polimorfismo e foi fortemente associada à SHU no estudo conduzido por Caprioli e seus colaboradores no mesmo ano (Caprioli et al, 2003).
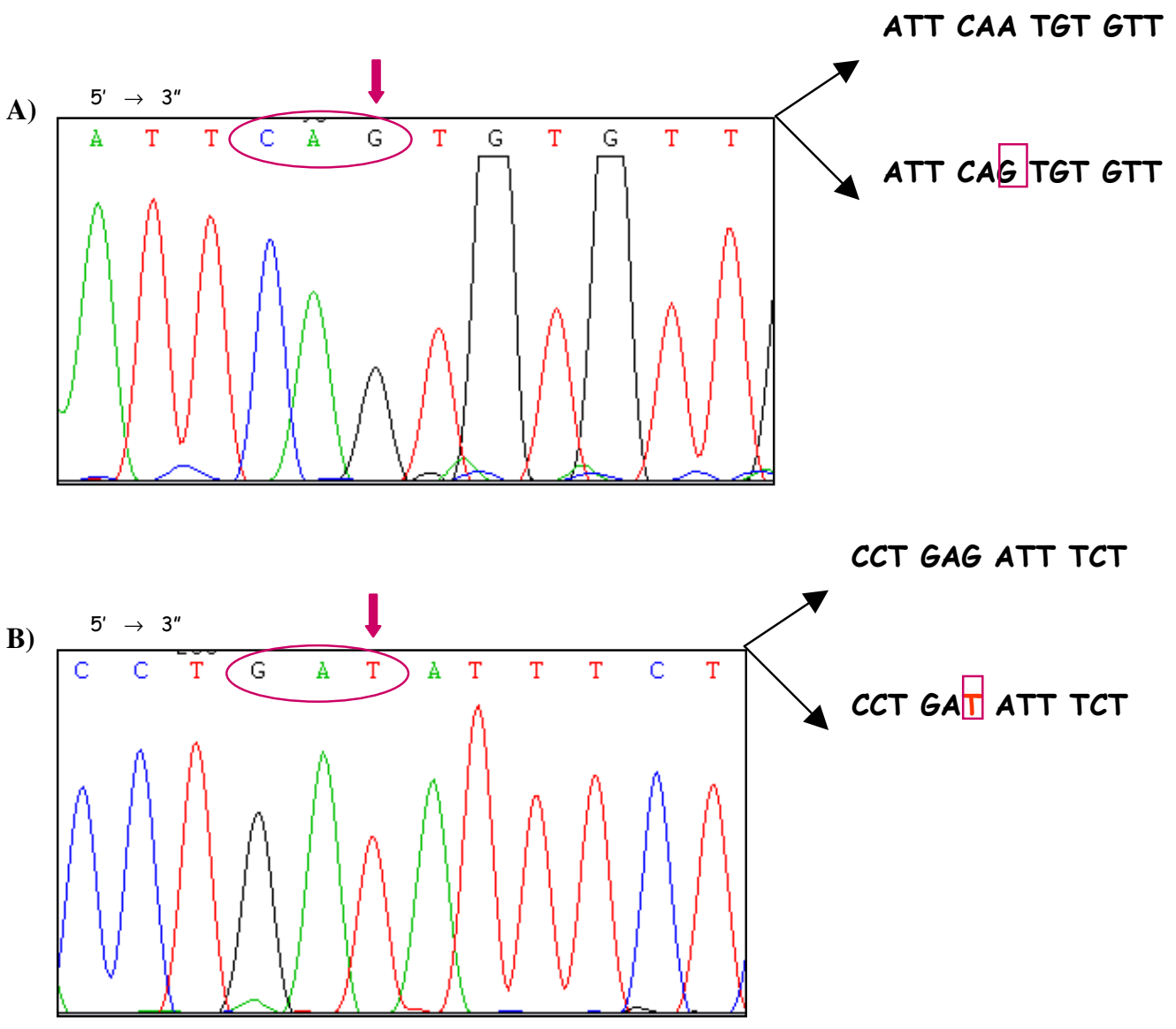

Figura 20: Alterações moleculares encontradas no cDNA de FH do paciente. A) Substituição silenciosa de um nucleotídeo na posição 2089 (A2089G) com conservação do resíduo de Glu na posição 672; B) Substituição de um nucleotídeo na posição 2881 (G2881T) alterando o códon de uma Glu para uma Asp na posição 936 (polimorfismo descrito por Neumann e colaboradores em 2003). 
A fim de confirmar o perfil hereditário da mutação homozigota encontrada na posição 453 do cDNA do paciente, amplificamos e seqüenciamos a porção do DNA genômico da mãe do paciente em que está contido o nucleotídeo 453. A mesma mutação foi identificada no DNA genômico da mãe e surpreendentemente também na forma homozigota. Uma vez que no paciente esta mutação seria a provável responsável pela ausência de FH e de FHL-1 no seu soro parece contraditório que a mãe carregue a mesma mutação e ainda disponha das duas proteínas (Figura 21).

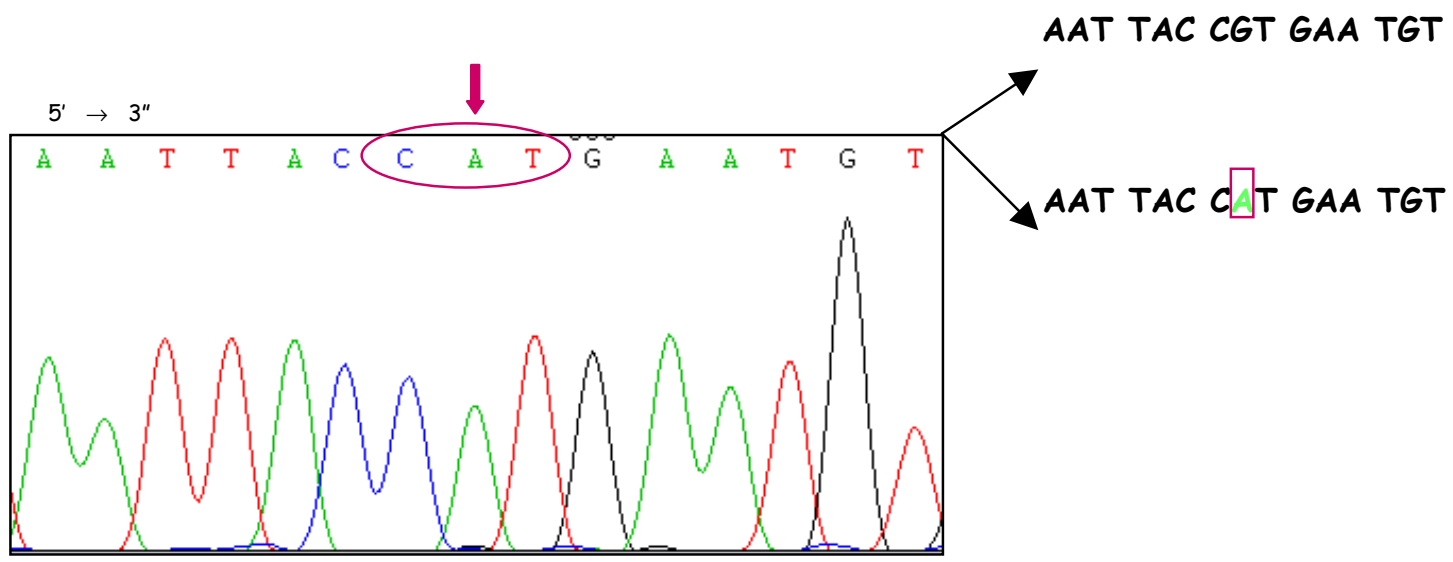

Figura 21: Alteração molecular encontrada no nos dois alelos do DNA genômico de FH da mãe do paciente. Substituição de um nucleotídeo na posição $453(\mathrm{G} \rightarrow \mathrm{A})$ alterando o códon de uma Arg para uma His.

Avaliando, por sua vez, o DNA genômico do pai do paciente observamos a presença da mesma mutação, entretanto, em apenas um dos alelos, enquanto o outro apresentou a mesma seqüência de nucleotídeos encontrada num indivíduo normal (Figura 22). 


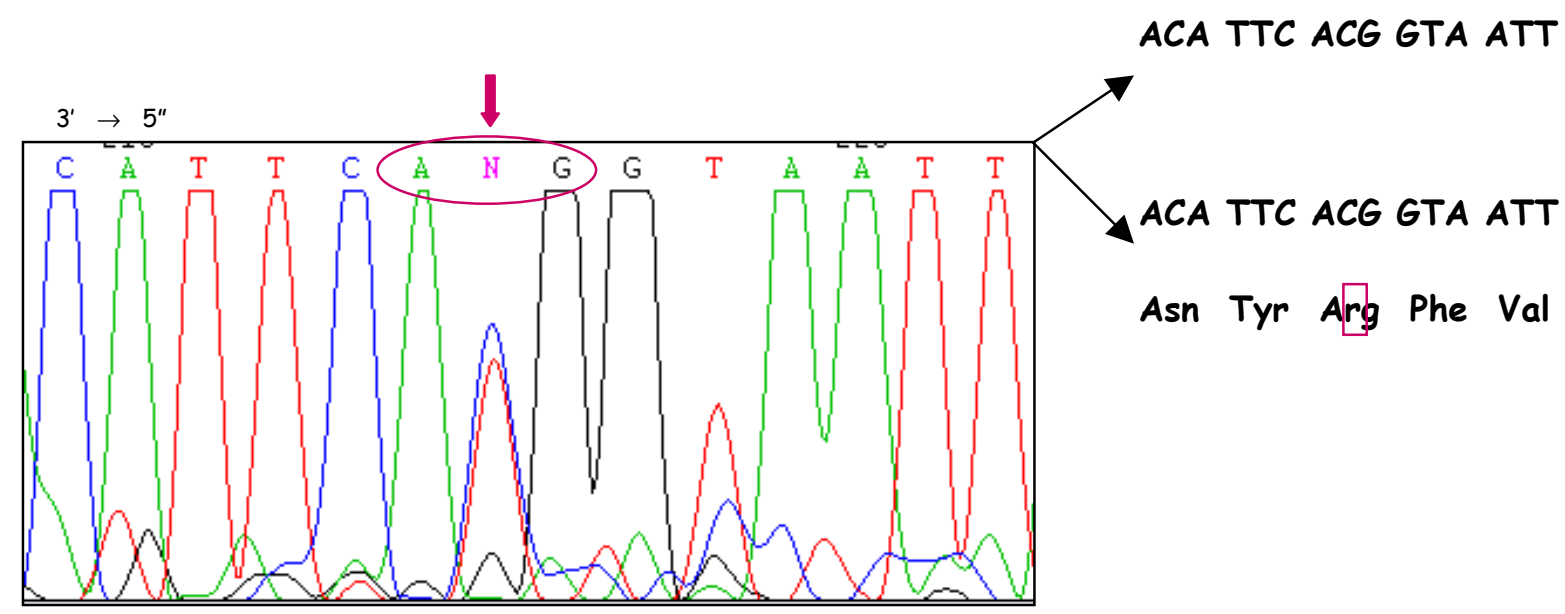

Figura 22: Alteração molecular encontrada em um dos alelos do DNA genômico de FH do pai do paciente. Substituição de um nucleotídeo na posição $453(\mathrm{C} \rightarrow \mathrm{T})$ alterando o códon de uma Arg para uma His.

\subsection{Amplificação Éxon-específica do DNA Genômico de C9 do Paciente}

Várias tentativas de amplificar porções do cDNA de C9 do paciente a partir de amostras de RNA total extraídas de seus fibroblastos foram levadas a efeito, mas sem sucesso. Estas tentativas infrutíferas sugerem que fibroblastos não são uma boa fonte de RNA mensageiro para C9, talvez por não o produzirem em grandes concentrações. Assim, baseados nessa hipótese e amparados pela ampla literatura disponível sobre o uso de DNA genômico para o estudo do gene de $C 9$ optamos pela amplificação dos éxons do gene de acordo com Witzel-Schlömp et al, 1997; 2001.

A partir do DNA genômico extraído de fibroblastos do paciente e utilizando pares de oligonucleotídeos éxon-específicos, que permitiram a amplificação de pelo menos vinte nucleotídeos das porções intrônicas, amplificamos os 11 éxons do DNA de C9 do paciente e comparamos os fragmentos obtidos com os obtidos a partir do DNA de um indivíduo controle (Figura 23). Todos os fragmentos amplificados do paciente apresentaram tamanhos e 
intensidade equivalentes aos do obtidos com DNA de um indivíduo normal. Esta observação indica a ausência de grandes deleções e inserções no DNA de C9 do probando.

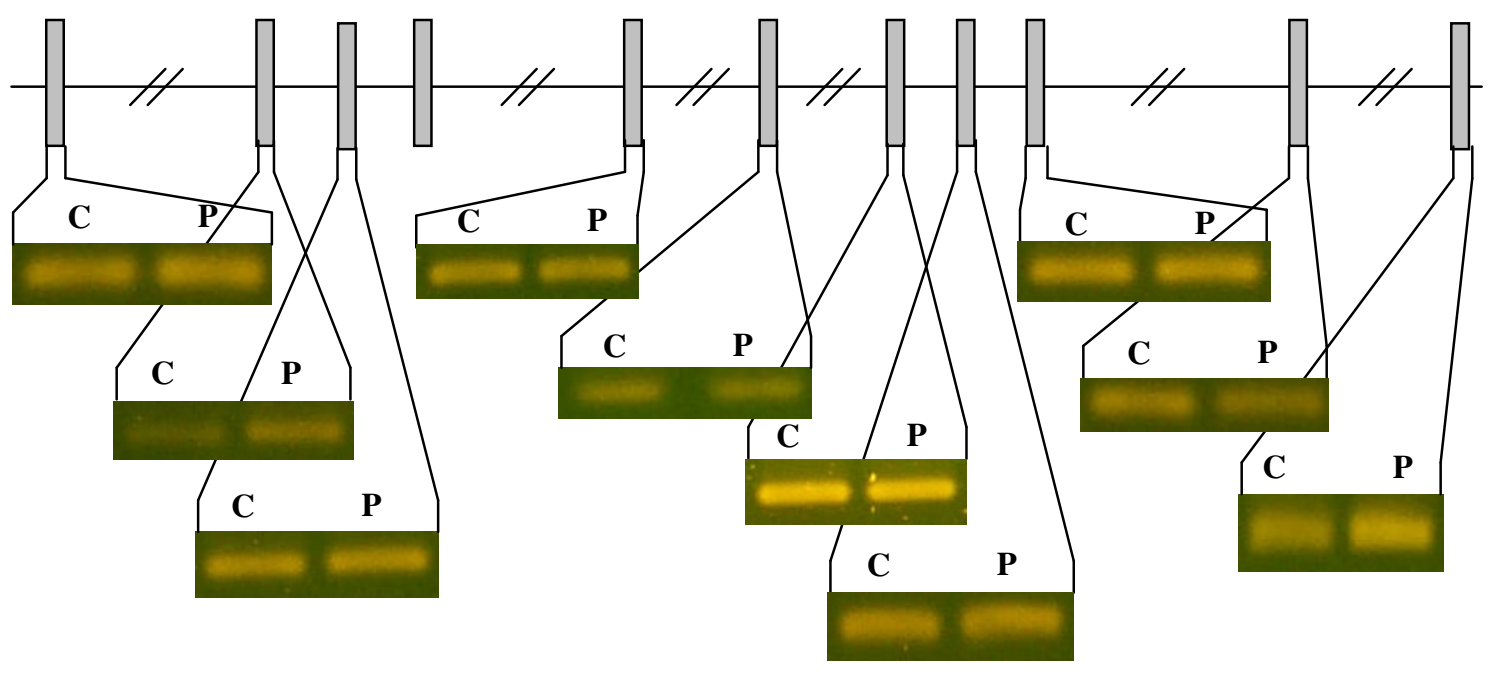

Figura 23: Análise de fragmentos éxon-específicos, amplificados por PCR, do DNA de C9 do paciente em comparação com um controle normal. C: fragmento amplificado de um indivíduo controle, P: fragmento amplificado do paciente.

5.10 Seqüenciamento dos Éxons e Pequenas Porções dos Íntrons do DNA genômico para C9 do Paciente

Como feito para o cDNA do $\mathrm{FH}$, todos os fragmentos obtidos foram seqüenciados e as seqüências obtidas comparadas com as depositadas no site http://www.ncbi.nlm.nih.gov/blast, utilizando o programa BLAST N (Altschul et al, 1997) tendo por base a referência /NM 001737.2/Homo sapiens complement C9 mRNA (DiScipio et al, 1984).

Já no íntron 1 foi detectada a substituição de um nucleotídeo $(\mathrm{G} \rightarrow \mathrm{A})$ na posição 39315066 do DNA genômico (Schmutz et al, 2004) (Figura 24), mutação esta que não modifica o sítio de splicing. Esta alteração já foi descrita como um polimorfismo por WitzelSchlömp et al em 2001 (Witzel-Schlömp et al, 2001). No éxon 1 foi encontrada em um dos alelos a substituição de um nucleotídeo na posição 17 (C17T) (Figura 24) alterando o códon 
$\left(C \underline{\mathbf{C}}^{17} \mathrm{G} \rightarrow \mathrm{C} \underline{\mathbf{T}}^{17} \mathrm{G}\right)$ e o aminoácido codificado na posição 5 , Trp em substituição à Arg. Esta mutação também já foi descrita como um polimorfismo (Witzel-Schlömp et al, 2001). Uma outra substituição de nucleotídeo foi encontrada no éxon 11 na posição 1975 (C1975T) $\left(\mathrm{A} \underline{\mathbf{C}}^{1975} \mathrm{~T} \rightarrow \mathrm{AT} \underline{\mathbf{T}}^{1975} \mathrm{~T}\right)($ Figura 9C). Esta alteração também foi anteriormente descrita como um polimorfismo por Witzel-Schlömp et al (Witzel-Schlömp et al, 2001). 

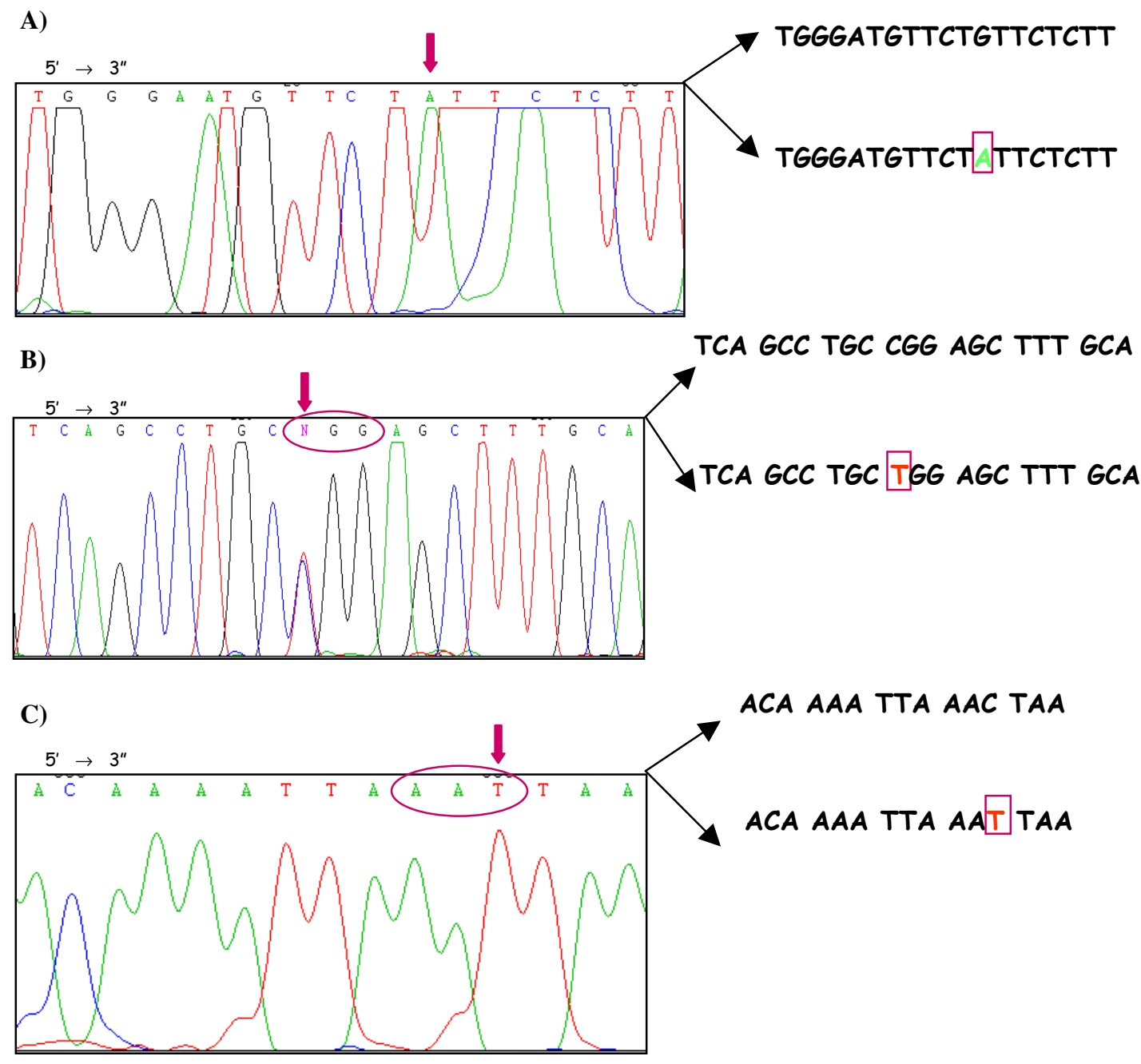

Figura 24: Polimorfismos encontrados no DNA genômico do paciente na região do gene $C 9$. A) Substituição de um nucleotídeo $(C \rightarrow T)$ na posição 39315066 sem alteração do sítio para splicing; B) Substituição de um nucleotídeo na posição 17 (C17T) do éxon 1 com substituição de uma Arg pelo Trp na posição 5; C) Substituição de um nucleotídeo na posição 1975 (A1975T) do éxon 11 com conservação do aminoácido Asn.

Diante da suposição de que as alterações encontradas no gene $F H$ do paciente modificariam o perfil de secreção e/ou expressão do FH pelas células do paciente, decidimos avançar mais uma etapa no projeto e utilizar um método que permitisse a avaliação da presença ou ausência desta proteína no compartimento intracelular do paciente em 
comparação com o perfil encontrado nas células de um indivíduo normal. O método escolhido para realização de tal etapa foi a Microscopia Confocal.

A microscopia confocal possibilita a visualização de proteínas que estejam armazenadas dentro das células pela utilização de anticorpos conjugados com moléculas fluorescentes (que, neste ensaio, emitem luz de cor verde) e que, após solubilização das membranas dessas células, conseguem atingir o espaço intracelular. A fim de melhor visualizar e dimensionar o espaço intracelular, optamos pela utilização adicional do iodeto de propídeo, que cora somente material nuclear e emite luz vermelha.

\subsection{Avaliação do FH Intracelular em Fibroblastos do Paciente por Microscopia Confocal.}

Os resultados mostram a presença de FH (verde) nas células do paciente (Figura 25) em intensidade semelhante, ou mesmo mais intensa, que a detectada nas células do indivíduo normal. Este dado indica que os mecanismos responsáveis pela produção (expressão) do FH estão intactos, a ponto de podermos concluir que, apesar das alterações moleculares no gene $F H$, as células do paciente continuam sendo capazes de produzir a proteína. Contudo, a ausência de FH no espaço extracelular (por exemplo soro) leva-nos a propor que as células do paciente são capazes de produzir esta proteína, sem contudo secretá-la na mesma velocidade que células de indivíduos normais o fazem. 
Controle negativo

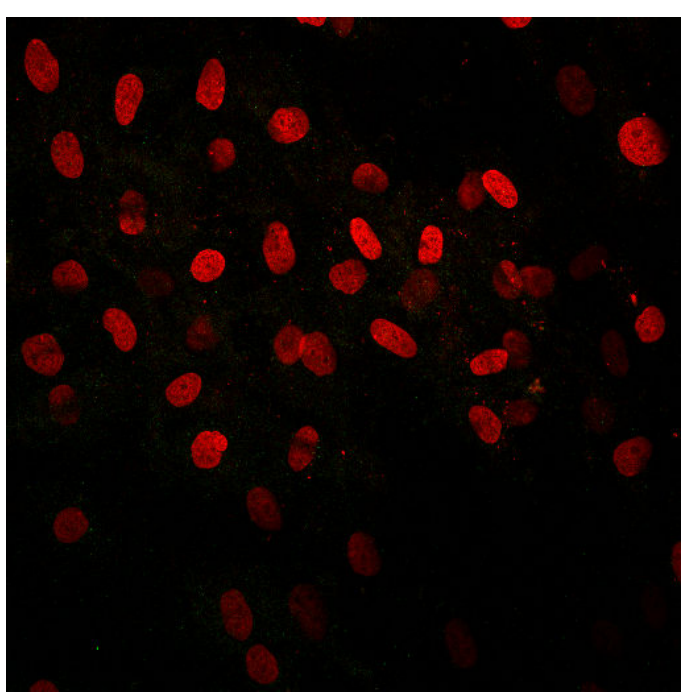

A)

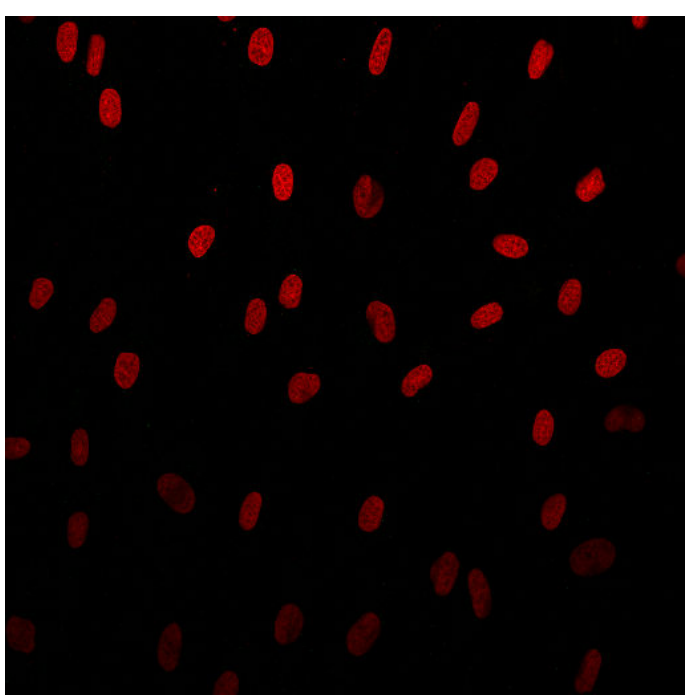

C)
FH

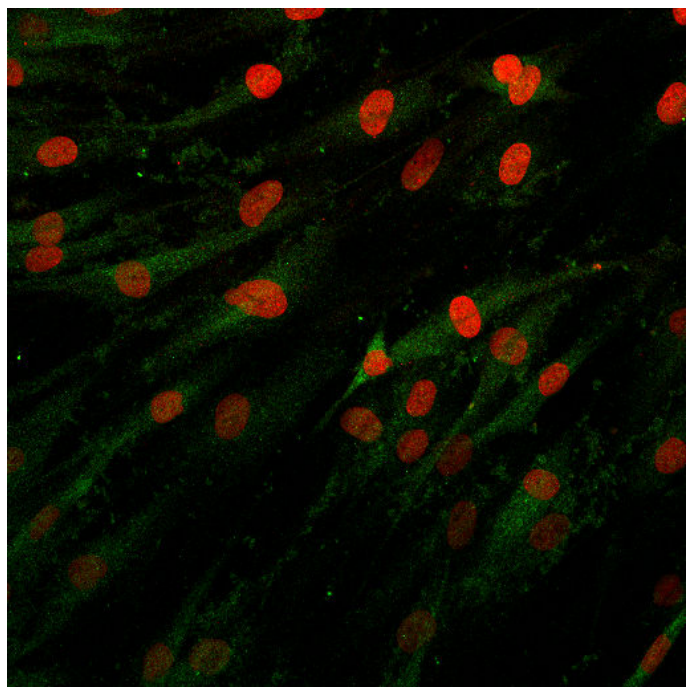

B)

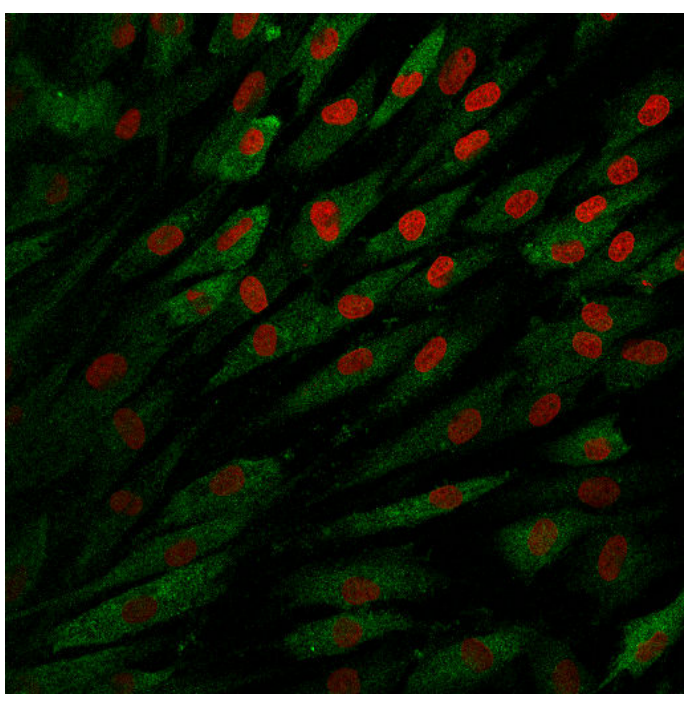

D)

Figura 25: Presença de FH no citoplasma de fibroblastos observados por microscopia confocal. A) e C) Controle negativo: células do indivíduo normal (A) e do paciente (C) marcadas somente com iodeto de propídio (vermelho) e anticorpo anti-IgG de coelho marcado com FITC (anticorpo secundário); B) e D) Células do indivíduo normal (B) e do paciente (D) marcadas com iodeto de propídio (vermelho) e anticorpo policlonal anti-FH humano feito em coelho (anticorpo primário). 
Diferentemente dos fibroblastos do paciente, os fibroblastos de sua mãe apresentam uma marcação de FH menos intensa que a exibida pelas células indivíduo normal (Figura 26), dado condizente com a concentração de FH encontrada no seu soro. Equivalentes resultados foram observados com fibroblastos do pai e irmã (Figura 27). 
Controle negativo

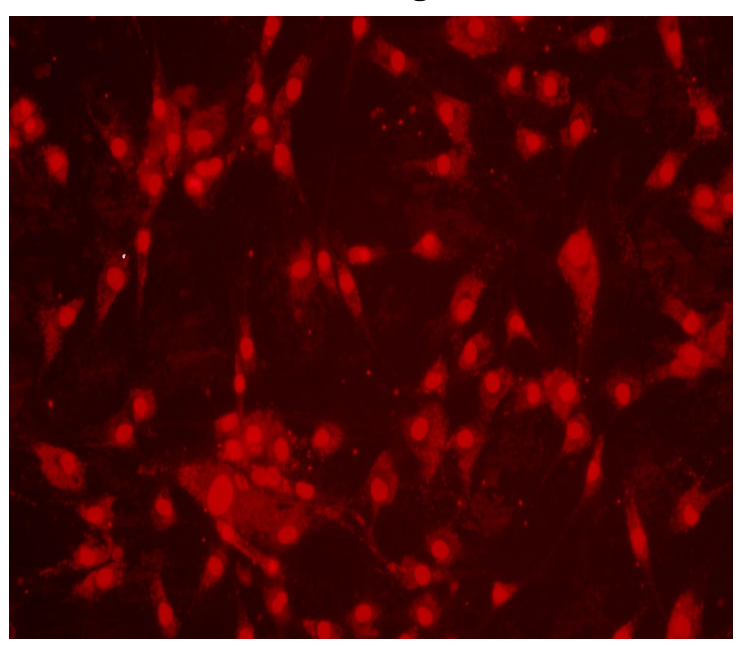

A)

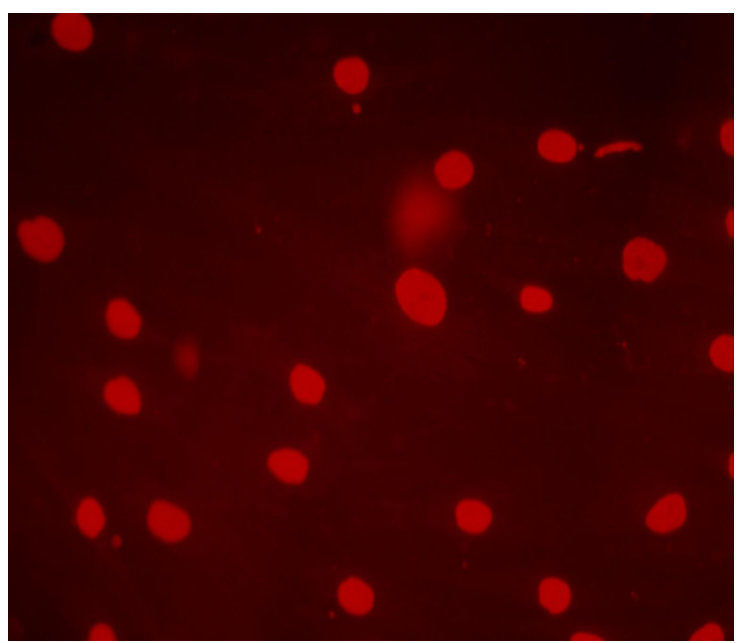

C)
FH

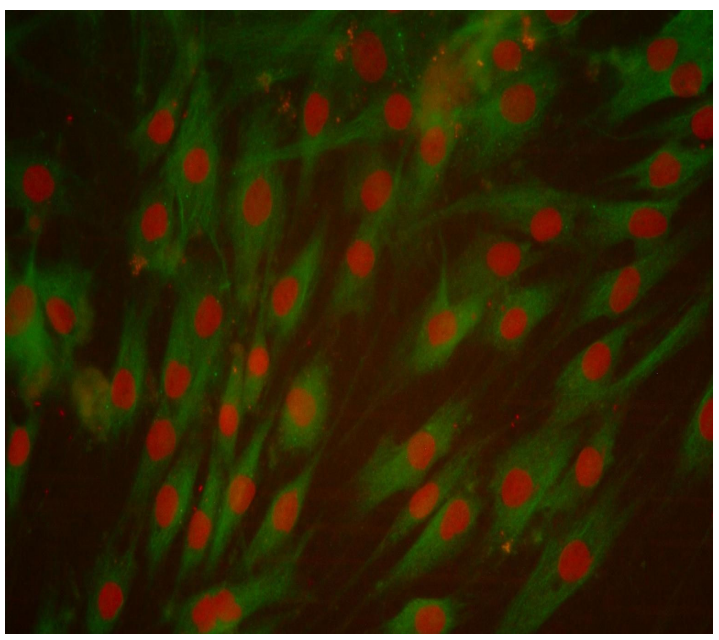

B)

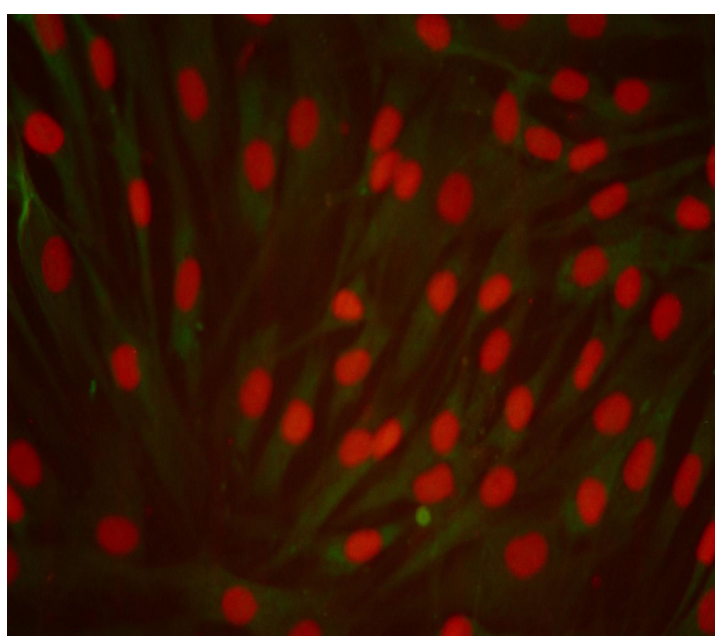

D)

Figura 26: Presença de FH no citoplasma de fibroblastos observados por fluorescência. A) e C) Controle negativo: células do indivíduo normal (A) e da mãe do paciente (C) marcadas somente com iodeto de propídio (vermelho) e anticorpo anti-IgG de coelho marcado com FITC (anticorpo secundário); B) e D) Células do indivíduo normal (B) e da mãe do paciente (D) marcadas com iodeto de propídio (vermelho) e anticorpo policlonal anti-FH humano feito em coelho (anticorpo primário). 
Controle negativo

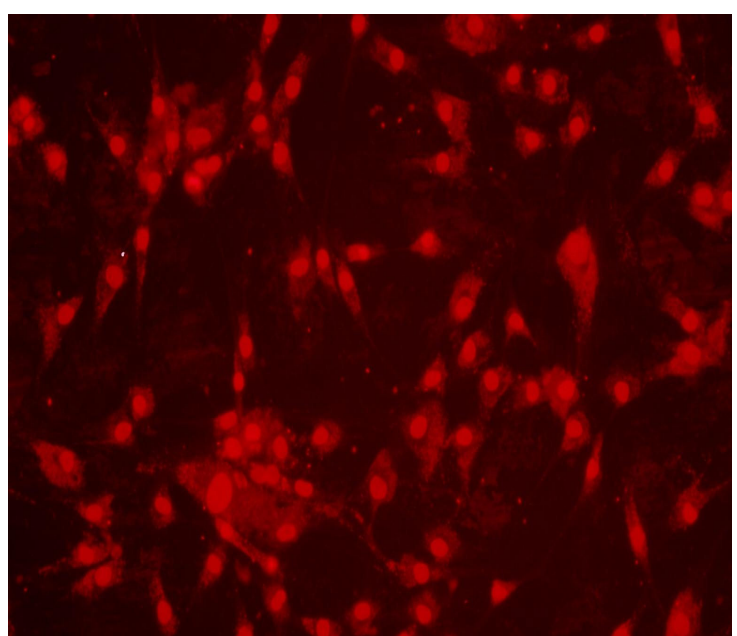

A)

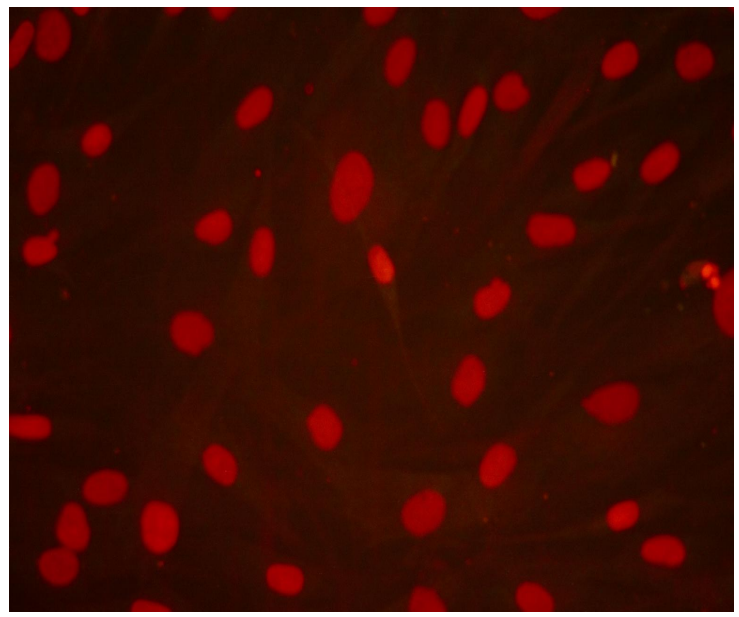

C)

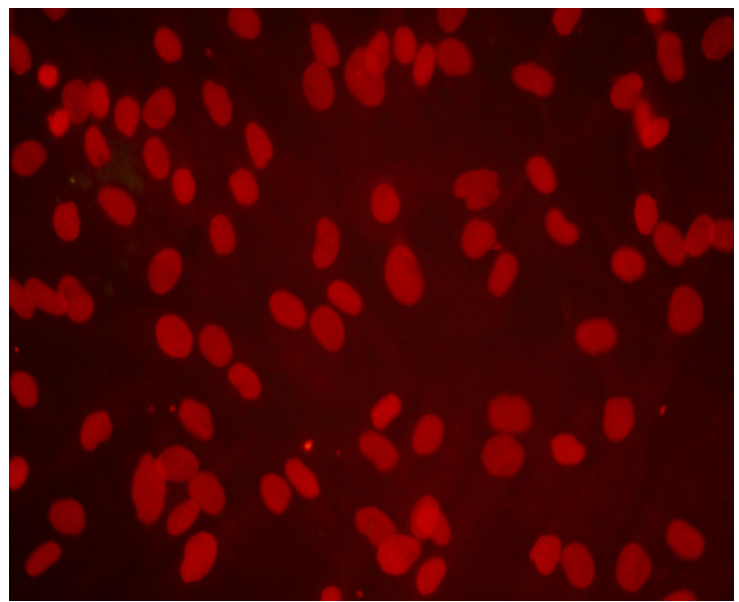

E)
FH

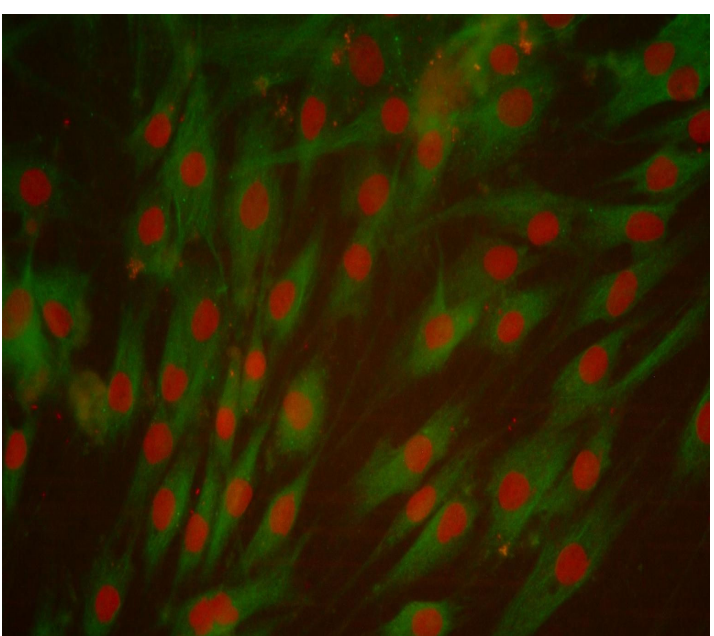

B)

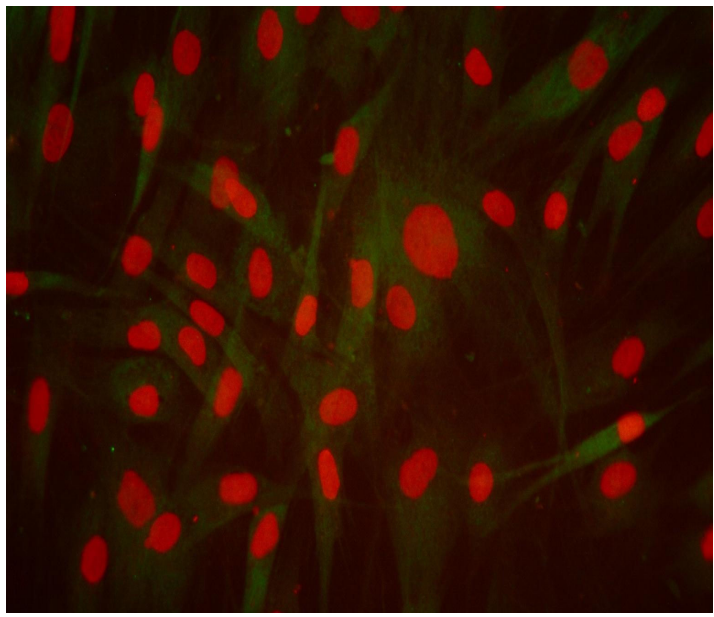

D)

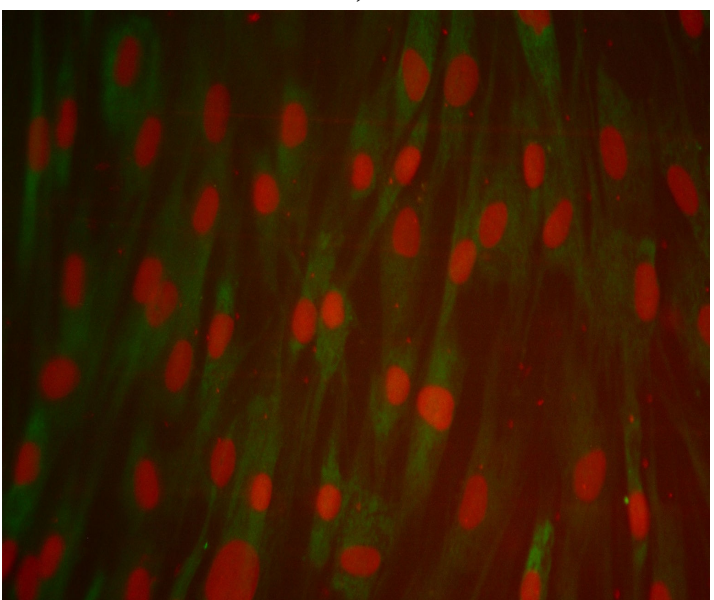

F)

Figura 27: Presença de FH no citoplasma de fibroblastos observados por fluorescência. A), C) e E) Controle negativo: células do indivíduo normal (A), do pai (C) e da irmã do paciente (E) marcadas somente com iodeto de propídio (vermelho) e anticorpo anti-IgG de coelho marcado com FITC (anticorpo secundário); B), D) e F) Células do indivíduo normal (B) do pai (D) e da irmã do paciente (F) marcadas com iodeto de propídio (vermelho) e anticorpo policlonal antiFH humano feito em coelho (anticorpo primário). 
5.12 Avaliação do C9 Intracelular em Fibroblastos do Paciente por Microscopia Confocal.

Os resultados mostram uma marcação referente à presença de C9 nos fibroblastos do paciente menos intensa do que a exibida pelo indivíduo normal (Figura 28). Este resultado é condizente com a baixa concentração deste componente encontrada no soro do paciente.

Já nos fibroblastos da mãe (Figura 28 E e F), do pai e irmã do paciente (Figura 29) a marcação referente à presença de C9 foi equivalente àquela exibida pelas células do indivíduo normal. 
Controle negativo

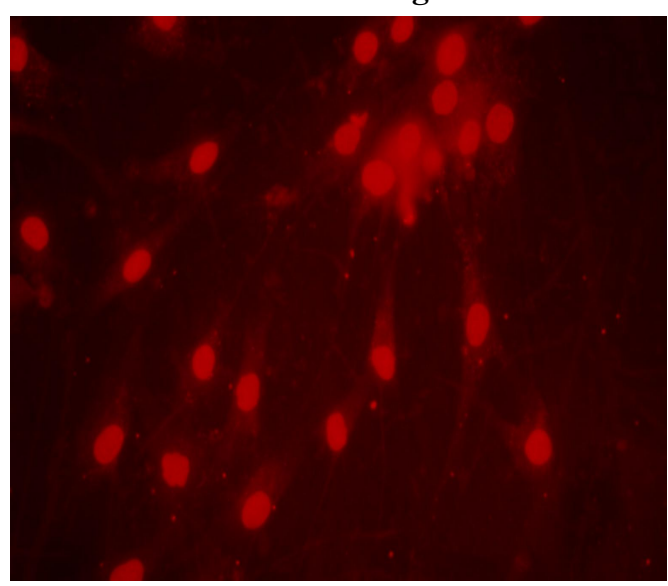

A)

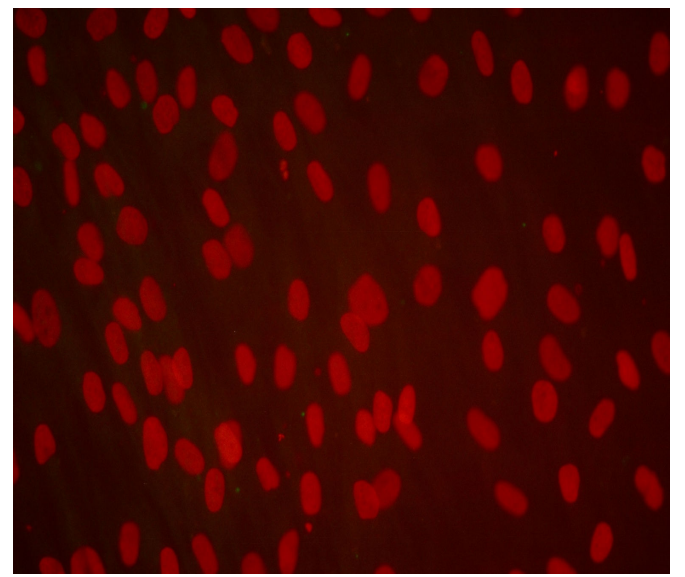

C)

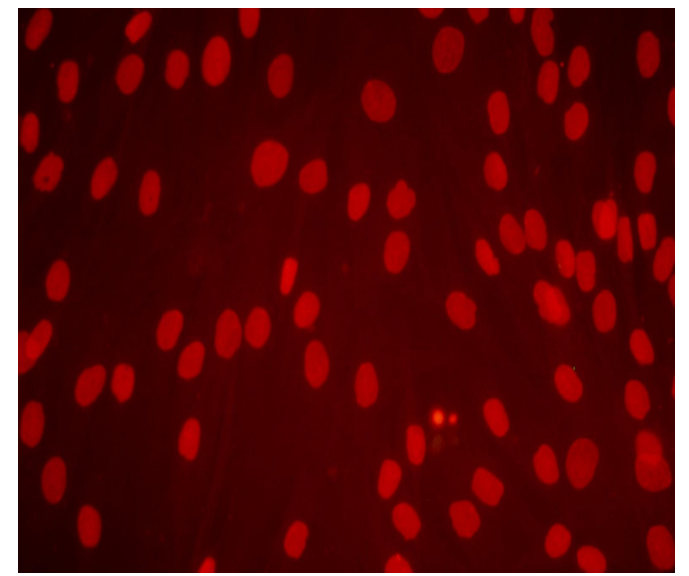

E)
C9

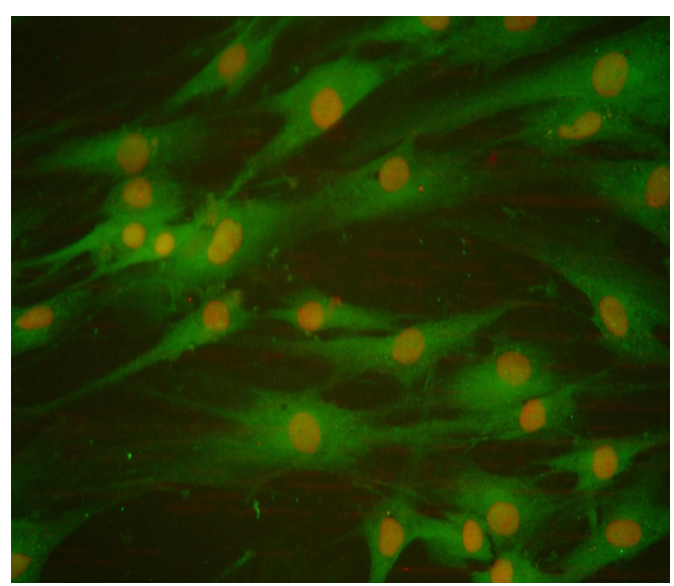

B)

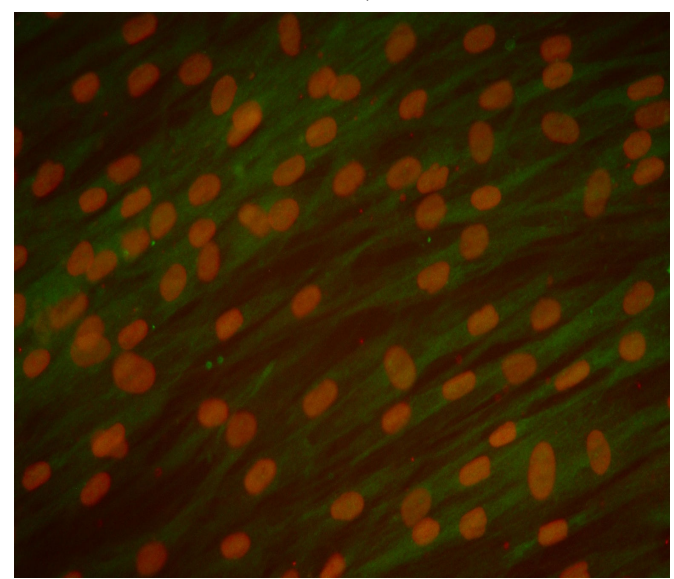

D)

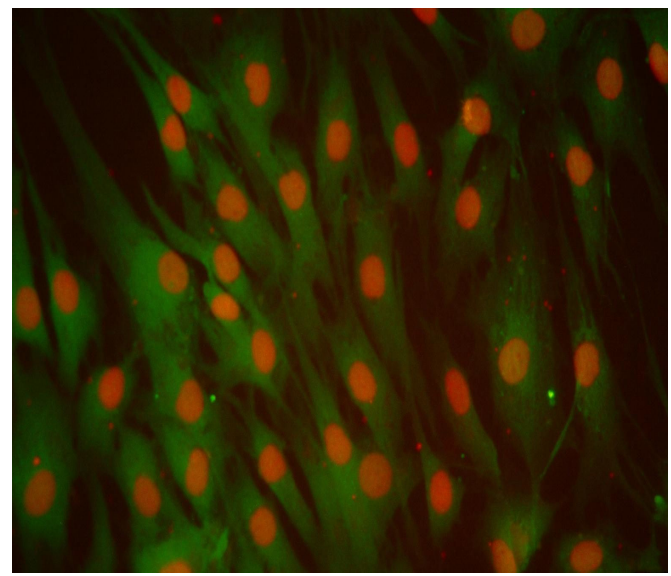

F)

Figura 28: Presença de C9 no citoplasma de fibroblastos observados por fluorescência. A), C) e E) Controle negativo: células do indivíduo normal (A), do paciente (C) e da mãe (E) marcadas somente com iodeto de propídio (vermelho) e anticorpo anti-IgG de cabra marcado com FITC (anticorpo secundário); B), D) e F) Células do indivíduo normal (B) do paciente (D) e da mãe (F) marcadas com iodeto de propídio (vermelho) e anticorpo policlonal anti-C9 humano feito em cabra (anticorpo primário). 


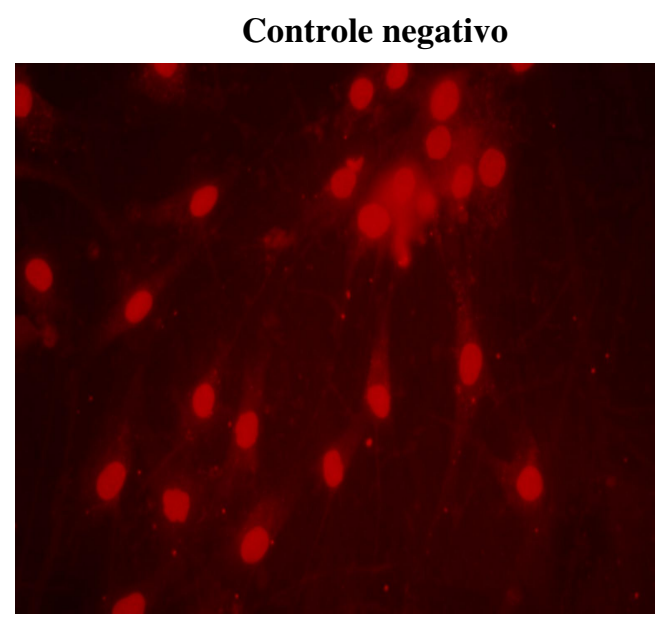

A)

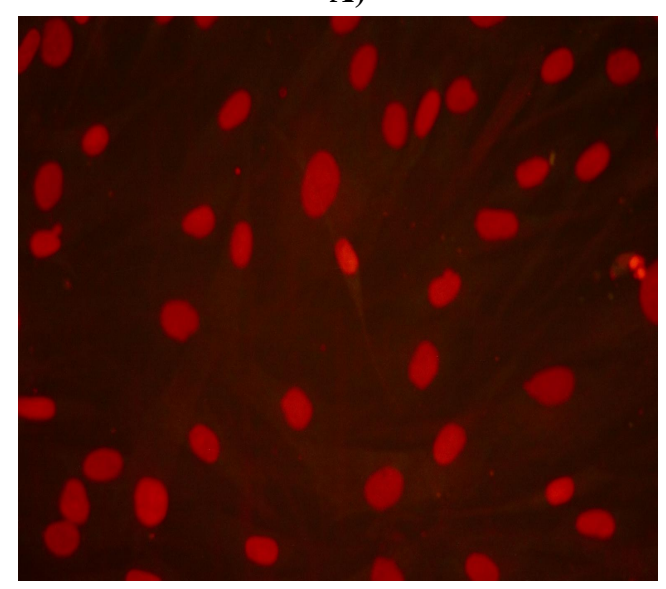

C)

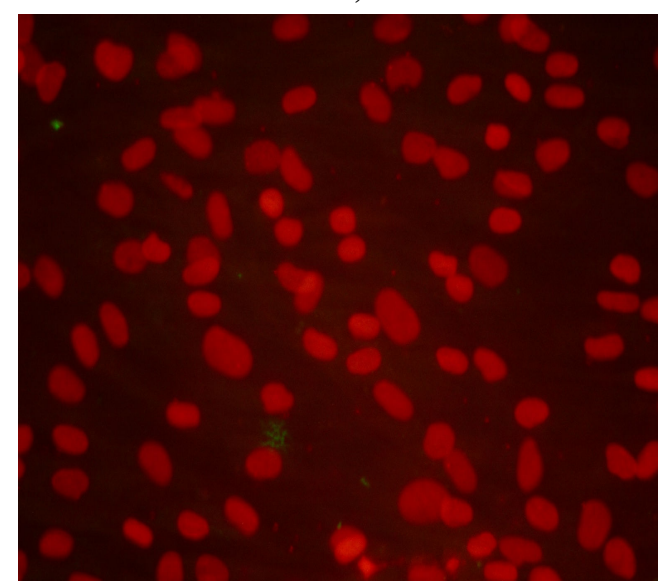

E)
C9

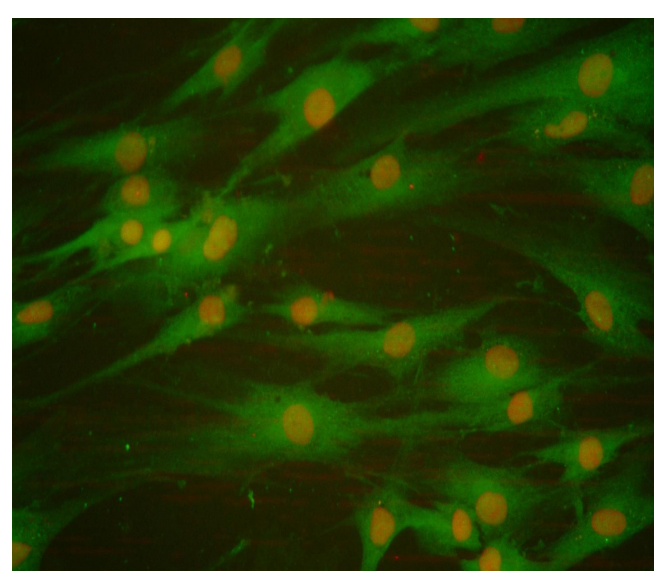

B)

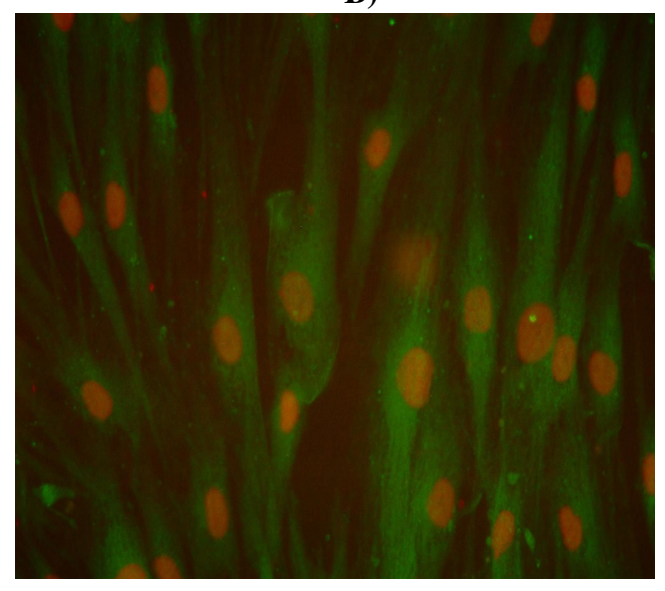

D)

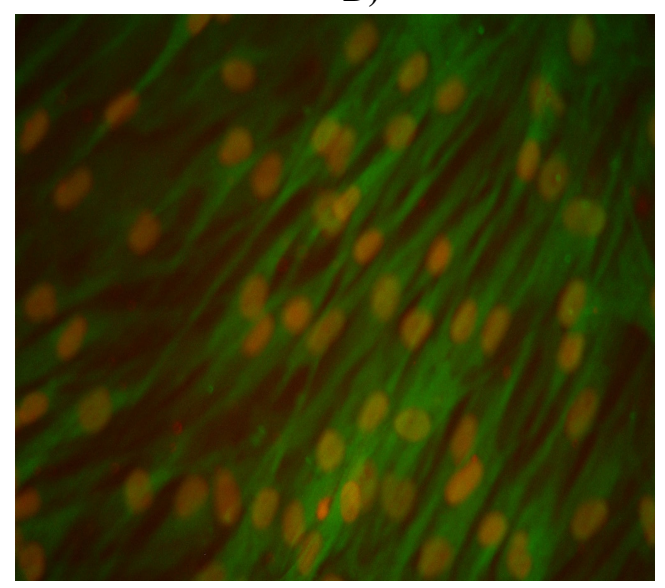

F)

Figura 29: Presença de C9 no citoplasma de fibroblastos observados por fluorescência. A), C) e E) Controle negativo: células do indivíduo normal (A), do pai (C) e da irmã do paciente (E) marcadas somente com iodeto de propídio (vermelho) e anticorpo anti-IgG de cabra marcado com FITC (anticorpo secundário); B), D) e F) Células do indivíduo normal (B) do pai (D) e da irmã do paciente (F) marcadas com iodeto de propídio (vermelho) e anticorpo policlonal antiC9 humano feito em cabra (anticorpo primário). 


\section{VI_DISCUSSÃO}

Deficiências genéticas de pelo menos 30 das proteínas do $\mathrm{C}$, incluindo efetoras e reguladoras, já foram descritas na literatura em associação com infecções graves ou com doenças auto-imunes (AULT et al, 1997).

Portadores da deficiência de C3 de forma primária ou secundária estão também diretamente relacionados com infecções recorrentes graves, como pneumonia, meningite, otite, tonsilite e sinusite, e a doenças mediadas pela deposição de complexos imunes, principalmente glomerulonefite (REIS et al, 2006).

Assim como os pacientes portadores de deficiência primária de $\mathrm{C} 3$, os pacientes com deficiência de FH também apresentam maior susceptibilidade a infecções por microorganismos infecciosos, como Streptococcus pneumoniae e Neisseria meningitidis, e a complicações renais em decorrência da deposição de complexos imunes, como lúpus, e da ativação desregulada do C, como glomerulonefrite e SHU. Os pacientes podem apresentar níveis plasmáticos de C3 variando entre indetectáveis e 50\% dos valores normais, além de níveis também reduzidos de FB, C5 e properdina, o que reflete o consumo excessivo das proteínas em virtude da ativação desregulada da via alternativa do C (REIS et al, 2006).

O paciente, um menino de 9 anos, desenvolveu dois episódios de pneumonia (um dos quais evoluiu para insuficiência respiratória) logo nos primeiros anos de vida, exigindo antibioticoterapia endovenosa, internação para drenagem torácica e tratamento na Unidade de Terapia Intensiva. Este quadro de infecções do trato respiratório está de acordo com o relatado para outros portadores da deficiência de FH (LEVY et al, 1986), embora exista muita variação sintomatológica entre eles, tendo sido relatados desde pacientes assintomáticos (THOMPSON \& WINTERBORN, 1981; BRAI et al, 1988; PICHETTE et al, 1994) a pacientes com infecções meningocócicas graves (LOPEZ-LARREA et al, 1987; NIELSEN et al, 1989; FIJEN et al, 1996) e/ou complicações renais por glomerulonefrite (LEVY et al, 
1986; LOPEZ-LARREA et al, 1987; DRAGON-DUREY et al, 2004) e síndrome hemolíticourêmica (THOMPSON \& WINTERBORN, 1981; PICHETTE et al, 1994; OHALI et al, 1998; ROUGIER et al, 1998).

Indivíduos portadores de deficiência do componente C9 são em geral assintomáticos. Entretanto, sabe-se que tais indivíduos têm um risco aumentado para o desenvolvimento de meningite meningocócica quando comparados aos não portadores dessa deficiência (KHAJOEE et al, 2003), quadro não observado no paciente estudado.

Tendo conhecimento de que indivíduos deficientes de proteínas do C são também portadores de diferentes níveis de comprometimento funcional desse sistema, nos pareceu adequado fazer do primeiro passo na caracterização da deficiência do paciente em questão a avaliação funcional dessas proteínas presentes no seu soro e no de seus familiares. Da mesma forma que o relatado para outros deficientes de FH (LEVY et al, 1986; BRAI et al, 1988; FIJEN et al, 1996), o soro do paciente estudado não foi capaz de provocar a lise de hemácias quer pela via clássica, quer pela alternativa. Já os soros do pai e irmã não apresentaram qualquer comprometimento funcional por qualquer das vias, enquanto que o soro da mãe apresentou funcionalidade da via alternativa abaixo da exibida por indivíduos normais. Essas diferenças nos graus de comprometimento funcional do $\mathrm{C}$ entre parentes de primeiro grau do paciente estão de acordo com os dados relatados na literatura (LEVY et al, 1986; BRAI et al, 1988; NIELSEN et al, 1989; PICHETTE et al, 1994; FIJEN et al, 1996), e acreditamos ser possivelmente equivalente ao nível de comprometimento de cada um com a mesma deficiência identificada no paciente.

Tendo confirmado o comprometimento funcional do $\mathrm{C}$ no paciente, decidimos avançar em direção à identificação da(s) proteína(s) ausente(s) no soro do paciente, através de métodos que nos fornecessem informações sobre as suas concentrações. O FH foi detectado no paciente em concentrações equivalentes a menos de $5 \%$ da encontrada em indivíduos 
normais, e estava associada com níveis indetectáveis de C3 e reduzidos de FB. Estes dados estão de acordo com os já relatados na literatura (LEVY et al, 1986; BRAI et al, 1988; NIELSEN et al, 1989; PICHETTE et al, 1994; FIJEN et al, 1996; ROUGIER et al, 1998; OHALI et al, 1998; DRAGON-DUREY et al, 2004), uma vez que a ausência da regulação da ativação da via alternativa do C provoca o consumo excessivo dessas proteínas. Vale ressaltar que, da mesma forma que no paciente, os níveis de C3 e FB estavam muito abaixo da faixa de normalidade também no soro de sua mãe, dado que concorda com o comprometimento funcional da via alternativa do C encontrado previamente no seu soro.

De forma oposta ao encontrado no soro do paciente e de sua mãe, níveis normais de C3 e FB foram encontrados no pai e irmã do paciente. Este dado, entretanto, não exclui uma deficiência parcial da proteína, uma vez que esses valores podem variar muito entre esses indivíduos (DRAGON-DUREY et al, 2004).

Até o momento, não temos conhecimento de relato na literatura de semelhante redução nos níveis de C3 e FB em apenas um dos pais do portador da deficiência de FH, principalmente enquanto os níveis séricos desse regulador apresentam-se muito acima do encontrado no indivíduo deficiente. Voltaremos a esta observação mais adiante nesta mesma seção.

A obtenção dos dados citados acima permitiu a identificação inicial do paciente estudado como sendo deficiente primário de $\mathrm{FH}$ e secundário do componente $\mathrm{C} 3$ em virtude da ausência deste regulador. Entretanto, através do Western Blot, pudemos confirmar a ausência de FH no soro do paciente e a sua presença nos soros de seus familiares. O FH detectado no soro dessa família exibiu aspectos estruturais semelhantes aos da proteína detectada no soro controle, entretanto, a sua presença no soro da mãe foi considerada como estando em níveis possivelmente menores do que os encontrados no soro controle ou mesmo 
nos demais membros da família. A utilização do método Western Blot para confirmação da deficiência do C nos pacientes foi usada por diferentes grupos (FIJEN et al, 1996; AULT et al, 1997; ROUGIER et al, 1998; SÁNCHEZ-CORRAL et al, 2000) e seus resultados estão de acordo com os relatados neste estudo, entretanto, nos trabalhos onde os soros dos pais do paciente foram avaliados adicionalmente (FIJEN et al, 1996; SÁBCHEZ-CORRAL et al, 2000) não houve menção à observação de concentrações possivelmente mais reduzidas em apenas um dos pais, quando comparada aos demais membros da família. Fato que também será novamente apreciado logo adiante.

Ainda através do Western Blot, pudemos detectar a ausência do FHL-1 no soro do paciente e sua presença no soro de seus pais e irmã. Pudemos observar também que outros membros da família FH, FHR-1 $\alpha$, FHR-1 $\beta$, estavam presentes tanto nos soros do paciente quanto no de seus familiares, contudo, aparentemente em maior concentração no soro da mãe, quando comparado aos demais membros da família ou mesmo ao soro controle. Este fato nos permite especular sobre a possibilidade de que a concentração aumentada de FH detectada no soro da mãe do paciente através do ELISA em comparação à encontrada no soro do paciente possa sofrer influência da presença em concentrações elevadas de outros membros da família FH. Assim, a concentração real de FH no soro da mãe seria consequentemente, menor do que a detectada pelo ELISA. A indisponibilidade em nosso laboratório de anticorpos capazes de detectar somente o FH não nos possibilitou investigar tal possibilidade.

Até o momento, apenas dois pacientes, cuja deficiência de FH comprometeu também a presença de FHL-1, foram relatados na literatura (SÁNCHEZ-CORRAL et al, 2001). Um outro grupo (AULT et al, 1997) havia mencionado previamente, através de ensaios com o Western Blot, a presença de FHL-1 no soro do paciente em concentrações acima da detectada em indivíduos normais, mas não sua ausência, como encontrada em nosso paciente. Vale ressaltar ainda que os estudos onde esse mesmo tipo de análise foi feito na tentativa de avaliar 
a família FH também nos soros dos parentes de primeiro grau do paciente (FIJEN et al, 1996; ROUGIER et al, 1998) foi detectado um perfil semelhante entre suas proteínas e as encontradas no soro controle, fato que contraria nossos resultados, uma vez que FHR-1 $\alpha$ e FHR-1 $\beta$ estão em concentrações possivelmente elevadas no soro da mãe.

Sabendo que o FHL-1 é composto pelos mesmos primeiros sete SCRs presentes no FH e que o FH concentra nesses SCRs sua habilidade de funcionar como co-fator na regulação do C (GORDON et al, 1995), não surpreende saber que o FHL-1 tem também a capacidade de atuar na regulação da via alternativa do C como co-fator e como acelerador da diminuição da atividade das C3 e C5 convertases (KUHN et al, 1995; KÜNH \& ZIPFEL, 1996). Assim pacientes deficientes de FH com adicional prejuízo na síntese de FHL-1 têm, consequientemente, ainda maiores dificuldades na realização da regulação da ativação da via alternativa do C.

As demais proteínas da família do FH encontradas no soro do paciente, FHR-1 $\alpha$ e FHR-1 $\beta$, não são associadas com a regulação da ativação da regulação do C. Entretanto, por serem antigenicamente relacionadas ao FH podem mascarar as concentrações residuais de FH detectadas nos soros dos indivíduos deficientes, bem como no de seus parentes de primeiro grau, dificultando seu diagnóstico acurado.

A partir de uma triagem semi-quantitativa das proteínas da via terminal do C, identificamos a deficiência do componente C9. Um novo Western Blot usando o soro do paciente e de seus familiares confirmou este dado pela identificação de concentrações muito reduzidas da proteína quando em comparação com o soro controle. Contudo, tanto a proteína encontrada no soro do paciente quanto às identificadas nos soros de seus familiares exibiram aspectos estruturais semelhantes aos da proteína encontrada num indivíduo normal. 
Análises de Western Blot de soros de pacientes deficientes de C9 já mostraram sua completa ausência no indivíduo afetado (HOBART et al, 1997). Entretanto indivíduos irlandeses relatados na literatura pela primeira vez por WITZEL-SCHLÖMP et al em 1998 (WITZEL-SCHLÖMP et al, 1998) e que tiveram o seu soro usado mais adiante nesse tipo de ensaio por ORREN et al em 2003 (ORREN et al, 2003) exibiram quantidades muito baixas de C9 no seu soro (determinadas através do ELISA), contudo, detectáveis em ensaios de Western Blot, da mesma forma que o paciente avaliado neste trabalho. Os autores procederam a uma análise funcional da proteína encontrada de forma residual no soro e observaram uma capacidade de lisar bactérias e de se incorporar ao MAC em níveis similares aos exibidos por indivíduos normais, dados não avaliados em nosso paciente.

Ao tentar determinar a concentração exata do C9 residual no soro do paciente e de seus familiares encontramos repetidas vezes concentrações abaixo das consideradas como referência - $58 \pm 8 \mu \mathrm{g} / \mathrm{ml}$ (BIESECKER \& MÜLLER-EBERHARD, 1980; KAWACHITAKAHASHI et al, 1975) - na mistura de soros de indivíduos normais. Entretanto, FERREIRA DE PAULA et al (2003) encontraram previamente discrepâncias entre valores relatados como referência na literatura para o FI $(35 \mu \mathrm{g} / \mathrm{ml})$ e os encontrados na população brasileira $(66,4 \mu \mathrm{g} / \mathrm{ml})$ (FERREIRA DE PAULA et al, 2003). Diante destas informações e das concentrações de C9 por nós detectadas em 31 indivíduos normais não relacionados, somos levados a sugerir que diferenças inerentes a cada etnia podem influenciar diretamente no nível plasmático das proteínas do $\mathrm{C}$ e, por conseguinte, o nível de $\mathrm{C} 9$ na população brasileira é inferior ao já detectado em outras populações.

Existe apenas um registro prévio na literatura de deficiência completa da proteína reguladora FH combinada com a de um outro componente do C. Em 1988, BRAI et al (BRAI et al, 1988), identificaram um paciente com menos de $1 \%$ dos níveis de $\mathrm{FH}$ encontrados num indivíduo normal e níveis do componente C2 equivalentes a $20 \%$ do limite inferior da faixa de 
referência para este componente (75\% a 120\%). Todavia, a deficiência combinada entre o regulador $\mathrm{FH}$ e o componente $\mathrm{C}$, encontrada em nosso paciente, não tem precedentes na literatura.

Para iniciarmos a análise das bases moleculares das deficiências do $\mathrm{C}$ encontradas no paciente estudado, avaliamos a expressão de RNAm de FH do paciente em comparação com o indivíduo normal pela amplificação de diferentes fragmentos de seu cDNA. Como não foram identificadas diferenças de tamanho ou intensidade entres os fragmentos obtidos do paciente e os do controle normal, como encontrado em outros pacientes previamente estudados pelo nosso grupo (ULBRICH et al, 2001 [deficiente de C3]; BARACHO et al, 2003 [deficiente de FI]), pudemos considerar como improváveis a existência de códons de parada prematura ou mesmo grandes inserções e deleções no DNA do paciente. A escassez de informações semelhantes relativas aos deficientes de FH não nos permitiu fazer este mesmo tipo de comparação entre os dados obtidos de nosso paciente e os demais deficientes de FH relatados na literatura.

O seqüenciamento desses fragmentos de cDNA revelou que o paciente era portador de três mutações diferentes no gene $F H$. A primeira delas, G453A, localizada no éxon 4 do SCR2 leva à substituição de uma Arg por uma His na posição 127. DRAGON-DUREY et al (2004) relataram a existência de uma mutação similar na mesma posição, G453T, substituindo a $\operatorname{Arg}^{127}$ por uma Leu ${ }^{127}$. Os pacientes em questão exibiram níveis de $\mathrm{FH}$ abaixo de $1 \%$ do valor de referência e níveis também muito reduzidos de C3 e FB, dados semelhantes aos encontrados no nosso paciente. Os autores atribuíram a esta mutação a responsabilidade pela deficiência de FH encontrada nos pacientes avaliados e ainda observaram que dos 16 pacientes avaliados, entre homozigotos e heterozigotos, 4 tiveram mutações envolvendo uma Arg. Informações não publicadas deste mesmo grupo relatam que esta mutação não foi encontrada em qualquer dos 400 alelos avaliados de 200 indivíduos normais. 
Apesar dos resultados encontrados em nosso paciente concordarem com os relatados na literatura, a identificação da mesma mutação no gene $F H$ da mãe também na forma homozigota, uma vez que ela possui a proteína de $150 \mathrm{kDa}$ (Western Blot ) no seu soro, nos levou a questionar a relevância desta mutação sobre a deficiência encontrada no paciente avaliado neste estudo. Somos levados a considerar que fatores adicionais presentes na mãe, talvez associados à idade, e não no paciente devem influenciar concomitantemente os níveis de FH presentes no seu soro. Apesar de esses fatores serem ainda por nós desconhecidos, vale lembrar que os níveis de FH encontrados no soro da mãe (ELISA) em concentrações tão acima das evidenciadas no soro do paciente podem sofrer influência dos níveis aumentados de outros membros da família FH. Este fenômeno impossibilitaria a identificação acurada de seus níveis reduzidos de FH e que seriam condizentes com os níveis também muito reduzidos de $\mathrm{C} 3$ e FB, adicionalmente encontrados.

Ainda falando a favor da importância desta mutação para a deficiência de FH encontrada no paciente, temos conhecimento de que a $\operatorname{Arg}^{127}$ é filogeneticamente muito conservada na estrutura do FH (Quadro 3), além de estar a apenas um aminoácido da Cys ${ }^{129}$ (SAUNDERS et al, 2006) diretamente envolvida em uma das pontes dissulfídicas essenciais para a formação da estrutura terciária dos SCRs e, neste caso, do SCR-2. A importância desta localização fica ainda mais evidente quando lembramos que o grupo americano (AULT et al, 1997; SCHMIDT et al, 1999) identificou e estudou duas mutações que levavam à substituição de dois resíduos de Cys $\left(\mathrm{Cys}^{518}\right.$ e Cys $\left.{ }^{991}\right)$ por outros aa nos SCRs -9 e -16, respectivamente. Eles demonstraram que os fibroblastos do paciente eram capazes de produzir, mas não de secretar o FH e que proteínas mutantes carregando estas mutações eram expressas na célula e ficavam retidas no retículo endoplasmático. Assim, podemos sugerir que modificações de aminoácidos localizados tão próximos a resíduos de Cys possam desestabilizar a estrutura das 
pontes dissulfídicas e, consequëntemente, sua estrutura terciária, a ponto de impedir sua secreção para o meio externo à célula.

Quadro 3: Alinhamento do FH entre espécies.

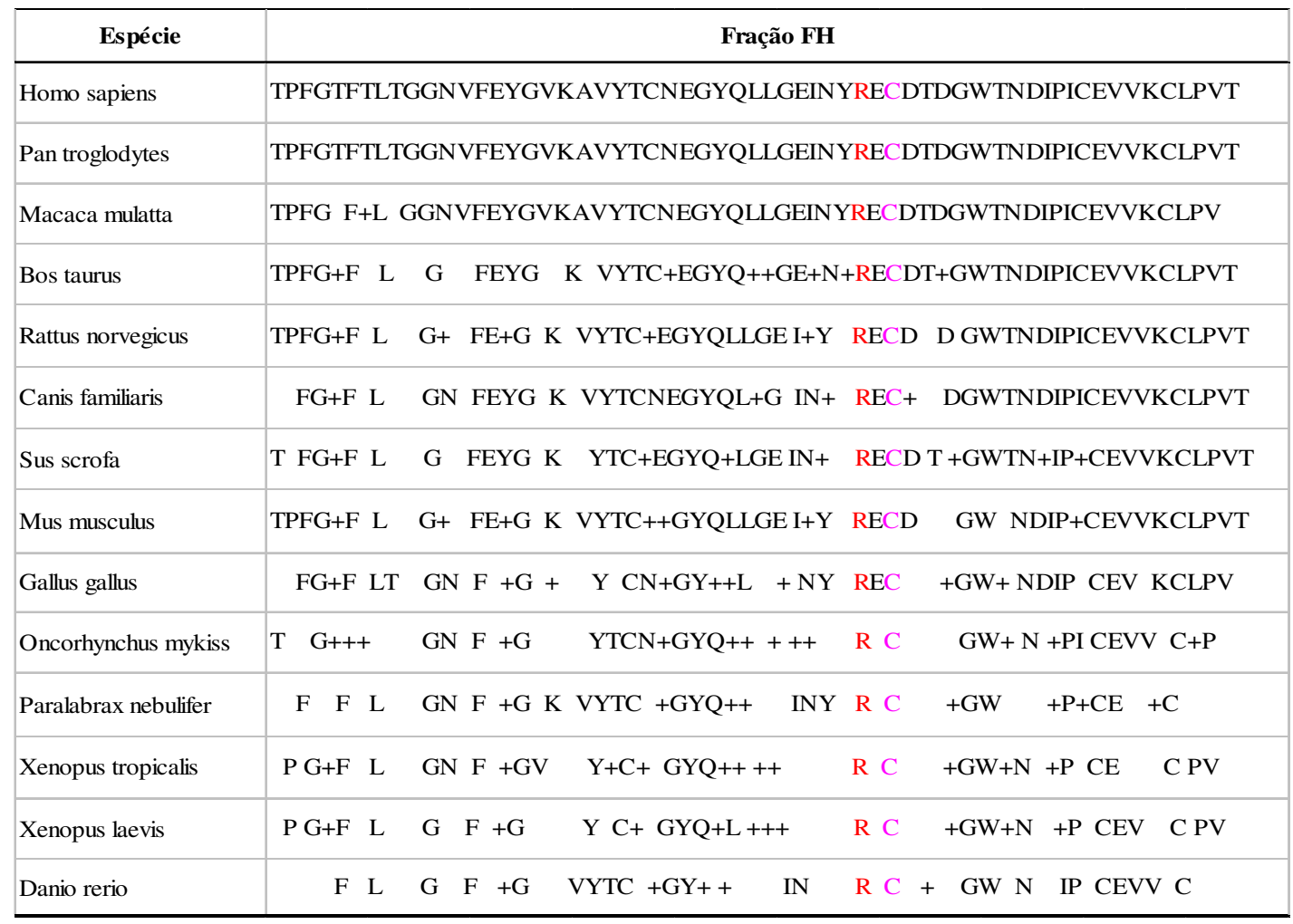

Adicionalmente, a $\operatorname{Arg}^{127}$ é um aminoácido hidrofílico grande, básico e que fica exposto na estrutura secundária da proteína. Sua substituição por uma His, ainda que também seja um aminoácido grande, básico e hidrofílico, não é um fenômeno conservado e pode causar danos estruturais à proteína e, conseqüentemente à sua habilidade de deslocamento do citoplasma para o meio extracelular (www.fh-hus.org.br).

A fim de avaliar o perfil de secreção de FH pelas células do paciente, nós cultivamos seus fibroblastos e os de um indivíduo normal sob diferentes tempos de estímulo com o IFN $\gamma$, uma vez que KATZ \& STRUNK (1988) já haviam demonstrado que esta citocina aumenta a expressão de transcritos de RNAm de FH pelas células de indivíduos normais. Assim, da mesma forma que AULT et al (1997) nós coletamos os sobrenadantes e lisados celulares 
dessas culturas e os utilizamos em ensaios de Western Blot (resultado não mostrado). Aparentemente, já a partir de 24 h pós-estímulo os fibroblastos do indivíduo normal foram capazes de secretar FH no sobrenadante, ao contrário dos fibroblastos do paciente que, mesmo após 48 h de estímulo só foram capazes de exibir a presença de FH no meio intracelular. Este resultado está de acordo com os relatados na literatura e reforçou a nossa hipótese de que problemas estruturais na proteína surgidos em virtude da presença da mutação estariam impedindo a secreção de $\mathrm{FH}$ pelas células do paciente. Contudo, o sinal referente à presença desta proteína tanto no indivíduo normal quanto no paciente teve intensidade muito baixa, seja por uma limitação da técnica, seja pela presença de $\mathrm{FH}$ em concentrações muito reduzidas, e nos impediu de afirmar a veracidade deste resultado e, ainda, confirmar categoricamente a nossa teoria.

Assim, ainda com essa hipótese em mente, procedemos, então, à avaliação da presença de FH no citoplasma de fibroblastos do paciente em comparação com o indivíduo normal, utilizando a microscopia confocal. Do mesmo modo que nos fibroblastos do paciente estudado por AULT et al (1997), pudemos identificar a presença de FH retido no espaço intracelular dos fibroblastos do paciente avaliado neste estudo, até mesmo em concentrações possivelmente mais elevadas do que no indivíduo normal. Este resultado nos permite sugerir que as células do paciente são capazes de produzir e expressar este regulador, entretanto, as modificações estruturais geradas na proteína em virtude da presença da mutação impedem a sua correta secreção a partir de tais células. Vale ressaltar que, uma vez que a mutação está localizada no SCR-2 do FH, presente também no FHL-1, a mesma mutação justifica a ausência das duas proteínas. Contudo, ao avaliarmos a marcação relativa à presença de FH nos fibroblastos da mãe, percebemos que a marcação tinha intensidade menor do que a detectada nas células de um indivíduo normal. Esta informação nos pareceu, a princípio, surpreendente, entretanto ao compararmos este dado com as concentrações deste regulador 
medidas no seu soro através do método ELISA ou mesmo a presença da banda de $150 \mathrm{kDa}$ (FH) observada pelo método Western Blot, fomos levados a constatar que, na verdade, o resultado era condizente com os obtidos previamente. Assim, uma vez que o FH está presente em concentrações reduzidas no seu soro, a marcação menos intensa é condizente com uma menor produção desta proteína. Adicionalmente, a presença da banda de $150 \mathrm{kDa}$ no soro da mãe indica não só que esta proteína está sendo produzida pelas suas células como também está sendo secretada. Uma vez secretada, a proteína não ficaria, provavelmente, retida no citoplasma e a marcação não seria mais intensa do que a detectada no indivíduo normal, como foi observado para o paciente. Diante de todas essas informações somos mais uma vez levados a crer que fatores adicionais presentes na mãe, mas não no paciente possivelmente tornam possível a secreção de FH apesar da presença da mutação.

A existência em nosso laboratório de uma outra família de deficientes, desta vez de C5, na qual um dos pais, apesar de homozigoto para a mutação detectada no paciente, é capaz de produzir este componente em concentrações mais elevadas do que o esperado, leva-nos a cogitar a possibilidade de que, passada a infância, os sistemas de alguns indivíduos deficientes providenciem meios de compensação para a deficiência.

Duas outras mutações foram também encontradas no gene $F H$ do paciente, entretanto, por serem polimorfismos previamente descritos na literatura (MANUELIAM et al, 2003; NEUMANN et al, 2003) acreditamos que não determinem alterações na estrutura do FH.

Por fim, o seqüenciamento dos éxons do gene $C 9$ (e de suas respectivas porções íntron/éxon) do paciente revelou a ausência da mutação na $\operatorname{Arg}^{95}$ responsabilizada pela deficiência deste componente na população japonesa (HORIUCHI et al, 1998; KIRA et al, 1999), da qual nosso paciente é descendente. Foram detectados também polimorfirmos previamente descritos na literatura (WITZEL-SCHLÖMP et al, 1998; WITZEL-SCHLÖMP 
et al, 2001). Contudo, não pudemos identificar qualquer mutação que pudesse justificar a deficiência a deficiência deste componente no soro do paciente.

Entretanto, a presença de uma marcação menos intensa relativa à presença de C9 nos fibroblastos do paciente confirma mais uma vez a existência neste indivíduo de alterações ainda por nós desconhecidas que comprometem a produção deste componente pelas suas células, sem, entretanto, prejudicar sua secreção, uma vez que este componente é encontrado no soro do paciente. A marcação detectada de forma semelhante à do indivíduo normal nos demais membros da família e a detecção de concentrações normais deste componente nestes indivíduos levam-nos, ainda, a suspeitar que as alterações envolvidas no prejuízo da produção de C9 pelas células do paciente estão, possivelmente, presentes apenas nele, mas não nos demais membros da família. 


\section{VII_CONCLUSÕES}

$\Rightarrow \mathrm{O}$ paciente é portador de deficiência primária da proteína reguladora $\mathrm{FH}$ em concomitância com a deficiência do componente C9.

$\Rightarrow$ Não foi possível avaliar aspectos estruturais do FH no soro do paciente, uma vez que esta proteína estava completamente ausente. O FHL-1 também estava ausente, entretanto outros membros da família FH, FHR-1 $\alpha$ e FHR-1 $\beta$, estavam presentes e exibiram aspectos estruturais gerais semelhantes aos encontrados no soro controle.

$\Rightarrow \mathrm{O}$ componente $\mathrm{C} 9$ encontrado em níveis residuais no soro do paciente exibiu peso molecular e perfil eletroforético semelhantes aos exibidos pelo C9 encontrado no soro controle.

$\Rightarrow$ Uma substituição G453A encontrada no éxon 4 do SCR-2 do gene $F H$ do paciente é a provável responsável pela sua deficiência de FH. Uma vez que a mutação está localizada no SCR-2 ela é, possivelmente, também a causa da ausência associada do FHL-1.

$\Rightarrow$ A mesma mutação foi encontrada, também de forma homozigota, no DNA genômico da mãe do paciente, mas de forma heterozigota no DNA do pai e irmã, confirmando a possibilidade do padrão de herança autossômico recessivo para a deficiência de FH no indivíduo analisado. 
$\Rightarrow$ Não foi detectada a presença de mutações no gene $C 9$ do paciente que pudessem ser responsabilizadas pela deficiência de C9 neste indivíduo.

$\Rightarrow$ Juntos, os resultados revelam a identificação e caracterização do primeiro caso de deficiência completa da proteína reguladora FH na população brasileira e, até onde temos conhecimento, o primeiro relato de deficiência concomitante deste regulador e do componente C9. 


\section{VIII_REFERÊNCIAS BIBLIOGRÁFICAS}

ALPER, C. A. (1986/1987). Inherited deficiencies of complement components in man. Immunolog Letters, 14: 175-181.

ALTSCHUL, S. F., MADDEN, T. L., SCHAFFER, A. A., ZHANG, J., ZHANG, Z., MILLER, W., LIPMAN, D. J. (1997). Gapped BLAST and PSI-BLAST: a new generation of protein database search programs. Nucleic Acids Res, 25(17): 3389-402.

AMADEI, N., BARACHO, G. V., NUDELMAN, V., BASTOS, W., FLORIDO, M. P., ISAAC, L. (2001).Inherited complete factor I deficiency associated with systemic lupus erythematosus, higher susceptibility to infection and low levels of factor H. Scand J Immunol, 53(6): 615-21.

ARLAUD, G. J., VOLANAKIS, J. E., THIELENS, N. M., NARAYANA, S. V., ROSSI, V., XU, Y. (1998). The atypical serine proteases of the complement system. Adv Immunol, 69: 249-307.

ASGHAR, S. S., VENNEKER, G. T., VAN MEEGEN, M., MEINARDI, M. M., HULSMANS, R. F., DE WAAL, L. P. (1991).Hereditary deficiency of C5 in association with discoid lupus erythematosus. J Am Acad Dermatol, 24(2): 376-8.

ATKINSON, J. P., LISZEWSKI, M. K., RICHARDS, A., KAVANAGH, D., MOULTON, E. A. (2005). Hemolytic uremic syndrome: an example of insufficient complement regulation on self-tissue. Ann N Y Acad Sci, 1056: 144-52.

AULT, B. H., SCHMIDT, B. Z., FOWLER, N. L., KASHTAN, C. E., AHMED, A. E., VOGT, B. A., COLTEN, H. R. (1997). Human factor H deficiency. Mutations in framework cysteine residues and block in H protein secretion and intracellular catabolism. J Biol Chem, 272(40): 25168-25175.

BARACHO, G. V., NUDELMAN, V., ISAAC, L. (2003).Molecular characterization of homozygous hereditary factor I deficiency. Clin Exp Immunol, 131(2): 280-6.

BARBA, G., RITTNER, C., SCHNEIDER, P. M. (1993). Genetic basis of human complement C4A deficiency. Detection of a point mutation leading to nonexpression. J Clin Invest, 91(4): 1681-6.

BIESECKER, G., MÜLLER-EBERHARD, H. J. (1980). The ninth component of human complement: purification and physicochemical characterization. J Immunol, 124(3): 1291-1296.

BLACKMORE, T. K., SADLON, T. A., WARD, H. M., LUBLIN, D. M., GORDON, D. L. (1996). Identification of a heparin binding domain in the seventh short consensus repeat of complement factor H. J Immunol, 157(12): 5422-5427. 
BLACKMORE, T. K., HELlWAGE, J., SADLON, T. A., HIGGS, N., ZIPFEL, P. F., WARD, H. M., GORDON, D. L. (1998). Identification of the second heparin-binding domain in human complement factor H. J Immunol, 160(7): 3342-3348.

BLOM, A. M. (2002).Structural and functional studies of complement inhibitor C4b-binding protein. Biochem Soc Trans, 30(6): 978-82.

BLOM, A. M., VILLOUTREIX, B. O., DAHLBACK, B. (2004). Functions of human complement inhibitor C4b-binding protein in relation to its structure. Arch Immunol Ther Exp, 52(2): 83-95.

BOS, I. G., HACK, C. E., ABRAHAMS, J. P. (2002). Structural and functional aspects of C1inhibitor. Immunobiology, 205(4-5): 518-33.

BRAI, M., MISIANO, G., MARINGHINI, S., CUTAJA, I., HAUPTMANN, G. (1988). Combined homozygous factor $\mathrm{H}$ and heterozygous $\mathrm{C} 2$ deficiency in an Italian family. J Clin Immunol, 8(1): 506.

CAPRIOLI, J., BETTINAGLiO, P., ZIPFEL, P. F., AMADEI, B., DAINA, E., GAMBÁ, S., SKERKA, C., MARZILIANO, N., REMUZZI, G., NORIS, M. Italian Registry of Familial and Recurrent HUS/TTP. (2001). The molecular basis of familial hemolytic uremic syndrome: mutation analysis of factor H gene reveals a hot spot in short consensus repeat 20. J Am Soc Nephrol, 12(2): 297-307.

CAPRIOLI, J., CASTELLETTI, F., BUCCHIONI, S., BETTINAGLIO, P., BRESIN, E., PIANETTI, G., GAMBA, S., BRIOSCHI, S., DAINA, E., REMUZZI, G., NORIS, M. International Registry of Recurrent and Familial HUS/TTP. (2003). Complement factor $\mathrm{H}$ mutations and gene polymorphisms in haemolytic uraemic syndrome: the C-257T, the A2089G and the G2881T polymorphisms are strongly associated with the disease. Hum Mol Genet, 12(24): 3385-3395.

CHIRGWIN, J. M., PRZYBYLA, A. E., MACDONAL, R. J., RUTTER, W. J. Isolation of biologically active ribonucleic acid from sources enriched in ribonuclease. Biochemistry, 18(24): $5294-5349$.

CICARDI, M., ZINGALE, L., ZANICHELli, A., PAPPALARDO, E., CICARDI, B. (2005). C1 inhibitor: molecular and clinical aspects. Springer Semin Immunopathol, 27(3): 286-98.

COLE, J. L., HOUSLEY, G. A. JR., DYKMAN, T. R., MACDERMOTT, R. P., ATKINSON, J. P. (1985). Identification of an additional class of C3-binding membrane proteins of human peripheral blood leukocytes and cell lines. Proc Natl Acad Sci U S A, 82(3): 859-63. 
COLTEN, H. R. \& ROSEN, F. S. (1992). Complement deficiencies. Annual Review of Immunology, 34(10): 809-834.

CONLEY, Y.P.; THALAMUTHU, A.; JAKOBSDOTTIR, J.; WEEKS, D.E.; MAH, T.; FERREL, RE.; GORIN, M.B. (2005). Candidate gene analysis suggests a role for fatty acid biosynrhesis and regulation of the complement system in the etiology of age-related maculopathy. Hum. Molecular

Genetics, 14: 1991-2002.

DAHA, M. R., FEARON, D. T., AUSTEN, K. F. (1976). C3 nephritic factor (C3NeF): stabilization of fluid phase and cell-bound alternative pathway convertase. J Immunol, 116(1): 1-7.

DAHL, M. R., THIEL, S., MATSUSHITA, M., FUJITA, T., WILLIS, A. C., CHRISTENSEN, T., VORUP-JENSEN, T., JENSENIUS, J. C. (2001). MASP-3 and its association with distinct complexes of the mannan-binding lectin complement activation pathway. Immunity, 15(1): 127-35.

DAVITZ, M. A. (1987). Decay-accelerating factor (DAF): a review of its function and structure. Acta Med Scand Suppl, 715: 111-21.

DISCIPIO, R. G., GEHRING, M. R., PODACK, E. R., KAN, C. C., HUGLI, T. E., FEY, G. H. (1984). Nucleotide sequence of cDNA and derived amino acid sequence of human complement component C9. Proc Natl Acad Sci U S A, 81(23): 7298-302.

DISCIPIO, R. G. (1992). Ultrastructures and interactions of complement factors H and I. J Immunol, 149(8): 2592-9.

DISCIPIO, R. G., BERLIN, C. (1999). The architectural transition of human complement component C9 to poly(C9). Mol Immunol, 36(9): 575-85.

DRAGON-DUREY, M. A., FREMEAUX-BACCHI, V., LOIRAT, C., BLOUIN, J., NIAUDET, P., DESCHENES, G., COPPO, P., HERMAN FRIDMAN, W., WEISS, L. (2004). Heterozygous and homozygous factor $\mathrm{h}$ deficiencies associated with hemolytic uremic syndrome or membranoproliferative glomerulonephritis: report and genetic analysis of 16 cases. J Am Soc Nephrol, 15(3): 787-95.

DRAGON-DUREY, M. A., FREMEAUX-BACCHI, V. (2005). Atypical haemolytic uraemic syndrome and mutations in complement regulator genes. Springer Semin Immunopathol, 27(3): $359-74$.

ESPARZA-GORDILLO, J., GOICOECHEA DE JORGE, E., BUIL, A., CARRERAS BERGES, L., LOPEZ-TRASCASA, M., SANCHEZ-CORRAL, P., RODRIGUEZ DE CORDOBA, S. (2005). 
Predisposition to atypical hemolytic uremic syndrome involves the concurrence of different susceptibility alleles in the regulators of complement activation gene cluster in 1q32. Hum Mol Genet, 14(5): 703-712.

EDWARDS, A.O.; RITTER III, R.; ABEL, K.J.; MANNING, A.; PANHUYSEN, C. \& FARRER, L.A. (2005). Complement Factor H polymorphism and age-related macular degeneration. Sciences, 308: 421-424.

ESPARZA-GORDILlO, J., JORGE, E. G., GARRIDO, C. A., CARRERAS, L., LOPEZTRASCASA, M., SANCHEZ-CORRAL, P., DE CORDOBA, S. R. (2006). Insights into hemolytic uremic syndrome: segregation of three independent predisposition factors in a large, multiple affected pedigree. Mol Immunol, 43(11): 1769-75.

ESTALLER, C., SCHWAEBLE, W., DIERICH, M., WEISS, E. H. (1991). Human complement factor $\mathrm{H}$ : two factor $\mathrm{H}$ proteins are derived from alternatively spliced transcripts. European Journal of Immunology, 21: 799-802.

FARKAS, I., BARANYI, L., ISHIKAWA, Y., OKADA, N., BOHATA, C., BUDAI, D., FUKUDA, A., IMAI, M., OKADA, H. (2002). CD59 blocks not only the insertion of C9 into MAC but inhibits ion channel formation by homologous C5b-8 as well as C5b-9. J Physiol, 539(2): 537-45.

FEARON, D. T., LOCKSLEY, R. M. (1996). The instructive role of innate immunity in the acquired immune response. Science, 272(5258): 50-3.

FERREIRA DE PAULA, P., BARBOSA, J. E., JUNIOR, P. R., FERRIANI, V. P., LATORRE, M. R., NUDELMAN, V., ISAAC, L. (2003). Ontogeny of complement regulatory proteins - concentrations of factor $\mathrm{h}$, factor I, c4b-binding protein, properdin and vitronectin in healthy children of different ages and in adults. Scand J Immunol, 58(5): 572-7.

FERRIANI, V. P. L., BARBORA, J. E., AND CARVALHO, I. F. (1999). Complement haemolytic (classical and alternative pathways), C3, C4 and factor B titres in healthy children. Acta Paediatr, 88: 1062-1066.

FIJEN, C. A., KUIJPER, E. J., TE BULTE, M., VAN DE HEUVEL, M. M., HOLDRINET, A. C., SIM, R. B., DAHA, M. R., DANKERT, J. (1996). Heterozygous and homozygous factor H deficiency states in a Dutch family. Clin Exp Immunol, 105(3): 511-6.

FIJEN, C. A., VAN DEN BOGAARD, R., SCHIPPER, M., MANNENS, M., SCHLESINGER, M., NORDIN, F. G., DANKERT, J., DAHA, M. R., SJOHOLM, A. G., TRUEDSSON, L., KUIJPER, E. 
J. (1999). Properdin deficiency: molecular basis and disease association. Mol Immunol, 36(13-14): 863-867.

FISHELSON, Z., KOZER, E., SIRHAN, S., KATZ, Y. (1999). Distinction between processing of normal and mutant complement C3 within human skin fibroblasts. Eur J Immunol, 29(3): 845-55.

FRIESE, M. A., HellwaGe, J., JOKIRANTA, T. S., MERI, S., PETER, H. H., EIBEL, H., ZIPFEL, P. F. (1999). FHL-1/reconectin and factor H: two human complement regulators which are encoded by the same gene are differently expressed and regulated. Mol Immunol, 36(13-14): 809818.

FUJITA, T. (2002). Evolution of the lectin-complement pathway and its role in innate immunity. Nat Rev Immunol, 2(5): 346-353.

FUJITA, T., MATSUSHITA, M., ENDO, Y. (2004). The lectin-complement pathway--its role in innate immunity and evolution. Immunol Ver, 198: 185-202.

GENEL, F., SJOHOLM, A. G., SKATTUM, L., TRUEDSSON, L. (2005). Complement factor I deficiency associated with recurrent infections, vasculitis and immune complex glomerulonephritis. Scand J Infect Dis, 37(8): 615-618.

GERARD, C., HUGLI, T. E. (1981). Identification of classical anaphylatoxin as the des-Arg form of the C5a molecule: evidence of a modulator role for the oligosaccharide unit in human des-Arg74-C5a. Proc Natl Acad Sci U S A, 78(3): 1833-1837.

GIANNAKIS, E., MALE, D. A., ORMSBY, R. J., MOLD, C., JOKIRANTA, T. S., RANGANATHAN, S., GORDON, D. L. (2001). Multiple ligand binding sites on domain seven of human complement factor H. Int Immunopharmacol, 1(3): 433-443.

GOMPELS, M. M., LOCK, R. J. (2005). C1 inhibitor deficiency: diagnosis. Clin Exp Dermatol, 30(4): 460-2.

GORDON, D. L., KAUFMAN, R. M., BLACKMORE, T. K., KWONG, J., LUBLIN, D. M. (1995). Identification of complement regulatory domains in human factor H. J Immunol, 155(1): 348-356.

HAGEMAN, G.S.; ANDERSON, D.H.; JOHNSON, L.V.; HANCOX, L.S., TAIBER, A.J.; HARDISTY, L.I.; HAGEMAN, J.L.; STOCKMAN, H.A.; BORCHARDT, J.D.; GEHRS, K.M.; SMITH, R.J., SILVESTRI, G.; RUSSELL, S.R.; KLAVER, CC; BARBAZETTO, I.; CHANG, S.; YANUZZI, L.A.; BARILE, G.R.; MERRIAM, J.C.; SMITH, RT.; OLSH, A.K.; BERGERON, J.; ZERNANT, J.; MERRIAM, J.E.; GOLD, B.; DEAN, M.; ALLIKMETS, R. (2005). A commom 
haplotype in the complement regulatory gene factor $\mathrm{H}(\mathrm{HF} 1 / \mathrm{CFH})$ predisposes individuals to agerelated macular degeneration. Proc. Natl. Acad Sci USA, 102: 7227-7232.

HAINES, J.L.; HAUSER, M.A.; SCHMIDT, S.; SCOTT, W.K.; OLSON, L.M.; GALLINS, P.; SPENCER, K.L. KWAN, S.Y.; NOUREDDINE, M.; GILBERT, J.R.; SCHNETZ-BOUTAUD.; AGARWAL, A.; POSTEL, E.A.; PERICAK-VANCE, M.A. (2005). Complement factor H variant increases the risk of age-related macular degeneration. Sciences, 308: 419-421.

HEGASY, G. A., MANUELIAN, T., HOGASEN. K., JANSEN, J. H., ZIPFEL, PF. (2002). The molecular basis for hereditary porcine membranoproliferative glomerulonephritis type II: point mutations in the factor H coding sequence block protein secretion. Am J Pathol, 161(6): 2027-2034.

HIEMSTRA, P. S., LANGELER, E., COMPIER, B., BEEPERS, Y., LEIJH, P. C., VAN DEN BARSELAAR, M. T., OVERBOSCH, D., DAHA, M. R. (1989). Complete and partial deficiencies of complement factor D in a Dutch family. J Clin Invest, 84(6): 1957-1961.

HOBART, M. J., FERNIE, B. A., WURZNER, R., OLDROYD, R. G., HARRISON, R. A., JOYSEY, V., LACHMANN, P. J. (1997). Difficulties in the ascertainment of C9 deficiency: lessons to be drawn from a compound heterozygote C9-deficient subject. Clin Exp Immunol, 108(3): 500-6.

HOURCADE, D., LISZEWSKI, M. K., KRYCH-GOLDBERG, M., ATKINSON, J. P. (2000). Functional domains, structural variations and pathogen interactions of MCP, DAF and CR1. Immunopharmacology, 49(1-2): 103-116.

HORIUCHI, T., NISHIZAKA, H., KOJIMA, T., SAWABE, T., NIHO, Y., SCHNEIDER, P. M., INABA, S., SAKAI, K., HAYASHI, K., HASHIMURA, C., FUKUMORI Y. (1998). A non-sense mutation at Arg95 is predominant in complement 9 deficiency in Japanese. J Immunol, 160(3): 150913.

ICHIKAWA, E., FURUTA, J., KAWACHI, Y., IMAKADO, S., OTSUKA, F. (2001). Hereditary complement (C9) deficiency associated with dermatomyositis. Br J Dermatol, 144(5): 1080-3.

IKEDA, K., SANNOH, T., KAWASAKI, N., KAWASAKI, T., YAMASHINA, I. (1987). Serum lectin with known structure activates complement through the classical pathway. J Biol Chem, 262: 7451-7454. 
JAMES, K. (1982). Complement: Activation, consequences, and control. American Journal of

Medical Technology, 48(9): 735-742.

JARVA, H., JOKIRANTA, T. S., HELLWAGE, J., ZIPFEL, P. F., MERI, S. (1999). Regulation of complement activation by C-reactive protein: targeting the complement inhibitory activity of factor $\mathrm{H}$ by an interaction with short consensus repeat domains 7 and 8-11. J Immunol, 163(7): 3957-3962.

JOZSI, M., MANUELIAN, T., HEINEN, S., OPPERMANN, M., ZIPFEL, P. F. (2004). Attachment of the soluble complement regulator factor $\mathrm{H}$ to cell and tissue surfaces: relevance for pathology. Histol Histopathol, 19(1): 251-8.

KAPLAN, B. S., CHESNEY, R. W., DRUMMOND, K. N. (1975). Hemolytic uremic syndrome in families. N Engl J Med, 292: 1090-1093.

KATZ, Y., STRUNK, R. C. (1988). Synthesis and regulation of complement protein factor H in human skin fibroblasts. J Immunol, 141(2): 559-563.

KAWACHI-TAKAHASHI, S., TANAKA, K., TAKAHASHI, M., KAWASHIMA, T., SHIMADA, K. (1975). Determination of serum C9 level by immunodiffusion. Elevation in patients with infectious or allergic skin diseases. Int Arch Allergy Appl Immunol, 48(2): 161-70.

KEMPER, C., CHAN, A. C., GREEN, J. M., BRETT, K. A., MURPHY, K. M., ATKINSON, J. P. (2003). Activation of human CD4+ cells with CD3 and CD46 induces a T-regulatory cell 1 phenotype. Nature, 421(6921): 388-392.

KHAJOEE, V., IHARA, K., KIRA, R., TAKEMOTO, M., TORISU, H., SAKAI, Y., GUANJUN,, J., HEE, P. M., TOKUNAGA, K., HARA, T. (2003). Founder effect of the C9 R95X mutation in Orientals. Hum Genet, 112(3): 244-248.

KIM, D. D., SONG, W. C. (2006). Membrane complement regulatory proteins. Clin Immunol, 118(23): 127-136.

KIRA, R., IHARA, K., TAKADA, H., GONDO, K., HARA, T. (1998). Nonsense mutation in exon 4 of human complement C9 gene is the major cause of Japanese complement C9 deficiency. Hum Genet, 102(6): 605-10.

KIRKITADZE, M.D. \& BARLOW, P. N. (2001). Structure and flexibility of the multiple domain proteins that regulate complement activation. Immunological reviews, 180: 146-161. 
KLEIN, R. B.; KLEIN, B.; LINTON, K. (1992). Prevalence of age-related maculopathy: The Beaver Dam Study. Ophthalmol, 99: 933-943.

KLEIN, R.J.; ZEISS, C.; CHEW, E.Y.; TSAI, J-T.; SACKLER, R.S.; HAYNES, C.; HENNING, A.K.; SANGIOVANNI, J.P.; MANE, S.M.; MAYNE, S.T.; BRACKEN, M.B.; FERRIS, F.L.; OTT, J.; BARNSTABLE, C. \& HOH, J. (2005). Complement Factor H polymorphism in age-related macular degeneration._Sciences, 308: 385-389.

KÖHL, J. (2006). The role of complement in danger sensing and transmission. Immunol Res, 34(2): 157-176.

KOTARSKY, H., HELLWAGE, J., JOHNSSON, E., SKERKA, C., SVENSSON, H. G., LINDAHL, G., SJOBRING, U., ZIPFEL, P. F. (1998). Identification of a domain in human factor $\mathrm{H}$ and factor Hlike protein-1 required for the interaction with streptococcal M proteins. J Immunol, 160(7): 33493354.

KRAICZY, P., WURZNER, R. (2006). Complement escape of human pathogenic bacteria by acquisition of complement regulators. Mol Immunol, 43(1-2): 31-44.

KUHN, S., SKERKA, C., ZIPFEL, P. F. (1995). Mapping of the complement regulatory domains in the human factor H-like protein 1 and in factor H1. J Immunol, 155(12): 5663-5670.

KUHN, S., ZIPFEL, P. F. (1996). Mapping of the domains required for decay acceleration activity of the human factor H-like protein 1 and factor H. Eur J Immunol, 26(10): 2383-7.

LAMBRIS, J. D., MULLER-EBERHARD, H. J. (1986). The multifunctional role of C3: structural analysis of its interactions with physiological ligands. Mol Immunol, 23(11): 1237-1242.

LAMBRIS, J. D., REID, K. B. M. \& VOLANAKIS, J. E. (1999). The evolution, structure, biology and pathophysiology of complement 1. Trends in Immunology Today, 38(5): 207-211.

LENGWEILER, S., SCHALLER, J., RICKLI, E. (1996). Identification of disulfide bonds in the ninth component (C9) of human complement. FEBS Lett, 380(1-2): 8-12. 
LEHTO, T., HONKANEN, E., TEPPO, A. M., MERI, S. (1995). Urinary excretion of protectin (CD59), complement SC5b-9 and cytokines in membranous glomerulonephritis. Kidney Int, 47(5): 1403-11.

LEVY, M., HALBWACHS-MECARELLI, L., GUBLER, M. C., KOHOUT, G., BENSENOUCI, A., NIAUDET, P., HAUPTMANN, G., LESAVRE, P. (1986). H deficiency in two brothers with atypical dense intramembranous deposit disease. Kidney Int, 30(6): 949-956.

LICHTENHELD, M. G., OLSEN, K. J., LU, P., LOWREY, D. M., HAMEED, A., HENGARTNER, H., PODACK, E R. (1988). Structure and function of human perforin. Nature, 335(6189): 448-51.

LINTON, S. M., MORGAN, B. P. (1999). Properdin deficiency and meningococcal disease-identifying those most at risk. Clin Exp Immunol, 118(2): 189-91.

LISZEWSKI, M. K., FARRIES, T. C., LUBLIN, D. M., ROONEY, I. A., ATKINSON, J. P. (1996). Control of the complement system. Adv Immunol, 61: 201-83.

LOPEZ-LARREA, C., DIEGEZ, M. A., ENGUIX, A., DOMÍNGUEZ, O., MARIN, B., GOMEZ, E. (1987). A family deficiency of complement factor H. Biochem Soc Trans, 15: 648-649.

LU, J. H., THIEL, S., WIEDEMANN, H., TIMPL, R., REID, K. B. (1990). Binding of the pentamer/hexamer forms of mannan-binding protein to zymosan activates the proenzyme C1r2C1s2 complex, of the classical pathway of complement, without involvement of C1q. J Immunol, 144(6): 2287-94.

LUBLIN, D. M., ATKINSON, J. P. (1989). Decay-accelerating factor: biochemistry, molecular biology, and function. Annu Rev Immunol, 7: 35-58.

MANCINI, G., CARBONARA, A. O., HEREMANS, J. F. (1965). Immunochemical quantitation of antigens by single radial immunodiffusion. Immunochemistry. 2(3): 235-54.

MANUELIAN, T., HELLWAGE, J., MERI, S., CAPRIOLI, J., NORIS, M., HEINEN, S., JOZSI, M, NEUMANN, H. P., REMUZZI, G., ZIPFEL, P. F. (2003). Mutations in factor H reduce binding affinity to $\mathrm{C} 3 \mathrm{~b}$ and heparin and surface attachment to endothelial cells in hemolytic uremic syndrome. J Clin Invest, 111(8): 1181-90.

MATSUSHITA, M., FUJITA, T. (1992). Activation of the classical complement pathway by mannose-binding protein in association with a novel C1s-like serine protease. J Exp Med, 176(6): 1497-502.

MATSUSHITA, M., ENDO, Y., FUJITA, T. (2000). Cutting edge: complement-activating complex of ficolin and mannose-binding lectin-associated serine protease. J Immunol, 164(5): 2281-4. 
MAYER, M. M. (1973). The complement system. Scientific American, 229(5): 54-66.

MCRAE, J. L., DUTHY, T. G., GRIGGS, K. M., ORMSBY, R. J., COWAN, P. J., CROMER, B. A., MCKINSTRY, W. J., PARKER, M. W., MURPHY, B. F., GORDON, D. L. (2005). Human factor Hrelated protein 5 has cofactor activity, inhibits C3 convertase activity, binds heparin and C-reactive protein, and associates with lipoprotein. J Immunol, 174: 6250-6256.

MEDICUS, R. G., SCHREIBER, R. D., GOTZE, O. MULLER-EBERHARD, H. J. (1976). A molecular concept of the properdin pathway. Proc Natl Acad Sci, 73(2): 612-616.

MERI, S., KOISTINEN, V., MIETTINEN, A., TORNROTH, T., SEPPALA, I. J. (1992). Activation of the alternative pathway of complement by monoclonal lambda light chains in membranoproliferative glomerulonephritis. J Exp Med, 175(4): 939-50.

MOLLNES, T. E., SONG, W. C., LAMBRIS, J. D. (2002). Complement in inflammatory tissue damage and disease. Trends Immunol, 23(2): 61-64.

MORGAN, B. P., WALPORT, M. J. (1991). Complement deficiency and disease. Immunol Today, 12(9): 301-6.

MORGAN, B. P. \& HARRIS, C. L. (1999). Complement regulatory proteins, eds, Academic Press, London.

MORLEY, B. J. \& WALPORT, M. J. (2000). The complement facts book, eds, Academic Press, London.

MÜLLER-EBERHARD, H. J. (1986). The membrane attack complex of complement. Annu Rev Immunol, 4: 503-28.

NAKED, G. M., FLORIDO, M. P., FERREIRA DE PAULA, P., VINET, A. M., INOSTROZA, J. S., ISAAC, L. (2000). Deficiency of human complement factor I associated with lowered factor H. Clin Immunol, 96(2): 162-7. 
NANGAKU, M. (1998). Complement regulatory proteins in glomerular diseases. Kidney Int, 54(5): 1419-28.

NAGATA, M., HARA, T., AOKI, T., MIZUNO, Y., AKEDA, H., INABA, S., TSUMOTO, K., UEDA, K. (1989). Inherited deficiency of ninth component of complement: an increased risk of meningococcal meningitis. J Pediatr, 114(2): 260-4.

NEUMANN, H. P., SALZMANN, M., BOHNERT-IWAN, B., MANNUELIAN, T., SKERKA, C., LENK, D., BENDER, B. U., CYBULLA, M., RIEGLER, P., KONIGSRAINER, A., NEYER, U., BOCK, A., WIDMER, U., MALE, D. A., FRANKE, G., ZIPFEL, P. F. (2003). Haemolytic uraemic syndrome and mutations of the factor $\mathrm{H}$ gene: a registry-based study of German speaking countries. $\mathbf{J}$ Med Genet, 40(9): 676-81.

NICHOLSON-WELLER, A., WANG, C. E. (1994). Structure and function of decay accelerating factor CD55. J Lab Clin Med, 123(4): 485-91.

NIELSEN, H., KOCH, K. (1987). Anti-inflammatory action of fenflumizole in man: suppression of monocyte chemotaxis ex vivo. Pharmacol Toxicol, 60(5): 397-8.

NIELSEN, H. E., CHRISTENSEN, K. C., KOCH, C., THOMSEN, B. S., HEEGAARD, N. H., TRANUM-JENSEN, J. (1989). Hereditary, complete deficiency of complement factor H associated with recurrent meningococcal disease. Scand J Immunol, 30(6): 711-8.

NILSSON, U. R., MUELLER-EBERHARD, H. J. (1965). Isolation of beta IF-Globulin from human serum and its characterization as the fifth component of complement. J Exp Med, 122: 277-98.

NILSSON, U. R. \& NILSSON, B. (1984). Simplified assays of hemolytic activity of the classical and alternative complement pathways. J Immunol Methods, 72: 49-59.

NORIS, M., BRIOSCHI, S., CAPRIOLI, J., TODESCHINI, M., BRESIN, E., PORRATI, F., GAMBA, S., REMUZZI, G. (2003). International Registry of Recurrent and Familial HUS/TTP. Familial haemolytic uraemic syndrome and an MCP mutation. Lancet, 362(9395): 1542-7.

OHALI, M., SHALEV, H., SCHLESINGER, M., KATZ, Y., KACHKO, L., CARMI, R., SOFER, S., LANDAU, D. (1998). Hypocomplementemic autosomal recessive hemolytic uremic syndrome with decreased factor H. Pediatr Nephrol, 12(8): 619-24.

OUCHTERLONY, O. AND NILSSON, L. Immunodiffusion and immunoelectrophoresis. In: Weir, D.

M. ed. Handbook of experimental immunology, $3^{\text {a }}$ ed. Blackwell, Oxford. Cap.19, p. 19.1-19.44. 
OHTA, M., OKADA, M., YAMASHINA, I., KAWASAKI, T. (1990). The mechanism of carbohydrate-mediated complement activation by the serum mannan-binding protein. J Biol Chem, 265(4): 1980-4.

ORMSBY, R. J., JOKIRANTA, T. S., DUTHY, T. G., GRIGGS, K. M., SADLON, T. A., GIANNAKIS, E., GORDON, D. L. (2006). Localization of the third heparin-binding site in the human complement regulator factor H1. Mol Immunol, 43(10): 1624-1632.

ORREN, A., O'HARA, A. M., MORGAN, B. P., MORAN, A. P., WURZNER, R. (2003). An abnormal but functionally active complement component $\mathrm{C} 9$ protein found in an Irish family with subtotal C9 deficiency. Immunology, 108(3): 384-90.

PANGBURN, M. K. \& MÜLLER-EBERHARD H. J. (1983a). Initiation of the alternative complement pathway due to spontaneous hydrolysis of the thioester of C3. Annals New York Academy of Sciences, 421: 291-298.

PANGBURN, M. K. (1983b). Activation of complement via the alternative pathway. Federation Proceedings, 42(1): 139-143.

PANGBURN, M. K. \& MÜLLER-EBERHARD, H. J. (1984). The alternative pathway of complement. Springer Seminars in Immunopathology, 7: 163-192.

PANGBURN, M. K., ATKINSON, M. A., MERI, S. (1991). Localization of the heparin-binding site on complement factor H. J Biol Chem, 266(25): 16847-16853.

PAPPALARDO, E., ZINGALE, L. C., TERLIZZI, A., ZANICHELLI, A., FOLCIONI, A., CICARDI, M. (2002). Mechanisms of C1-inhibitor deficiency. Immunobiology, 205(4-5): 542-51.

PEREZ-CABALlERO, D., GONZALEZ-RUBIO, C., GALLARDO, M. E., VERA, M., LOPEZTRASCASA, M., RODRIGUEZ DE CORDOBA, S., SANCHEZ-CORRAL, P. (2001). Clustering of missense mutations in the $\mathrm{C}$-terminal region of factor $\mathrm{H}$ in atypical hemolytic uremic syndrome. Am $\mathbf{J}$ Hum Genet, 68(2): 478-84.

PERKINS, S. J., GOODSHIP, T. H. (2002). Molecular modelling of the C-terminal domains of factor $\mathrm{H}$ of human complement: a correlation between haemolytic uraemic syndrome and a predicted heparin binding site. J Mol Biol, 316(2): 217-224. 
PERRY, R. P., LA TORRE, J., KELLEY, D. E., GREENBERG, J. R. On the lability of poly(A) sequences during extraction of messenger RNA from polyribosomes. Biochim Biophys Acta, 262: 220.

PICHETTE, V., QUERIN, S., SCHURCH, W., BRUN, G., LEHNER-NETSCH, G., DELAGE, J. M. Familial hemolytic-uremic syndrome and homozygous factor H deficiency. Am J Kidney Dis, 24(6): 936-941.

PICKERING, M. C., BOTTO, M., TAYLOR, P. R., LACHMANN, P. J., WALPORT, M. J. (2000). Systemic lupus erythematosus, complement deficiency, and apoptosis. Adv Immunol, 76: 227-324.

PODACK, E. R., KOLB, W. P., MULLER-EBERHARD, H. J. (1977). The SC5b-7 complex: formation, isolation, properties, and subunit composition. J Immunol, 119(6): 2024-9.

PODACK, E. R. (1984). Molecular composition of the tubular structure of the membrane attack complex of complement. J Biol Chem, 259(13): 8641-7.

PRODINGER, W. M., HELlWAGE, J., SPRUTH, M., DIERICH, M. P., ZIPFEL, P. F. (1998). The $\mathrm{C}$-terminus of factor $\mathrm{H}$ : monoclonal antibodies inhibit heparin binding and identify epitopes common to factor $\mathrm{H}$ and factor H-related proteins. Biochem J, 331(1): 41-7.

REIS, E. S, FALCAO, D. A., ISAAC, L. (2006). Clinical aspects and molecular basis of primary deficiencies of complement component $\mathrm{C} 3$ and its regulatory proteins factor I and factor H. Scand $\mathbf{J}$ Immunol, 63(3): 155-68.

RICHARDS, A., BUDDLES, M. R., DONNE, R. L., KAPLAN, B. S., KIRK, E., VENNING, M. C., TIELEMANS, C. L., GOODSHIP, J. A., GOODSHIP, T. H. (2001). Factor H mutations in hemolytic uremic syndrome cluster in exons 18-20, a domain important for host cell recognition. Am J Hum Genet, 68(2): 485-90.

RICHARDS, A., GOODSHIP, J. A., GOODSHIP, T. H. (2002). The genetics and pathogenesis of haemolytic uraemic syndrome and thrombotic thrombocytopenic purpura. Curr Opin Nephrol Hypertens, 11(4): 431-5.

RICHARDS, A., KATHRYN LISZEWSKI, M., KAVANAGH, D., FANG, C. J., MOULTON, E., FREMEAUX-BACCHI, V., REMUZZI, G., NORIS, M., GOODSHIP, T. H., ATKINSON, J. P. (2007). Implications of the initial mutations in membrane cofactor protein (MCP; CD46) leading to atypical hemolytic uremic syndrome. Mol Immunol, 44(1-3): 111-22.

RILEY-VARGAS, R. C., GILL, D. B., KEMPER, C., LISZEWSKI, M. K., ATKINSON, J. P. (2004). CD46: expanding beyond complement regulation. Trends Immunol, 25(9): 496-503. 
RIPOCHE J, DAY AJ, HARRIS TJ, SIM RB. (1988). The complete amino acid sequence of human complement factor H. Biochem J, 249(2): 593-602.

RITCHIE, R. F., PALOMAKI, G. E., NEVUX, L. M., NAVOLOTSKAIA, O., LEDUE, T. P. CRAIG, W. Y. (2003). Reference distributions of complement proteins C3 and C4: a practical, simple and clinically relevant approach in a large cohort. Clin Lab Anal, 16: 1-5.

RODRIGUEZ DE CORDOBA, S., ESPARZA-GORDILLO, J., GOICOECHEA DE JORGE, E., LOPEZ-TRASCASA, M., SANCHEZ-CORRAL, P. (2004). The human complement factor H: functional roles, genetic variations anddisease associations. Mol Immunol, 41(4): 355-367.

ROOS, A., BOUWMAN, L. H., VAN GIJLSWIJK-JANSSEN, D. J., FABER-KROL, M. C., STAHL, G. L., DAHA, M. R. (2001). Human IgA activates the complement system via the mannan-biding lectin pathway. The Journal of Immunology, 167: 2861-2868.

ROSENFELD, S. I., BAUM, J., STEIGBIGEL, R. T., LEDDY, J. P. (1976). Hereditary deficiency of the fifth component of complement in man. II. Biological properties of C5-deficient human serum. $\mathbf{J}$ Clin Invest, 57(6): 1635-1643.

ROUGIER, N., KAZATCHKINE, M. D., ROUGIER, J. P., FREMEAUX-BACCHI, V., BLOUIN, J., DESCHENES, G., SOTO, B., BAUDOUIN, V., PAUTARD, B., PROESMANS, W., WEISS, E., WEISS, L. (1998). Human complement factor $\mathrm{H}$ deficiency associated with hemolytic uremic syndrome. J Am Soc Nephrol, 9(12): 2318-2326.

SANCHEZ-CORRAL, P., BELLAVIA, D., AMICO, L., BRAI, M., RODRIGUEZ DE CORDOBA, S. (2000). Molecular basis for factor H and FHL-1 deficiency in an Italian family. Immunogenetics, 51(4-5): 366-369.

SANCHEZ-CORRAL, P., PEREZ-CABALlERO, D., HUARTE, O., SIMCKES, A. M., GOICOECHEA, E., LOPEZ-TRASCASA, M., DE CORDOBA, S. R. (2002). Structural and functional characterization of factor $\mathrm{H}$ mutations associated with atypical hemolytic uremic syndrome. Am J Hum Genet, 71(6), Dec, p. 1285-1295.

SAUNDERS, R. E., GOODSHIP, T. H., ZIPFEL, P. F., PERKINS, S. J. (2006). An interactive web database of factor $\mathrm{H}$-associated hemolytic uremic syndrome mutations: insights into the structural consequences of disease-associated mutations. Hum Mutat, 27(1): 21-30.

SCHMIDT, B. Z., FOWLER, N. L., HIDVEGI, T., PERLMUTTER, D. H., COLTEN, H. R. (1999). Disruption of disulfide bonds is responsible for impaired secretion in human complement factor $\mathrm{H}$ deficiency. J Biol Chem, 274(17): 11782-11788. 
SCHNORR, J. J., DUNSTER, L. M., NANAN, R., SCHNEIDER-SCHAULIES, J., SCHNEIDERSCHAULIES, S., TER MEULEN, V. (1995). Measles virus-induced down-regulation of CD46 is associated with enhanced sensitivity to complement-mediated lysis of infected cells. Eur J Immunol, 25(4): 976-984.

SHARMA, A. K., PANGBURN, M. K. (1996). Identification of three physically and functionally distinct binding sites for $\mathrm{C} 3 \mathrm{~b}$ in human complement factor $\mathrm{H}$ by deletion mutagenesis. Proc Natl Acad Sci U S A, 93(20): 10996-11001.

SCHIFFERLI, J., MIOT, S. (2000). Factor D. In: The complement facts book, eds. B. J. Morley \& M. J. Walport, p. 69-72.

SHINKAI, Y., TAKIO, K., OKUMURA, K. (1988). Homology of perforin to the ninth component of complement (C9). Nature, 334(6182): 525-7.

SCHWAEBLE, W., ZWIRNER, J., ACHULZ, T. F., LINKE, R. P., DIERICH, M. P., WEISS, E. H. (1987). Human complement factor $\mathrm{H}$ : expression of an additional truncated gene product of $43 \mathrm{kDa}$ in human liver. European Journal of Immunology, 17: 1485-1489.

SILVERSTEIN, A. M. (1989). A history of immunology, eds, Academic Pres, London.

SIM, R. B., ARLAUD, G. J., COLOMB, M. G. (1979). C1 inhibitor-dependent dissociation of human complement component C1 bound to immune complexes. Biochem J, 179(3): 449-57.

SIM, R. B., DISCIPIO, R. G. (1982). Purification and structural studies on the complement-system control protein beta 1H (Factor H). Biochem J, .205, n.2, Aug, p. 285-93.

SIM, R. B., KOLBLE, K., MCALEER, M. A., DOMINGUEZ, O., DEE, V. M. (1993). Genetics and deficiencies of the soluble regulatory proteins of the complement system. Int Rev Immunol, 10(1): 65-86.

SJOHOLM, A. G., BRACONIER, J. H., SODERSTROM, C. (1982). Properdin deficiency in a family with fulminant meningococcal infections. Clin Exp Immunol, 50(2): 291-7.

SKERKA, C., HORSTMANN, R. D., ZIPFEL, P. F. (1991). Molecular cloning of a human serum protein structurally related to complement factor H. J Biol Chem, 266(18): 12015-20. 
SKERKA, C., TIMMANN, C., HORSTMANN, R. D., ZIPFEL, P. F. (1992). Two additional human serum proteins structurally related to complement factor $\mathrm{H}$. Evidence for a family of factor $\mathrm{H}$-related genes. J Immunol, 148(10): 3313-3318.

SKERKA, C., KUHN, S., GUNTHER, K., LINGELBACH, K., ZIPFEL, P. F. (1993). A novel short consensus repeat-containing molecule is related to human complement factor H. J Biol Chem, 268(4): 2904-8.

SNYDERMAN, R., DURACK, D. T., MCCARTY, G. A., WARD, F. E., MEADOWS, L. (1979). Deficiency of the fifth component of complement in human subjects. Clinical, genetic and immunologic studies in a large kindred. Am J Med, 67(4): 638-45.

SOHN, J-H.; KAPLAN, H.J.; SUK, H-J; BORA, O.S.; BORA, N.S. (2000). Complement regulatory activity of normal human intraocular fluid is mediated by MCP, DAF and CD59. Investigative Ophthalmology \& Visual Science, 41(13): 4195-4202.

SOUIED, E.H.; LEVEZIEL, N.; RICHARD, F.; DRAGON-DUREY, M-A., COSCAS, G.; SOUBRANE, G.; BENLIAN, P.; FREMEAUX-BACCHI, V. (2005). Y402H Complement Factor H polymorphism associated with exsudative age-related degeneration in the French population. Molecular Vision, 11: 1135-1140.

SPRONG, T., BRANDTZAEG, P., FUNG, M., PHARO A. M., HOIBY E. A., MICHAELSEN T. E., AASE A., VAN DER MEER J. W., VAN DEUREN M., MOLLNES, T. E. (2003). Inhibition of C5ainduced inflammation with preserved C5b-9-mediated bactericidal activity in a human whole blood model of meningococcal sepsis. Blood, 102(10): 3702-3710.

STANLEY, K. K., KOCHER, H. P., LUZIO, J. P., JACKSON, P., TSCHOPP, J. (1985). The sequence and topology of human complement component C9. EMBO J, 4(2): 375-382.

STOVER, C. M., THIEL, S., THELEN, M., LYNCH, N. J., VORUP-JENSEN, T., JENSENIUS, J. C., SCHWAEBLE, W. J. (1999) .Two constituents of the initiation complex of the mannan-binding lectin activation pathway of complement are encoded by a single structural gene. J Immunol, 162: 34813490. 
TANDON, N., MORGAN, B. P., WEETMAN, A. P. (1992). Expression and function of membrane attack complex inhibitory proteins on thyroid follicular cells. Immunology, 75(2): 372-377.

TAYLOR, C. M. (2001). Complement factor $\mathrm{H}$ and the haemolytic uraemic syndrome. Lancet, 358(9289): 1200-1202.

THOMPSON, R. A., WINTERBORN, M. H. (1981). Hypocomplementaemia due to a genetic deficiency of beta 1H globulin. Clin Exp Immunol, 46(1): 110-119.

TRUEDSSON, L., WESTBERG, J., FREDRIKSON, G. N., SJOHOLM, A. G., KUIJPER, E. J., FIJEN, C. A.,SPATH, P. J., UHLEN, M. (1997). Human properdin deficiency has a heterogeneous genetic background. Immunopharmacology, 38(1-2): 203-206.

TSCHOPP, J., PODACK, E. R., MULLER-EBERHARD, H. J. (1985). The membrane attack complex of complement: C5b-8 complex as accelerator of C9 polymerization. J Immunol, 134(1): 495-499.

TURNER, M. W. (1996). Mannose-binding lectin: the pluripotent molecule of the innate immune system. Review in Immunology Today, 17(11): 532-540.

ULBRICH, A. G., FLORIDO, M. P., NUDELMAN, V., REIS, E. S., BARACHO, G. V., ISAAC, L. (2001). Hereditary human complement C3 deficiency owing to reduced levels of C3 mRNA. Scand J Immunol, 53(6): 622-626.

VOGT, B. A., WYATT, R. J., BURKE, B. A., SIMONTON, S. C., KASHTAN, C. E. (1995). Inherited factor H deficiency and collagen type III glomerulopathy. Pediatr Nephrol, 9(1): 11-5.

VYSE, T. J., SPATH, P. J., DAVIES, K. A., MORLEY, B. J., PHILIPPE, P., ATHANASSIOU, P., GILES, C. M., WALPORT, M. J. (1994). Hereditary complement factor I deficiency. QJM, 87(7): $385-401$.

VYSE, T. J., MORLEY, B. J., BARTOK, I., THEODORIDIS, E. L., DAVIES, K. A., WEBSTER, A. D., WALPORT, M. J. (1996). The molecular basis of hereditary complement factor I deficiency. J Clin Invest, 97(4): 925-33.

WALPORT, M. J. (2001). Complement. First of two parts. N Engl J Med, 344(14): 1058-66.

WARWICKER, P., GOODSHIP, T. H., DONNE, R. L., PIRSON, Y., NICHOLLS, A., WARD, R. M., TURNPENNY, P., GOODSHIP, J. A. (1998). Genetic studies into inherited and sporadic hemolytic uremic syndrome. Kidney Int, 53(4), Apr, p. 836-44. 
WEILER, J. M., DAHA, M. R., AUSTEN, K. F., FEARON, D. T. (1976). Control of the amplification convertase of complement by the plasma protein beta1H. Proc Natl Acad Sci U S A., 73(9): 3268-72.

WEST, C. D. (1994). Nephritic factors predispose to chronic glomerulonephritis. Am J Kidney Dis, 24(6): 956-63.

WITZEL-SCHLOMP, K., SPATH, P. J., HOBART, M. J., FERNIE, B. A., RITTNER, C., KAUFMANN, T., SCHNEIDER, P. M. (1997). The human complement C9 gene: identification of two mutations causing deficiency and revision of the gene structure. J Immunol, 158(10): 5043-9.

WITZEL-SCHLOMP, K., HOBART, M. J., FERNIE, B. A., ORREN, A., WURZNER, R., RITTNER, C., KAUFMANN, T., SCHNEIDER, P. M. (1998). Heterogeneity in the genetic basis of human complement C9 deficiency. Immunogenetics, 48(2): 144-7.

WITZEL-SCHLOMP, K., RITTNER, C., SCHNEIDER, P. M. (2001). The human complement C9 gene: structural analysis of the $5^{\prime}$ gene region and genetic polymorphism studies. Eur J Immunogenet, 28(5): 515-22.

YING, L., KATZ, Y., SCHLESINGER, M., CARMI, R., SHALEV, H., HAIDER, N., BECK, G., SHEFFIELD, V. C., LANDAU, D. (1999). Complement factor H gene mutation associated with autosomal recessive atypical hemolytic uremic syndrome. Am J Hum Genet, 65(6): 1538-46.

YOUNG, J. D., COHN, Z. A., PODACK, E. R. (1986). The ninth component of complement and the pore-forming protein (perforin 1) from cytotoxic $\mathrm{T}$ cells: structural, immunological, and functional similarities. Science, 233(4760): 184-90.

ZICCARDI, R. J. (1983). The first component of human complement (C1): activation and control. Springer Semin Immunopathol, 6(2-3): 213-30.

ZIPFEL, P. F. \& SKERKA, C. (1994). Complement factor H and related proteins: an expanding family of complement-regulatory proteins? Immunology Today, 15(3): 121-126.

ZIPFEL, P. F., SKERKA, C. (1999). FHL-1/reconectin: a human complement and immune regulator with cell-adhesive function. Immunol Today, 20(3): 135-40.

ZIPFEL, P. F., JOKIRANTA, T. S., HELLWAGE, J., KOISTINEM, V., MERI, S. (1999a). The factor H protein family. Immunopharmacology, 42: 53-60. 
ZIPFEL, P. F., HELlWAGE, J., FRIESE, M. A., HEGASY, G., JOKIRANTA, S. T., MERI, S. (1999b). Factor H and disease: a complement regulator affects vital body functions. Mol Immunol, 36(4-5): 241-8.

ZIPFEL, P. F. (2001). Hemolytic uremic syndrome: how do factor $\mathrm{H}$ mutants mediate endothelial damage? Trends Immunol, 22(7): 345-348.

ZIPFEL, P. F., SKERKA, C., CAPRIOLI, J., MANUELIAN, T., NEUMANN, H. H., NORIS, M., REMUZZI, G. (2001). Complement factor $\mathrm{H}$ and hemolytic uremic syndrome. International Immunopharmacology, 1: 461-468.

ZIPFEL, P. F., SKERKA, C., HELlWAGE, J., JOKIRANTA, S. T., MERI, S., BRADE, V., KRAICZY, P., NORIS, M., REMUZZI, G. (2002). Factor H family proteins: on complement, microbes and human diseases. Biochem Soc Trans, 30(6): 971-978.

ZIPFEL, P. F., SKERKA, C. (2006). Complement dysfunction in hemolytic uremic syndrome. Curr Opin Rheumatol, 18(5): 548-555.

ZIPFEL, P. F., HEINEN, S., JOZSI, M., SKERKA, C. (2006). Complement and diseases: defective alternative pathway control results in kidney and eye diseases. Mol Immunol. 43(1-2): 97-106. 